\title{
Strategije in uspešnost podjetja
}

Dušan Gošnik

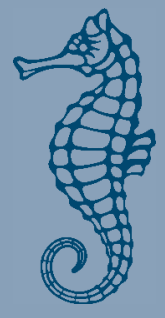


University of Primorska Press

Editorial Board

Gregor Pobežin

Maja Meško

Vito Vitrih

Silva Bratož

Aleksandra Brezovec

Ana Petelin

Janko Gravner

Krstivoje Špijunović

Miloš Zelenka

Jonatan Vinkler

Alen Ježovnik

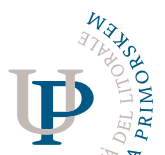

UNIVERT 


\section{Strategije in uspešnost podjetja}

Dušan Gošnik

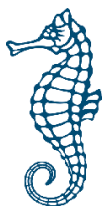




\section{Strategije in uspešnost podjetja}

Dušan Gošnik

Recenzenta . Cene Bavec in Aljaž Stare

Lektora in prelom Davorin Dukič

Izdala in založila . Založba Univerze na Primorskem

Titov trg 4, Koper · www.hippocampus.si

Glavni urednik . Jonatan Vinkler

Vodja založbe . Alen Ježovnik

(C) 2020 Univerza na Primorskem

Koper, december 2020

http://www.hippocampus.si/ISBN/978-96I-293-03I-8.pdf

http://www.hippocampus.si/ISBN/978-96I-293-032-5/index.html

https://doi.org/I0.26493/978-96I-293-03I-8

Izid monografije je finančno podprla Javna agencija

za raziskovalno dejavnost Republike Slovenije iz sredstev

državnega proračuna iz naslova razpisa

za sofinanciranje znanstvenih monografij

\section{(cc) BY-SA}

Kataložni zapis o publikaciji (CıP) pripravili

v Narodni in univerzitetni knjižnici v Ljubljani

COBISS.SI-ID $=54 \mathrm{I} 486 \mathrm{II}$

ISBN 978-96I-293-03I-8 (pdf)

ISBN 978-96I-293-032-5 (html) 


\section{Vsebina}

\section{Slike in preglednice}

\section{Kratice}

15 Uvod

I6 Izhodišča in opis ožjega znanstvenega področja raziskovanja

I6 Opredelitev raziskovalnega problema

I8 Namen in cilji raziskave

I8 Predstavitev temeljne hipoteze raziskave

I9 Uporabljene metode raziskovanja

20 Omejitve in predpostavke raziskovanja

25 Opredelitev uspešnosti podjetja

25 Okolje, strategije in uspešnost podjetja

27 Zunanje okolje in uspešnost podjetja

27 Kupci

27 Konkurenti

28 Tehnologija

29 Dobavitelji

3 I Strategija podjetja do kupcev in uspešnost podjetja

3I Strategija diferenciacije

32 Strategija nizkih stroškov in privlačnih cen

32 Strategija osredinjenja

33 Strategija prehitevanja

35 Teoretični model povezav, hipoteza in merski instrument

35 Predstavitev modela raziskave

37 Hipoteza in merski instrument 
37 Spremembevokolju

39 Strategija podjetja do kupcev

40 Uspešnost podjetja

42 Način potrjevanja hipoteze

45 Rezultati empirične raziskave

45 Opis poteka zbiranja in analize podatkov

45 Opis ciljne populacije

46 Uporabljene metode zbiranja podatkov

47 Testiranje veljavnosti in zanesljivosti merskega instrumenta

48 Vzorec anketiranih podjetij

48 Uporabljene metode analize podatkov

49 Opisna statistika rezultatov raziskave

50 Rezultati analize vzorca podjetij

52 Rezultati ocen za dejavnik »Spremembe v okolju «

56 Rezultati ocen za dejavnik »Strategija podjetja do kupcev«

6I Rezultati ocen o uspešnosti anketiranih podjetij

62 Preverjanje teoretičnega modela za dejavnik »Spremembe v okolju«

62 Rezultati ocen na področju $\gg$ Kupci «

64 Rezultati ocen na področju »Konkurenti«

67 Rezultati ocen na področju »Tehnologija «

69 Rezultati ocen na področju »Dobavitelji $\ll$

72 Preverjanje teoretičnega modela za dejavnik »Strategija podjetja do kupcev «

73 Rezultati ocen na področju »Strategija diferenciacije «

76 Rezultati ocen na področju »Strategija nizkih stroškov in privlačnih cen «

78 Rezultati ocen na področju »Strategija osredinjenja «

8I Rezultati ocen na področju »Strategija prehitevanja «

85 Povzetek ugotovitev raziskave

85 Povzetek o preverjanju zastavljenega modela in interpretacija rezultatov

88 Povzetek ugotovitev preverjanja zastavljene hipoteze

9I Sklep

9I Poročilo o doseganju ciljev raziskave

92 Implikacije za večjo uspešnost podjetij v praksi

95 Priloga I: Anketni vprašalnik

IOI Priloga 2: Opisna statistika za dejavnik »Spremembe v okolju «

IO5 Priloga 3: Opisna statistika za dejavnik »Strategija podjetja do kupcev $\ll$

Io9 Priloga 4: Opisna statistika za uspešnost podjetja

II3 Priloga 5: Rezultati modeliranja s strukturnimi modeli 
I2I Priloga 6: Vrednosti Cronbachovih koeficientov alfa ( $\alpha$ )

I23 Povzetek

127 Summary

I3I Literatura

I43 Recenziji

143 I

144 II 



\section{Slike in preglednice}

36 Slika ı: Teoretični model povezav

86 Slika 2: Model strukturnih enačb pri preverjanju hipoteze

50 Preglednica I: Panoga, v kateri posluje podjetje

5I Preglednica 2: Povprečno število zaposlenih

5I Preglednica 3: Dosežena najvišja stopnja izobrazbe anketiranca

52 Preglednica 4: Trenutna funkcija anketiranca v podjetju

53 Preglednica 5: Rezultati ocen za dejavnik »Spremembe v okolju «- področje $\gg$ Kupci $\ll$

54 Preglednica 6: Rezultati ocen za dejavnik »Spremembe v okolju «-področje $\gg$ Konkurenti $\ll$

55 Preglednica 7: Rezultati ocen za dejavnik »Spremembe v okolju «-področje $\gg$ Tehnologija «

56 Preglednica 8: Rezultati ocen za dejavnik »Spremembe v okolju «-področje $\gg$ Dobavitelji $\ll$

57 Preglednica 9: Rezultati ocen za dejavnik »Strategija podjetja do kupcev« - področje » Strategija diferenciacije «

58 Preglednica Io: Rezultati ocen za dejavnik »Strategija podjetja do kupcev «področje »Strategija nizkih stroškov in privlačnih cen «

59 Preglednica Ir: Rezultati ocen za dejavnik »Strategija podjetja do kupcev« - področje » Strategija osredinjenja «

60 Preglednica I2: Rezultati ocen za dejavnik »Strategija podjetja do kupcev« - področje » Strategija prehitevanja $\ll$

6I Preglednica I3: Uspešnost podjetja glede na glavnega tekmeca v panogi

62 Preglednica I4: Izid ocene uspešnosti podjetja glede na glavnega tekmeca v panogi 
63 Preglednica I5: Področje $\gg$ Kupci « - povezanost med trditvami

64 Preglednica I6: Področje $»$ Konkurenti « - povezanost med trditvami

65 Preglednica 17: Področje $»$ Konkurenti $\ll-K M O$ in Bartlettov test

65 Preglednica I8: Področje $»$ Konkurenti $\ll-$ komunalitete

66 Preglednica 19: Področje »Konkurenti $\ll$ - celotna pojasnjena varianca

66 Preglednica 20: Področje »Konkurenti « - matrika faktorskih uteži

67 Preglednica 2r: Področje $\gg$ Tehnologija « - povezanost med trditvami

68 Preglednica 22: Področje »Tehnologija « - KMO in Bartlettov test

68 Preglednica 23: Področje »Tehnologija « - komunalitete

69 Preglednica 24: Področje $\gg$ Tehnologija $«$ - celotna pojasnjena varianca

69 Preglednica 25: Področje »Tehnologija « - matrika faktorskih uteži

70 Preglednica 26: Področje »Dobavitelji $\ll-$ povezanost med trditvami

7I Preglednica 27: Področje »Dobavitelji $\ll-\mathrm{KMO}$ in Bartlettov test

7I Preglednica 28: Področje »Dobavitelji $\ll-$ komunalitete

7I Preglednica 29: Področje »Dobavitelji $\ll$ - celotna pojasnjena varianca

72 Preglednica 30: Področje »Dobavitelji « - matrika faktorskih uteži

74 Preglednica 3i: Področje »Strategija diferenciacije « - povezanost med trditvami

74 Preglednica 32: Področje »Strategija diferenciacije « - KMO in Bartlettov test

74 Preglednica 33: Področje $\gg$ Strategija diferenciacije « - komunalitete

75 Preglednica 34: Področje »Strategija diferenciacije « - celotna pojasnjena varianca

75 Preglednica 35: Področje »Strategija diferenciacije « - matrika faktorskih uteži

76 Preglednica 36: Področje »Strategija nizkih stroškov in privlačnih cen «- povezanost med trditvami

77 Preglednica 37: Področje »Strategija nizkih stroškov in privlačnih cen « $-\mathrm{KMO}$ in Bartlettov test

77 Preglednica 38: Področje »Strategija nizkih stroškov in privlačnih cen «komunalitete

78 Preglednica 39: Področje »Strategija nizkih stroškov in privlačnih cen « - celotna pojasnjena varianca

78 Preglednica 40: Področje »Strategija nizkih stroškov in privlačnih cen « - matrika faktorskih uteži

79 Preglednica 41: Področje $\gg$ Strategija osredinjenja « - povezanost med trditvami

79 Preglednica 42: Področje »Strategija osredinjenja $\ll-\mathrm{KMO}$ in Bartlettov test

80 Preglednica 43: Področje $\gg$ Strategija osredinjenja $\ll-$ komunalitete

80 Preglednica 44: Področje »Strategija osredinjenja « - celotna pojasnjena varianca

8I Preglednica 45: Področje »Strategija osredinjenja « - matrika faktorskih uteži

8I Preglednica 46: Področje »Strategija prehitevanja $\ll-$ povezanost med trditvami

82 Preglednica 47: Področje $»$ Strategija prehitevanja $\ll-K M O$ in Bartlettov test

82 Preglednica 48: Področje »Strategija prehitevanja $\ll-$ komunalitete

83 Preglednica 49: Področje »Strategija prehitevanja « - celotna pojasnjena varianca

83 Preglednica 50: Področje »Strategija prehitevanja « - matrika faktorskih uteži 
87 Preglednica 51: Oznake spremenljivk v modelu SEM

88 Preglednica 52: Primerjava priporočenih in doseženih vrednosti modela SEM

89 Preglednica 53: Povzetek ugotovitev preverjanja hipoteze 



\section{Kratice}

AJPES Agencija Republike Slovenije za javnopravne evidence in storitve

BON Bonitetna ocena

CFI Mera relativnega prileganja (angl. Comparative Fit Index)

CPM Management procesov usmerjen v kupca (angl. Customer Process Management)

EU Evropska unija

EVA Ekonomska dodana vrednost (angl. Economic Value Added)

GVIN Javna spletna baza podatkov o poslovanju podjetij v Republiki Sloveniji

$\mathrm{H} \quad$ Hipoteza

KMO Kaiser-Meyer-Olkinova mera vzorčne ustreznosti

MSP Majhna in srednja podjetja

NFI Mera relativnega prileganja (angl. Normed Fit Index)

RMSEA Mera absolutnega prileganja (angl. Root Mean Square Error of Approximation)

ROA Donosnost sredstev (angl. Return on Assets)

ROE Donos na kapital (angl. Return on Equity) 
Strategije in uspešnost podjetja

SEM

SKD

SPSS

TLI
Modeliranje strukturnih enačb (angl. Structural Equation Modelling)

Standardna klasifikacija dejavnosti

Programska oprema za analiziranje družboslovnih podatkov (angl. Statistical Package for Social Sciences)

Nenormirani indeks prileganja (angl. Tucker-Lewis Index) 


\section{1 \\ Uvod}

Doseganje ciljev vsakega podjetja je proces. Ta proces zahteva skrbno planiranje in usmerjanje poslovanja podjetja $\mathrm{k}$ določenemu cilju, kar imenujemo strategija (Pučko 2003, 169-171; Kralj 2003, 95-135). Strategija je po N. Strecker $(2009,6 \mathrm{I})$ način, s katerim se podjetje odloči, da bo tekmovalo. Harmon $(2007,42)$ in drugi (Hauschildt 1991, 19; Altman 2003, 16; Friday in Friday 2003, 863; Strecker 2009, 4I; Alzahrani 2019, 73; Bellamy idr. 2019, 337; Wiengarten idr. 2019, 540; Davis 2020, 58; Liao, Fu in Zhiying 2020, 23; Signoretti 2020, 149; Shan-Huei idr. 2020, 76; Wurthmann 2020, 38) ugotavljajo, da je ravno strategija podjetja ključni element zagotavljanja konkurenčne prednosti in uspešnosti podjetja. Hernaus, M. Pejić Bach in V. Bosilj Vukšič (2012, 383; Wagner in Paton $2014,470)$ povezujejo strategije in notranje procese v podjetju ter uspešnost podjetja in izpostavljajo, da je pri načrtovanju poslovanja podjetja treba zajeti več različnih vidikov, ki vključujejo okolje podjetja, strateški pogled razvoja podjetja in tržno usmerjenost. Tupa (2010) celo pravi, da so lahko uspešna samo tista podjetja, ki svoje procese izvajajo skladno s spremembami v okolju, katerega del so kupci, in da lahko le tako razvijejo prednost pred konkurenti.

Monografija obravnava področje strateškega managementa s poudarkom na vplivu izbranih dejavnikov okolja (kupci, dobavitelji, konkurenti, tehnologija) na izbor strategije podjetja do kupcev (strategija diferenciacije, strategija nizkih stroškov in privlačnih cen, strategija osredinjanja, strategija prehitevanja) in na uspešnost poslovanja podjetja. Preučevanje vplivov okolja, strategij podjetja do kupcev in njihovega vpliva na uspešnost poslovanja podjetij je kompleksno, saj na uspešnost podjetja vpliva 
vrsta dejavnikov, ki jih vseh hkrati v eno raziskavo ne moremo zajeti, zato povezave med izbranimi dejavniki v tej raziskavi obravnavamo kot model.

\section{Izhodišča in opis ožjega znanstvenega področja raziskovanja}

Znanstveno področje $\mathrm{v}$ tej monografiji je področje managementa in organizacije, natančneje, strateškega managementa. Ožje področje preučevanja je raziskovanje vpliva zunanjega okolja podjetja, ki vključuje kupce, dobavitelje, konkurente in tehnologijo, na izbor strategije podjetja podjetja do kupcev ter na uspešnost podjetja. Zasnovali smo model povezav med izbranimi dejavniki, razvili hipotezo in v empiričnem delu preverili njeno veljavnost ter razvili predloge za večjo uspešnost podjetij.

\section{Opredelitev raziskovalnega problema}

Uspešnost podjetja je v literaturi obravnavana na različne načine. Bojnec idr. (2007, 219) uporabljajo pojem uspešnost poslovanja, Kralj (2003, 198) uporablja pojem poslovni uspeh podjetja, $\mathrm{v}$ svetovni literaturi pa se za uspešnost podjetja uporablja angleški izraz performance (Strecker 2009; Keong 2013; Banker, Mashruwala in Tripathy 2014; Delgado idr. 2014; Guo in Cao 2014; Keong 2014; Wagner in Paton 2014; Carey 2015; Peronja 2015; Bartz in Winkler 2016; Bisogno idr. 2016; Ensslin idr. 2017; Rezaei, Ortt in Trott 2018). Po Kralju (2003, 20I) je uspešnost lastnost podjetja navzven (gibčnost), ki jo merimo s tržnostjo kot konkurenčnostjo izdelkov in storitev ter s prožnostjo (sposobnostjo prilagajanja spremembam iz okolja in vplivanja na okolje). Tudi po Tupi (2010) so lahko uspešna samo tista podjetja, ki svoje procese izvajajo skladno s spremembami v okolju.

Trkman idr. (2015, 250) in drugi ugotavljajo, da je upoštevanje vidika kupcev ključni dejavnik uspešnosti podjetja (Margherita 2014, 642; Kabale in Kituyi 2015, 80; Heikkila idr. 2016, 337; Lau idr. 2016, 233), saj so izdelki in storitve namenjeni njim. N. Strecker $(2009,79)$ ugotavlja, da če smo osredotočeni na konkurenco, lažje zaznamo trende v panogi tudi na področju potreb kupcev in prav tako na področju tehnologije, kar je ceneje, kot če bi trg raziskovali sami. Raziskovalci (Crosby 1990; Vujoševič 1992; Zahra in Covin 1993; Champy 1995; Garvin 1998; Mulej idr. 2000; Kaplan in Norton 1996; 2000; Capra 2002; Markič 2003; Calantone, Garcia in Droege 2003; Danneels in Sethi 2003; Kirca, Jayachandran in Bearden 2005; Strecker 2009; Vom Brocke idr. 2014; Potočan in Nedelko 2015; Schwab 2016) ugotavljajo, da nova tehnologija pozitivno vpliva na uspešnost podjetja in da so podjetja, ki so usmerjena v rabo sodobne tehnologije, na trgu uspešnejša. Odgovornost vodstva podjetja je, 
da vzpostavi dobre odnose tudi s svojimi dobavitelji (Unterlechner, Meško Štok in Markič 2009, 74). Dobri odnosi z dobavitelji podjetju pomagajo do višje učinkovitosti proizvajanja ter do boljše prodaje (Aschhoff in Schmidt 2008, 4I; Rezaei, Ortt in Trott 2018, 644).

Pri izboru strategije podjetja do kupcev imajo podjetja več možnosti: strategijo diferenciacije, strategijo nizkih stroškov in privlačnih cen, strategijo osredinjenja, strategijo prehitevanja (Biloslavo 2006; Strecker 2009).

Strategija diferenciacije pomeni, da podjetje ponuja edinstven izdelek/storitev, ki učinkoviteje izpolnjuje zahteve kupca kot konkurenca (Porter 1980 v Biloslavo 2006, I80; Banker, Mashruwala in Tripathy 2014, 872). Podjetja, ki uporabljajo strategijo diferenciacije, ne smejo prezreti svoje cenovne pozicije na trgu (Strecker 2009, 63). Strategija nizkih stroškov in privlačnih cen daje poudarke na učinkovitost (produktivnost) notranjih procesov v podjetju, prav tako pa se osredotoča na celotno vrednostno verigo, dobavitelje, procese $\mathrm{v}$ podjetju in poprodajne procese (Vasquez, Santos in Alvarez 2001 v Strecker 2009, 62; Isomura in Pei-Yuh 2015, 7). Osredinjenje pomeni, da podjetje svoje zmožnosti osredinja na ožjo skupino kupcev, ožji trg, ožji nabor izdelkov/storitev. Nandakumar, A. Ghobadian in O'Regan (2009, 222; Koo, Koh in Nam 2004, I63) so ugotovili pozitiven vpliv uporabe strategije osredinjenja na uspešnost podjetja. Strategija prehitevanja pomeni, da podjetje $\mathrm{v}$ primerjavi $\mathrm{s}$ konkurenco porabi manj časa za uvajanje sprememb, razvoj izdelkov/storitev in njihovo uvajanje na trg (Biloslavo 2006, I8I). Ta strategija omogoča učinkovitejše servisiranje odjemalcev, izboljšanje obstoječih in snovanje novih procesov, prav tako v ospredje postavlja čas izvajanja procesov kot ključni dejavnik konkurenčnosti (odzivnost na spremembe v okolju, prehitevanje konkurentov) (GlavanMilanović 201 I, 25; Dumas idr. 2013; Sinur, Odell in Fingar 2013 v Potočan in Nedelko 2015, 23-24; Wagner in Paton 2014, 470).

D. Thennakoon idr. (2018, 478; Espino-Rodriguez in Rodriguez-Diaz 2014,2 ) izpostavljajo pomen povezav strategij s cilji podjetja in pri tem usmerjenost v koristi za kupca. Imeti moramo jasno postavljena merila za merjenje učinkov strategij na naše poslovanje (Hudson, Smart in Bourne 2001; Ljungberg 2002; Harmon 2003; Smith in Fingar 2003; Burlton 2010; Sinur, Odell in Fingar 2013; Janeš in Faganel 2013; Jeston in Nelis 20I4; Margherita 20I4; Trkman, Budler in Groznik 2015; Trkman idr. 2015; Lau idr. 2016; Rowell 2018; Arias idr. 2018).

V skladu s temi spoznanji se zastavljajo vprašanja: kateri so tisti dejavniki okolja, ki najbolj vplivajo na to, kakšno strategijo do kupcev bodo 
podjetja uporabila, katero strategijo uporabljajo najuspešnejša podjetja ter na kateri kazalnik uspešnosti podjetja vpliva uporaba posamezne strategije.

$\mathrm{Na}$ osnovi teh spoznanj izpostavljamo problemsko področje v tej raziskavi, ki je, kako okolje podjetja, ki vključuje kupce, konkurente, tehnologijo in dobavitelje, vpliva na izbor strategije podjetja podjetja do kupcev ter kako posledično uporaba posamezne strategije vpliva na uspešnost podjetja. To predstavlja naš osrednji raziskovalni problem.

Zasnovali smo model povezav med izbranimi dejavniki, razvili hipotezo in v empiričnem delu preverili veljavnost modela ter veljavnost zastavljene hipoteze.

\section{Namen in cilji raziskave}

Namen raziskave je sistematičen pregled domače in tuje strokovne literature $s$ področja vplivov sprememb v okolju na podjetje ter strategij podjetja do kupcev, zasnova modela povezav med izbranimi dejavniki okolja, strategijami in uspešnostjo podjetja ter izvedba empirične raziskave o vplivu strategij podjetja do kupcev na uspešnost podjetij (slika r).

Cilji raziskave so:

- Podrobna preučitev dostopne literature in obstoječih raziskav na področju vplivov okolja na podjetje in na izbor strategije podjetja do kupcev. Opravili smo obsežen pregled bibliografskih enot domače in tuje strokovne literature za zadnjih trideset let.

- Preverjanje izvirnega modela o vplivu okolja na izbor strategije podjetja do kupcev in na uspešnost podjetja (slika I).

- Izvedba empirične raziskave o tem, kakšne so povezave med izbranimi dejavniki: spremembe v okolju, strategije podjetja do kupcev in uspešnost podjetij.

Cilj raziskave je potrditi ali ovreči zastavljeno hipotezo in na osnovi spoznanj razviti predloge za večjo uspešnost podjetij. Podroben opis temeljne hipoteze in opis potrjevanja sledita v nadaljevanju.

\section{Predstavitev temeljne hipoteze raziskave}

$\mathrm{Na}$ uspešnost podjetja vpliva več dejavnikov. Zaradi velikega števila teh dejavnikov in izvedljivosti raziskave vseh naenkrat v raziskavo ne moremo zajeti. Zato smo vključili le izbrane dejavnike (spremembe okolja podjetja, strategija podjetja do kupcev), za katere smo predpostavili, da vplivajo na uspešnost podjetja. Dejavnike smo izbrali na podlagi preučitve literature in virov v teoretičnem delu raziskave (Crosby 1990; Vujoševič 1992; 
Zahra in Covin 1993; Champy 1995; Gatignon in Xuereb 1997; Garvin 1998; Mulej idr. 2000; Kaplan in Norton 2000; Capra 2002; Markič 2003; Calantone, Garcia in Droege 2003; Danneels in Sethi 2003; Kirca, Jayachandran in Bearden 2005; Strecker 2009; Keong 2013; Banker, Mashruwala in Tripathy 2014; Delgado idr. 2014; Guo in Cao 2014; Keong 2014; Wagner in Paton 2014; Carey 2015; Bartz in Winkler 2016; Bisogno idr. 2016; Ensslin idr. 2017; Rezaei, Ortt in Trott 2018).

Povezave med dejavniki okolja, strategijami podjetja do kupcev in uspešnostjo podjetja $\mathrm{v}$ tej raziskavi obravnavamo kot model (slika I). Podrobni opis modela in teh dejavnikov je opisan v poglavju $\gg$ Teoretični model povezav med dejavniki, hipoteza in merski instrument «. Na podlagi teoretičnih izhodišč ter skladno z namenom in cilji te raziskave smo oblikovali naslednjo temeljno hipotezo.

Hipoteza: Spremembe v okolju vplivajo na izbor strategije podjetja do kupcev, kar rezultira v uspešnosti podjetja. Podjetja, ki uporabljajo strategijo diferenciacije, so uspešnejša, kot tista, ki uporabljajo eno od ostalih strategij (strategijo nizkih stroškov in privlačnih cen, strategijo osredinjenja, strategijo prehitevanja).

V sklopu potrjevanja hipoteze smo v empiričnem delu raziskali: (I) ali obstajajo statistično značilne povezave med izbranimi dejavniki iz okolja (kupci, konkurenti, tehnologija, dobavitelji) in strategijami podjetja do kupcev; (2) kakšne so te povezave: šibke, močne; (3) ali naša temeljna hipoteza velja; (4) kateri posamezni dejavnik v sklopu hipoteze ima največji vpliv na uspešnost podjetja; (5) na katere kazalnike uspešnosti podjetja obstaja statistično značilen vpliv (ROA - poslovna donosnost sredstev, ROE - donosnost kapitala, EVA - ekonomska dodana vrednost, BON - bonitetna ocena); (6) kakšne so te povezave (šibke, močne); ter (7) kakšen je ta vpliv (pozitiven, negativen). Rezultate analize podrobneje predstavljamo v poglavju »Rezultati empirične raziskave«.

\section{Uporabljene metode raziskovanja}

Monografija je razdeljena na teoretični in empirični del. V teoretičnem delu zajema pregled tuje in domače znanstvene literature ter analizo in povzetek spoznanj, ki predstavljajo teoretično izhodišče za nadaljnjo raziskavo. $\mathrm{V}$ teoretičnem delu smo za opredelitev pojmov in pojavov, povezanih $s$ temo raziskovanja, uporabili metode: analize sekundarnih virov (člankov, knjig, znanstvene literature in virov), deskripcije (opisovanje posameznih pojmov, primerjave, razlike, citati drugih avtorjev, povzet$\mathrm{ki}$ in spoznanja drugih avtorjev), komparacije (primerjave dejstev in spoznanj) in sinteze spoznanj. 
Osrednji del raziskave je lastna empirična raziskava, ki vsebuje kvantitativni način zbiranja podatkov z anketnim vprašalnikom in statistično obdelavo zbranih podatkov. Raziskovanje vplivov na uspešnost podjetja v tej raziskavi (slika I) smo izvedli s pomočjo že uporabljenih merskih instrumentov (merjenje sprememb izbranih dejavnikov zunanjega okolja podjetja in merjenje strategij podjetja do kupcev).

V okviru statistične obdelave zbranih podatkov v empiričnem delu smo kot osrednjo metodo uporabili:

- modeliranje strukturnih enačb (angl. Structural Equation Modelling - SEM), saj smo preverili povezave in vplive med različnimi spremenljivkami (trditvami), preverili smo teoretični model (slika r).

V okviru strukturnih modelov smo uporabili:

- korelacijsko analizo, za preučevanje povezanosti med spremenljivkami (trditvami);

- multiplo regresijsko analizo, za preverjanje odvisnosti med spremenljivkami (trditvami);

- eksploratorno faktorsko analizo.

Potek izvedbe raziskave in rezultati so predstavljeni v poglavju $\gg$ Rezultati empirične raziskave«.

\section{Omejitve in predpostavke raziskovanja}

Za pravilno interpretacijo in razumevanje rezultatov raziskave je treba upoštevati omejitve in predpostavke raziskovanja. Omejitve v tej raziskavi lahko razdelimo na vsebinske in metodološke. Vsebinske omejitve izhajajo iz opredelitve ožjega področja raziskovanja, ki smo ga predstavili v predhodnem poglavju. Metodološke omejitve se nanašajo na metode raziskovanja, ki smo jih uporabili v empiričnem delu raziskave.

Na podlagi opredeljenega problema raziskovanja izpostavljamo naslednje vsebinske omejitve raziskave:

- Vsebinsko se omejujemo na preučevanje vplivov le izbranih dejavnikov okolja na izbor strategije podjetja do kupcevin na uspešnost v podjetja $\mathrm{Na}$ uspešnost podjetja vpliva več dejavnikov, ki jih vseh hkrati v eno raziskavo ne moremo zajeti, zato povezave med izbranimi dejavniki v tej raziskavi obravnavamo kot model (slika I). 
- Zaradi izvedljivosti raziskave (obsega in osredotočenosti) ter zaradi posploševanja rezultatov raziskave smo ocenili, da je smiselno, da se omejimo le na majhna in srednje velika podjetja (MSP). Ocenili smo, da bo uporabnost rezultatov raziskave za MSP največja.

- Omejili smo se na MSP v Republiki Sloveniji, ki so bila na dan II. I. $2017 \mathrm{v}$ javni bazi podatkov o poslovnih subjektih (AJPES) evidentirana kot delujoča podjetja. Za MSP smo se odločili, ker v Evropski uniji (EU) in tudi v Sloveniji predstavljajo največji segment podjetij. V Republiki Sloveniji MSP ustvarijo 25,4-odstotni delež vseh prihodkov glede na prihodke vseh podjetij (mikro, MSP, velika) in zaposlujejo skupaj več kot polovico (53,6 \%) vseh zaposlenih oseb (Statisični urad Republike Slovenije 2017).

- Za opredelitev MSP smo uporabili merila, ki so zapisana $v \gg Z a-$ konu o gospodarskih družbah « (2006). Merilo ustreznosti velikosti podjetja je bilo število zaposlenih (Io do 49 za majhno podjetje in 50 do 249 za srednje podjetje).

- V raziskavo smo glede na statusnopravno obliko vključili samostojne podjetnike (s. p.), družbe z omejeno odgovornostjo (d. o. o.), družbe z neomejeno odgovornostjo (d. n. o.) in delniške družbe (d. d.). Brez omejitve pravnega statusa bi baza podatkov o podjetjih zajela tudi razne javne agencije, sodišča, upravne enote ipd., ki niso bili ciljna populacija. Podjetij v stečaju, likvidaciji ali v prisilni poravnavi prav tako nismo vključili.

- Omejitev predstavlja okvir raziskave. Vsebinsko smo v modelu vplivov na uspešnost podjetja zajeli dejavnike (I) sprememb v zunanjem okolju podjetja, (2) strategije podjetja do kupcev. Uspešnost podjetij smo merili z izbranimi finančnimi kazalniki (ROA, ROE), operativnim kazalnikom (EVA) in s kazalnikom celovite uspešnosti podjetja (BON). Te kazalnike smo izbrali na podlagi preučene literature $\mathrm{v}$ teoretičnem delu raziskave.

Omejitev raziskave na MSP v Sloveniji utemeljujemo s sledečimi utemeljitvami: V EU 99 \% MSP deluje v zasebnem sektorju, so gonilo gospodarske rasti, inovacij, zaposlovanja in so steber evropskega gospodarstva. V njih se ustvarjata dve tretjini vseh delovnih mest $\mathrm{v}$ zasebnem sektorju in zagotavlja stopnjo rasti zaposlovanja. Ta je dvakrat večja kot v večjih podjetjih. MSP imajo pomembno vlogo pri ustanavljanju novih delovnih mest (Gouardères 2015). Tudi v Sloveniji velja podoben trend. MSP v Sloveniji zaposlujejo 53,6 \% vseh zaposlenih oseb (Statisični urad Republike Slovenije 2017). Trendi glede MSP v Sloveniji so pozitivni tako na 
področju zaposlovanja kot odpiranja novih podjetij in preživetja obstoječih (Slovenska tiskovna agencija 20I6). MSP niso miniaturna verzija velikih podjetij (Rezaei, Ortt in Trott 2015, 1527; Kumar in Kumar Singh 2017, 635; Rezaei, Ortt in Trott 2018, 631). Če hočejo obstati, morajo biti izjemno prožna, ko gre za spremembe v njihovem okolju. Njihove lastnosti lahko strnemo v naslednje: MSP imajo bistveno bolj omejene vire kot velika podjetja (Bretherton in Chaston 2005, 274) in morajo za doseganje konkurenčnosti posegati po zunanjih virih (Bojica, del Mar Fuentes-Fuentes in Fernández Pérez 2017, 205; Rezaei, Ortt in Trott 2018, 63I), ponavadi nimajo podrobno izdelanih strategij in se pogosto osredotočajo na posamezne vidike, ki jih je treba upoštevati pri strategijah v zvezi skupci in vrednostjo, ki jo razvijajo v notranjih procesih podjetja (Arbussa, Bikfalvi in Marques 2017, 271; Heikkila, Bouwman in Heikkila 2018, IIо).

MSP si po Fossu in T. Saebi $(2017,200)$ prizadevajo za naslednje tri strateške cilje: (I) razvoj novih področij poslovanja, (2) ohranjanje rasti in (3) povečanje dobičkonosnosti. MSP so ponavadi vpeta $\mathrm{v}$ oskrbno verigo večjih podjetij. Sodelovanje z večjimi podjetji lahko MSP omogoči večje osredinjenje na lastne temeljne zmožnosti in na razvoj novih (Rezaei, Ortt in Trott 2018, 630). S sodelovanjem z večjimi podjetji v oskrbni verigi lahko MSP lažje dostopajo do novih tehnologij, lažje razvijejo nove izdelke/storitve in s tem izboljšajo svojo inovativnost in konkurenčnost (Thakkar, Kanda in Desmukh 20I2, 634; Rezaei, Ortt in Trott 2018, 630). Ker imajo manj razpoložljivih človeških virov kot velika podjetja, se to odraža tudi v njihovi organiziranosti: MSP imajo manj podrobno delitev dela, manj hierarhične organizacijske strukture kot velika podjetja, hkrati pa so zato sposobna večje prilagodljivosti na spremembe v okolju in svojo konkurenčnost pogosto dosegajo $\mathrm{z}$ večjo inovativnostjo (Strecker 2009, 41; Guo in Cao 20I4, 273; Bartz in Winkler 2016, 196; Rezaei, Ortt in Trott 2018, 629).

$\mathrm{Na}$ podlagi postavljenih hipotez ter izbranih metod raziskovanja $\mathrm{v}$ raziskavi izpostavljamo naslednje metodološke omejitve:

- Omejitev raziskave predstavlja merski instrument. Uporabili smo kvantitativni način zbiranja podatkov s pomočjo spletnega anketnega vprašalnika zaprtega tipa. Podroben opis strukture vprašalnika je v poglavju »Rezultati empirične raziskave« in v prilogi I.

- Omejitev predstavlja populacija MSP v Sloveniji in vzorec 163 podjetij, od katerih smo pridobili ustrezno izpolnjene anketne 
vprašalnike. Več o vzorcu opisujemo v poglavju »Rezultati empirične raziskave «.

- Anketiranci so anketo izpolnjevali prostovoljno. Omejitev predstavlja pripravljenost anketirancev, da so nam prostovoljno zaupali ime podjetja, kar je bil v nadaljevanju pogoj za uspešno pridobivanje podatkov iz javno dostopnih baz o uspešnosti podjetij (ROA, ROE, EVA, BON).

- Anonimnost pri anketiranju smo zagotovili s tem, da imen anketirancev, imen podjetij in poslovnih skrivnosti nismo objavili. Podatke smo obdelali agregatno (skupaj v povprečnih vrednostih) in $\mathrm{v}$ interpretaciji niso povezani $s$ posameznim podjetjem ali anketirancem.

Pojasnila $\mathrm{v}$ povezavi z omejitvami, obsegom, namenom in anonimnostjo raziskave smo ob pošiljanju prošnje podjetjem za sodelovanje vključili v uvodni nagovor in spremni dopis.

Izpostavljamo tudi predpostavke, ki smo jih definirali pred raziskovanjem. Pojasnilo predpostavk je potrebno za nadaljnje razumevanje vsebine ter interpretacije rezultatov.

- Na podlagi analize sistematičnega pregleda tuje in domače literature smo ugotovili vrzel, saj še ni bila narejena raziskava o vplivih okolja na izbor strategije podjetja do kupcev in na uspešnost podjetij.

- Obvladovanje odzivov na spremembe v okolju in zasnova primernih strategij podjetja do kupcev predstavljata za podjetja izziv in obstaja interes managerjev, da se stanje na tem področju v podjetjih izboljša.

- Predpostavljamo, da je kvantitativni način zbiranja podatkov za to raziskavo najprimernejši.

- Predpostavljamo, da so vrhnji managerji v podjetjih najprimernejši za vključitev v raziskavo. Anketne vprašalnike smo naslovili na direktorje s prošnjo, da jih izpolnijo oni sami ali njihovi kompetentni sodelavci.

- Predpostavljamo, da so anketiranci objektivno in vestno odgovarjali na vprašanja $v$ anketi ter da so njihovi odgovori odraz dejanskega stanja v podjetju, za katero so anketo izpolnili.

- Predpostavljamo, da obstaja vpliv le med izbranimi dejavniki okolja, strategijami podjetja do kupcev in uspešnostjo podjetja (slika I). 



\section{Okolje, strategije in uspešnost podjetja}

Uvodoma opredeljujemo uspešnost podjetja, saj nam v nadaljevanju raziskave, predstavljenem $\mathrm{v}$ poglavju $\gg$ Teoretični model povezav med dejavniki, hipoteza in merski instrument «, pomaga razumeti povezanost s posameznimi dejavniki, ki smo jih zajeli v naš model (slika I). Opredeljujemo izbrane dejavnike: (I) dejavnik »Spremembe v okolju « podjetja, ki zajema področja: $\gg$ Kupci«, $\gg$ Konkurenti «, $\gg$ Tehnologija $\ll$ in $\gg$ Dobavitelji«, (2) dejavnik »Strategije podjetja do kupcev«, ki zajema področja: »Strategija diferenciacije «, »Strategija nizki stroški in privlačne cene «, 》Strategija osredinjenja «, »Strategija prehitevanja «. Izhajamo iz teoretičnega ozadja, ki smo ga predstavili v uvodnih poglavjih. $\mathrm{Na}$ koncu tega poglavja povzemamo ugotovitve kot podlago za nadgradnjo vsebine $\mathrm{v}$ empiričnem delu raziskave, predstavljenem $\mathrm{v}$ poglavju $\gg$ Rezultati empirične raziskave«.

\section{Opredelitev uspešnosti podjetja}

$\mathrm{Na}$ vprašanje, kaj je uspešnost, ni preprosto odgovoriti. Uspešnost pomeni »uspešno delovati, se uveljaviti; je lastnost, značilnost in pomeni, da s svojim delom, prizadevanjem dosegamo take rezultate, kot želimo, pričakujemo (podjetje dobro uspeva, gospodarsko uspevati) « (Slovar slovenskega knjižnega jezika 20I8). Uspešnost podjetja je v literaturi obravnavana na različne načine. Bojnec idr. (2007, 219) uporabljajo pojem uspešnost poslovanja, Kralj (2003, 198) uporablja pojem poslovni uspeh podjetja, v svetovni literaturi pa se za uspešnost podjetja uporablja angleški izraz performance (Goldsmith in Clutterbuck 1984; Dollinger in Golden 1992; 
Dawes 1999; Kotabe, Srini in Aulakh 2002; Brouthers, Brouthers in Werner 2003; Buck idr. 2003; Capar in Kotabe, 2003; Doukas in Lang 2003; Tangen 2005; Miers 2006; Reuer in Tong 2007; De Wall 2008; Hult idr. 2008; Strecker 2009; Keong 2013; Banker, Mashruwala in Tripathy 2014; Delgado idr. 2014; Guo in Cao 2014; Keong 2014; Wagner in Paton 2014; Carey 2015; Peronja 2015; Bartz in Winkler 2016; Bisogno idr. 2016; Ensslin idr. 2017; Rezaei, Ortt in Trott 2018). Po Kralju (2003, 201) je uspešnost lastnost podjetja navzven (gibčnost), ki jo merimo s tržnostjo kot konkurenčnostjo izdelkov in storitev ter s prožnostjo (sposobnostjo prilagajanja spremembam iz okolja in vplivanja na okolje). Kralj (2003, 20I) uspešnost podjetja povezuje z učinkovitostjo (produktivnostjo virov oz. sredstev, ekonomičnostjo rabe sredstev). Nandakumar, A. Ghobadian in O'Regan $(2009,250)$ in Hambrick $(1983,687)$ uspešnost podjetja opredeljujejo kot stopnjo doseganja ciljev (dobiček) in kot relativni uspeh glede na konkurenco. Allen in M. M. Helms $(2006,438)$ in drugi (Goldsmith in Clutterbuck 1984; Strecker 2009; Delgado idr. 20I4) pravijo, da se uspešnost podjetja kaže v finančnem rezultatu (dobiček). Uspešnost lahko enačimo z inovativnostjo podjetja, saj je dobiček podjetja posledica inovativnosti (Strecker 2009, 4I). Hult idr. (2008, ı 69-ı070) uspešnost podjetja razumejo kot ugled ter sposobnost prilagajanja na spremembe v okolju in predlagajo, da pri merjenju uspešnosti podjetja zajamemo več različnih kazalnikov: finančne, operativne in celovite. Pri tem predlaga, da zajamemo tudi eno- do triletna obdobja in da za objektivnejšo oceno uspešnosti upoštevamo povprečne vrednosti posameznih kazalnikov (Hult idr. 2008, I073).

Če povzamemo, lahko uspešnost podjetja razumemo in definiramo na različne načine. $\mathrm{V}$ tej raziskavi poenoteno uporabljamo izraz uspešnost podjetja. Za pravilno interpretacijo uspešnosti podjetja je treba hkrati gledati več različnih kazalnikov te uspešnosti (Bojnec idr. 2007, 219). Posamezni kazalnik nam namreč lahko poda izkrivljeno sliko o tem fenomenu. Za potrebe naše raziskave v empiričnem delu raziskave uspešnost podjetja merimo s pomočjo različnih kazalnikov: finančnih (ROA, $\mathrm{ROE}$ ), operativnega (EVA) in celovitega (BON), kot predlagajo Hult idr. (2008, I069). Več različnih kazalnikov smo uporabili zato, ker posamezni kazalnik lahko poda izkrivljeno sliko o uspešnosti podjetja. $\mathrm{Ob}$ tem smo upoštevali tudi omejitev dostopnosti javnih podatkov o poslovanju podjetij. Podroben opis o uporabljenih kazalnikih uspešnosti podjetja v našem modelu raziskav se nahaja $v$ poglavju $\gg$ Rezultati empirične raziskave $\ll$. 
Za doseganje ciljev raziskave $\mathrm{v}$ nadaljevanju opisujemo vplive posameznih dejavnikov na uspešnost podjetja. Predstavljamo dejavnik (I) »Spremembe v okolju « podjetja in (2) dejavnik »Strategije podjetja do kupcev«. Vsebina $\mathrm{v}$ nadaljevanju je podlaga za razumevanje zastavljene hipoteze in interpretacijo rezultatov $\mathrm{v}$ empiričnem delu raziskave.

\section{Zunanje okolje in uspešnost podjetja}

$\mathrm{V}$ nadaljevanju najprej za vsakega izmed področij znotraj dejavnika »Spremembe v okolju«, kamor prištevamo kupce, konkurente, tehnologijo in dobavitelje, podajamo opis.

\section{Kupci}

Izdelki in storitve so izložki podjetij in so namenjeni kupcem. $S$ tega vidika se postavlja vprašanje, kako naj bodo v poslovanje podjetja vključeni kupci (Heikkila idr. 2016, 337). Trkman idr. (2015, 250) in drugi (Margherita 2014, 642; Kabale in Kituyi 2015, 80; Lau idr. 2016, 233; Stonehouse in Pemberton 2005, 250; Stonehouse, Pemberton in Barber 2001, II5; Stonehouse in Snowdon 2007, 256; Lau idr. 2016, 231) ugotavljajo, da je upoštevanje vidika kupcev ključni dejavnik uspešnosti podjetja. Poudarjajo tudi, da mora imeti podjetje, če želi biti konkurenčno, posebna znanja o procesih, ki so vezana na kupce. Markič (2003, 163) izpostavlja, da je treba za odlično kakovost izdelkov in storitev upoštevati zahteve kupcev. Appelbaum idr. (2015, 136-139) in Kondaskar (2014) manjšo uspešnost podjetij povezujejo s slabim sodelovanjem z udeleženci, pri čemer posebej izpostavljajo, da je za neuspešenost poslovanja podjetja krivo pomanjkanje orientiranosti v kupce. Kupce tudi Tavčar $(2009,196)$ ter Trkman idr. (2015, 250-266) povezujejo s sprotnim in prihodnjim doseganjem ciljev podjetja, ki ustrezajo interesom ne samo lastnikov, temveč tudi interesom drugih udeležencev. Iz tega lahko sklenemo, da je odzivanje na spremembe v okolju na področju kupcev smiselno vključiti v model vplivov na uspešnost podjetja (slika I).

\section{Konkurenti}

Biti konkurenčen pomeni, da kupcem služimo bolje kot naši konkurenti (Stecker 2009, 79). Uspešna podjetja se zato do neke mere morajo prilagajati svojim konkurentom v panogi. To ima nekatere prednosti in tudi slabosti. Prevelika osredotočenost na konkurente na drugi strani za podjetje lahko pomeni, da se bo sčasoma preveč poudarka dalo stroškom. Prav tako N. Strecker (2009) in drugi predvidevajo, da se podjetja na konku- 
renco v enaki panogi odzivajo podobno (Gatignon in Xuereb 1997, 80; Strecker 2009,79$)$. To se odraža tudi na področju strategij v podjetju. Za razvoj konkurenčne prednosti podjetja na trgu Lau idr. (20I6, 23I) ugotavljajo, da moramo ne le z izdelki, ampak predvsem svojimi notranjimi procesi tekmovati s konkurenco (Stonehouse in Pemberton 2005, 250; Stonehouse, Pemberton in Barber 200I, II5; Stonehouse in Snowdon 2007, 256 v Lau idr. 2016, 231). Le z osredotočanjem na konkurenčnejše procese $\mathrm{v}$ primerjavi $\mathrm{z}$ našimi obstoječimi procesi in $s$ konkurenco bo podjetje lahko trajno obdržalo prednost v stroških, času, produktivnosti, izdelkih/storitvah (Benner in Tushman 2003, $238 \mathrm{v}$ Lau idr. 2016, 231). To je lahko podlaga za razvoj primernih strategij podjetja do kupcev. N. Strecker $(2009,79)$ pravi, da če smo osredotočeni na konkurenco, lažje zaznamo trende $\mathrm{v}$ panogi tudi na področju potreb kupcev in prav tako na področju tehnologije, kar je ceneje, kot če bi trg raziskovali sami. Zato v nadaljevanju predstavljamo tudi vpliv tehnologije kot dejavnika zunanjega okolja, ki vpliva na uspešnost podjetij.

\section{Tebnologija}

$\mathrm{Ob}$ preučevanju teoretičnih izhodišč, vezanih na vplive tehnologije na uspešnost podjetij, sledimo ugotovitvam različnih avtorjev (Crosby I990; Vujoševič 1992; Zahra in Covin 1993; Champy 1995; Garvin 1998; Mulej idr. 2000; Kaplan in Norton 2000; Capra 2002; Markič 2003; Calantone, Garcia in Droege 2003; Danneels in Sethi 2003; Kirca, Jayachandran in Bearden 2005; Strecker 2009; Vom Brocke idr. 2014; Potočan in Nedelko 2015; Schwab 2016). Capra (2002 v Unterlechner, Meško Štok in Markič 2009, I I 4) pravi, da nove tehnologije, globalizacija gospodarstva in nove oblike struktur organiziranosti lahko podpirajo konkurenčnost procesov in s tem konkurenčnost podjetij. Mulej idr. (2000; Markič 2003 v Unterlechner, Meško Štok in Markič 2009, I I 4) pravijo, da večina razlogov za stanje $\mathrm{v}$ podjetjih izhaja tudi iz neustreznega povezovanja novih tehnologij ter zamujanja pri njihovi integraciji v procese podjetja. Zahra in Covin (1993 v Strecker 2009, 43) ugotavljata, da nova tehnologija pozitivno vpliva na uspešnost podjetja in da so podjetja, ki so usmerjena v rabo sodobne tehnologije, na trgu uspešnejša. K novi (pravimo tudi sodobni) tehnologiji štejemo uporabo interneta, informacijsko-komunikacijske tehnologije, robotizacijo, digitalizacijo, virtualizacijo, internet stvari (angl. Internet of Things - IoT), nevrotehnologijo in njihove povezave (Bavec in Manzin 2012, I 18; Schwab 2016, 133-182). Po N. Strecker $(2009,64)$ so tehnološke spremembe eden izmed glavnih iniciatorjev sprememb v današnjem poslovnem okolju. Imenuje jih tehnološke 
turbulence (Calantone, Garcia in Droege 2003; Danneels in Sethi 2003; Kirca, Jayachandran in Bearden 2005 v Strecker 2009, 64). Po Potoča$\mathrm{nu}$ in Nedelku $(2015,29-30)$ sta za obvladovanje sprememb v dinamičnem okolju v podjetjih potrebni sodobna tehnologija in celovita informacijska podpora. Prav tako Bavec in Manzin (2012, I00) ugotavljata, da je sodobna računalniška tehnologija priložnost za izboljšave procesov. Vom Brocke idr. (2014, 530) ugotavljajo, da je sodobna informacijska tehnologija danes pogoj za uspešno uvajanje sprememb v podjetja. Dostop do novih tehnoloških rešitev nam lahko omogočijo tudi dobavitelji, ki so ponavadi specializirani za ožje področje poslovanja kot mi (Bavec in Manzin 2012, 106-109).

\section{Dobavitelji}

Vsako podjetje mora biti usmerjeno v izdelovanje izdelkov/izvajanje storitev za koristi kupcev. To podjetja dosegajo tudi s sodelovanjem in vključevanjem dobaviteljev v svoje procese. Odgovornost vodstva podjetja je, da vzpostavi takšne procese, pri katerih vladajo odlični odnosi med zaposlenimi, dobavitelji/izvajalci in kupci (Unterlechner, Meško Štok in Markič 2009, 74). Bavec in Manzin pojasnjujeta (2012, 106), da so zunanji izvajalci podjetja, ki na podlagi vnaprejšnjega dogovora dobavljajo blago/storitev, ki smo jo prej naročali znotraj podjetja (iz drugih oddelkov). Zunanje dobavitelje pa opredeljujeta kot tista podjetja, ki imajo lasten razvoj, ki delajo po lastnih standardih in se jim moramo do določene mere kot kupec prilagajati mi (str. I09). Ker je ta meja med zunanjimi izvajalci in zunanjimi dobavitelji pogosto zabrisana, bomo v naši raziskavi uporabljali poenoten izraz zunanji dobavitelji (oz. dobavitelji). Koristi, ki jih ima podjetje pri sodelovanju z dobavitelji, so povezane s tem, da se lahko osredotočimo na našo osrednjo sposobnost (I). Osrednjo sposobnost podjetja lahko opredelimo kot edinstveno kombinacijo poslovne specializiranosti in človeških veščin (str. 106-104). Osrednja (temeljna oz. ključna) sposobnost (zmožnost) je tista dejavnost podjetja, ki ima za kupce posebno tržno vrednost, je težko posnemljiva in jo lahko uporabimo v širokem naboru naših izdelkov/storitev (Prahalad in Hamel 1990 v Bavec in Manzin 2012, I06-I09). S tem je povezana usmeritev, da management poljubnega podjetja osrednjo sposobnost ohrani kot lastno dejavnost $\mathrm{v}$ lastnih procesih znotraj podjetja. (2) Dobavitelji nam lahko omogočijo hitrejši dostop do nove tehnologije, saj so ponavadi specializirani za ožje področje poslovanja. (3) Dobavitelji nam zaradi svoje specializacije lahko omogočijo nižje stroške, smotrnejšo rabo sredstev (finančna sredstva investiramo $v$ našo osrednjo sposobnost) in $s$ tem optimizacijo poslovanja. Le z njihovo 
pomočjo lahko podjetje optimira svoje poslovanje, kot npr. zaloge, logistiko, natančnost dobav ipd. (Angulo, Nachtmann in Waller 2004, IоI). Arend in Wisner (2005, 403) ter ostali avtorji (Arend 2006, 74I; Rezaei, Ortt in Trott 2018, 644) ugotavljajo, da slabi odnosi z dobavitelji negativno vplivajo na uspešnost podjetja. Prav tako lahko dobri odnosi z dobavitelji podjetju pomagajo do višje učinkovitosti proizvajanja ter do boljše prodaje (Aschhoff in Schmidt 2008, 4I; Rezaei, Ortt in Trott 2018, 644). (4) Od dobaviteljev lahko zaradi njihove specializacije pridobimo nova znanja, ki jih sami nimamo (Jiang, Frazier in Prater 2006, I 280), ter (5) dobavitelji nam lahko omogočijo prevlado nad konkurenco (vzdržujemo lahko nižje stroške in posledično nižje cene, omogočajo nam diferenciacijo, lahko so vir novih idej). Na primer: strategija nizkih stroškov in privlačnih cen daje poudarke na učinkovitost (produktivnost) notranjih procesov v podjetju, prav tako pa se osredotoča na celotno vrednostno verigo, torej na naše dobavitelje (Vasquez, Santos in Alvarez 200 I v Strecker 2009, 62). Za podjetja je pomembno, da odločitev o sodelovanju $\mathrm{z}$ dobavitelji pretehtajo $\mathrm{z}$ vidika stroškov in koristi. Management podjetja pa naj upošteva tudi koristi za izbranega dobavitelja tako, da bo sodelovanje spodbujalo dolgoročno uspešnost (Kavčič 2009, I3). Usmerjenost v rezultate poslovanja na podlagi korektnega sodelovanja z dobavitelji podpira tudi evropski model odličnosti poslovanja (EFQM 1999, 7), ki pravi, da je uspešnost podjetja odvisna od uravnoteženja in zadovoljevanja potreb vseh udeleženih strani (zaposleni, odjemalci, dobavitelji, družba na splošno, pa tudi tisti, ki imajo v podjetju finančne interese). Prav tako pomen dobaviteljev za uspešnost poslovanja podjetij vključuje standard ISO, ki poleg osredotočanja na kupce, procesni pristop, nenehne izboljšave posebej izpostavlja obojestransko koristne odnose z dobavitelji (ISO 9000:2000). V procesih podjetja je vedno prostor za inovativnost, izboljšave, kar lahko dosežemo tudi z vključevanjem dobaviteljev, saj tudi tako lahko razvijemo novo vrednost in korist za naše kupce.

Dejavnike sprememb okolja podjetja, ki smo jih opisali v prejšnjem poglavju, povezujemo s strategijo podjetja do kupcev. Zato v nadaljevanju podajamo opis pomena strategije podjetja do kupcev in povezanost $z$ uspešnostjo podjetja. Izhajamo iz podobnih raziskav na tem področju in predstavljamo ugotovitve ter podajamo sklepe.

$\mathrm{V}$ nadaljevanju za vsakega izmed področij znotraj dejavnika »Strategija podjetja do kupcev« nizkih stroškov in privlačnih cen «, »Strategija osredinjenja «, »Strategija prehitevanja $\ll$ - podajamo opis. 


\section{Strategija podjetja do kupcev in uspešnost podjetja}

Doseganje ciljev podjetja je proces. Ta proces zahteva skrbno planiranje in usmerjanje poslovanja podjetja $\mathrm{k}$ določenemu cilju, kar imenujemo strategija (Pučko 2003, I69-I7 I; Kralj 2003, 95-135). Strategija je po N. Strecker (2009, 6I) način, s katerim se podjetje odloči, da bo tekmovalo. Tavčar jo opredeljuje kot zaporedje aktivnosti za doseganje določenega cilja in pravi, da strategija zahteva opredelitev osnovnih ciljev podjetja $\mathrm{v}$ smeri akcije in tudi opredelitev virov, ki so potrebni za dosego ciljev (Tavčar 2009, 126, 199). Harmon (2007, 42) in drugi (Hauschildt 1991, 19; Altman 2003, I6; Friday in Friday 2003, 863; Strecker 2009, 4I) ugotavljajo, da je strategija podjetja ključni element zagotavljanja konkurenčne prednosti in uspešnosti podjetja. Hernaus, C. Pejić Bach in V. Bosilj Vukšič (2012, 383; Wagner in Paton 20I 4, 470) povezujejo strategije in procese ter uspešnost podjetja in izpostavljajo, da je $\mathrm{v}$ management procesov $\mathrm{v}$ podjetju treba zajeti več različnih vidikov, ki vključujejo strateški pogled razvoja podjetja in tržno usmerjenost. Tupa (2010) celo pravi, da so lahko uspešna samo tista podjetja, ki svoje procese izvajajo skladno s spremembami v okolju, katerega del so kupci, in da le tako lahko razvijejo prednost pred konkurenti. Spremembe procesov naj bi izhajale iz strategije podjetja (Laudien in Daxböck 2017, 420; Heikkila, Bouwman in Heikkila 2018, ı०8), zato v nadaljevanju dajemo opis temeljnih strategij podjetja do kupcev, ki so v našem modelu odvisna spremenljivka, za katero smo predpostavili, da vpliva na uspešnost podjetja (slika i).

\section{Strategija diferenciacije}

Strategija diferenciacije pomeni, da podjetje ponuja edinstven izdelek/ storitev, ki učinkoviteje izpolnjuje zahteve kupca kot konkurenca (Porter I980 v Biloslavo 2006, I80; Banker, Mashruwala in Tripathy 2014, 872). Od podjetja zahteva, da ponudi drugačen, spremenjen izdelek, od kupcev pa, da bodo za to dodatno plačali (Strecker 2009, 62). N. Strecker (2009, 2 I2) prav tako ugotavlja, da so podjetja, ki uporabljajo strategijo diferenciacije, inovativnejša in uspešnejša kot tista, ki te strategije ne uporabljajo. Nandakumar, A. Ghobadian in O'Regan $(2009,222)$ ter drugi (Kim in Mauborgne 2005; Koo, Koh in Nam 2004, I63) prav tako ugotavljajo, da so podjetja, ki uporabljajo strategijo diferenciacije, uspešnejša kot druga. Niehaves idr. (2014, 90) diferencirane izdelke povezuje z diferenciranimi in inovativnimi procesi, saj so izdelki izložki iz procesov. Podjetja, ki uporabljajo strategijo diferenciacije, ne smejo prezreti svoje cenovne pozicije na trgu (Strecker 2009, 63), zato podjetja to strategijo pogosto 
kombinirajo s strategijo nizkih stroškov in privlačnih cen, kar opisujemo v nadaljevanju.

\section{Strategija nizkih stroškov in privlačnih cen}

Berends idr. (2016, I8I) izpostavljajo, da je lahko osredotočanje na kupca in hkrati nizke stroške poslovanja leden izmed osnovnih poudarkov pri razvoju strategije podjetja. Strategija nizkih stroškov in privlačnih cen daje poudark učinkovitosti (produktivnosti) notranjih procesov v podjetju, prav tako pa se osredotoča na celotno vrednostno verigo, dobavitelje, procese v podjetju in poprodajne procese (Vasquez, Santos in Alvarez 2001 v Strecker 2009, 62; Isomura in Pei-Yuh 2015, 7). Ta strategija ščiti podjetja pred pritiski iz okolja in zahteva velike napore ter prinaša tveganja ob večjih tehnoloških spremembah na trgu (Porter 1980 v Biloslavo 2006, 180). Isomura in Pei-Yuh $(2015,39)$ predlagata, da podjetja za večjo uspešnost uvedejo strategijo vodje na področju nizkih stroškov in privlačnih cen ter tako v panogi ustvarijo vstopne ovire za potencialne nove tekmece. Prav tako predlagata, naj se podjetja ob nizkih stroških poslovanja osredotočijo na kupčeve potrebe in naj kupcu hkrati ponudijo novo vrednost ter upoštevajo kupčeve vrednote. G. L. Ge in Ding (2005, I I5) ugotavljata, da so podjetja, ki uporabljajo strategijo nizkih stroškov in privlačnih cen, sposobna še povečati tržni delež in dobiček, sploh če hkrati uporabljajo strategijo diferenciacije, kar potrjuje tudi N. Strecker (2009, 62). Tudi Kim, Nam in Stimpert (2004, 19) ter Parnell (2006, 230) za večjo uspešnost podjetja predlagajo kombinacijo strategije nizkih stroškov in privlačnih cen ter strategije diferenciacije. Po N. Strecker (2009, 2I 2) so podjetja, ki uporabljajo strategijo diferenciacije, inovativnejša in uspešnejša kot tista, ki te strategije ne uporabljajo. Nandakumar, A. Ghobadian in O'Regan $(2009,222)$ ugotavljajo, da so podjetja, ki uporabljajo strategijo nizkih stroškov in privlačnih cen v kombinaciji s strategijo diferenciacije, finančno uspešnejša. Ena izmed strategij, ki podjetju omogoča kombinacije z drugimi naštetimi strategijami, je tudi strategija osredinjenja, ki jo opisujemo v nadaljevanju.

\section{Strategija osredinjenja}

Osredinjenje pomeni, da podjetje svoje zmožnosti osredinja na ožjo skupino kupcev, ožji trg, ožji nabor izdelkov/storitev. Osredinjenje podjetju omogoča boljšo donosnost virov, osredotočanje na optimiranje obsega poslovanja in izvajanja dejavnosti ter posledično optimiranje procesov. To povezujemo tudi z namensko tehnologijo in drugimi rešitvami, ki so 
prilagojene našemu osredinjenju, ter z višjimi stroški poslovanja (investicija v namensko opremo je višja, vračilo vloženih sredstev pa počasnejše, kot če bi uporabili univerzalne rešitve). Uspešnost strategije osredinjanja je tako pogojena s tem, da so želje naših kupcev dovolj diferencirane in da so kupci za naše izdelke/storitve pripravljeni plačati višjo ceno (Porter I980 v Biloslavo 2006, I80). Podjetja to strategijo pogosto uporabijo takrat, ko ne uporabljajo strategije nizkih stroškov in privlačnih cen (Strecker 2009, 63). Nandakumar, A. Ghobadian in O'Regan (2009, 222; Koo, Koh in Nam 2004, 163) so ugotovili pozitiven vpliv uporabe strategije osredinjenja na uspešnost podjetja. Strategija osredinjenja zaradi osredotočanja na ožji nabor izdelkov/storitev na drugi strani pomeni tudi osredotočanje na manjše število procesov in s tem manjšo zahtevnost obvladovanja procesov v podjetju. Strategijo osredinjenja in druge strategije lahko podjetje vedno kombinira še s strategijo prehitevanja, ki je po Biloslavu (2006, I8I) celo najpomembnejša.

\section{Strategija prehitevanja}

Strategija prehitevanja pomeni, da podjetje v primerjavi s konkurenco porabi manj časa za uvajanje sprememb, razvoj izdelkov/storitev in njihovo uvajanje na trg. Pogosto se uporablja v kombinaciji z drugimi zgoraj navedenimi strategijami (Biloslavo 2006, I8I). S procesnega vidika delovanja podjetja ta strategija omogoča učinkovitejše servisiranje odjemalcev, izboljšanje obstoječih in snovanje novih procesov, prav tako v ospredje postavlja čas izvajanja procesov kot ključni dejavnik konkurenčnosti (odzivnost na spremembe v okolju, prehitevanje konkurentov) (GlavanMilanović 201 I, 25; Dumas idr. 2013; Sinur, Odell in Fingar 2013 v Potočan in Nedelko 2015, 23-24; Wagner in Paton 2014, 470).

Če povzamemo, naj strategija podjetja do kupcev izhaja iz splošne strategije podjetja. Podjetje bo manj uspešno, če v management procesov ne bo vključilo vidik kupca. Katero koli strategijo ali njihovo kombinacijo podjetje izbere, je za uspešno uporabo strategije potrebno, da management podjetja $\mathrm{v}$ udejanjanje strategije vključi vse nivoje zaposlenih (Appelbaum idr. 2015, 136-139). V empiričnem delu raziskave te strategije povezujemo z uspešnostjo podjetij. $S$ pomočjo spoznanj na področju vpliva zunanjih dejavnikov na uspešnost podjetja smo v nadaljevanju razvili hipotezo I (poglavje »Teoretični model povezav med dejavniki, hipoteza in merski instrument«). Izhajamo iz podobnih raziskav na tem področju in predstavljamo ugotovitve ter podajamo sklepe.

$\mathrm{Na}$ podlagi teoretičnih izhodišč, identificirane raziskovalne vrzeli ter skladno z namenom in cilji naloge smo oblikovali model povezav 
(slika I) ter razvili hipotezo. Podali smo teoretična ozadja in opis dejavnikov, za katere smo $\mathrm{v}$ našem modelu predpostavili, da imajo vpliv na uspešnost podjetja. Opisali smo: (I) dejavnik »Spremembe v okolju«, ka-

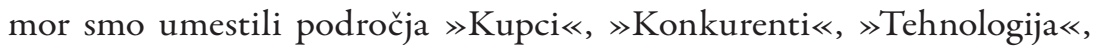
$\gg$ Dobavitelji«; (2) dejavnik »Strategija podjetja do kupcev« , kamor smo umestili področja $\gg$ Strategija diferenciacije «, »Strategija nizkih stroškov in privlačnih cen $\ll$, , Strategija osredinjenja $\ll$ ter $\gg$ Strategija prehitevanja $\ll$ (priloga I, priloga 2). 


\section{Teoretični model povezav, hipoteza in merski instrument}

V nadaljevanju tega poglavja predstavljamo zastavljen model raziskave, temeljni hipotezmerski instrument. Opisujemo dejavnike, za katere smo na osnovi teoretičnega dela te raziskave predpostavili, da imajo vpliv na uspešnost podjetja. V modelu smo zajeli dejavnik »Spremembe v okolju« in dejavnik »Strategije podjetja do kupcev«. Preučevanje vplivov teh dejavnikov na uspešnost poslovanja podjetij je kompleksno, saj na uspešnost podjetja vpliva vrsta dejavnikov, ki jih vseh hkrati v eno raziskavo ne moremo zajeti, zato povezave med izbranimi dejavniki v tej raziskavi obravnavamo kot model (slika I).

\section{Predstavitev modela raziskave}

Uvodoma predstavljamo model naše raziskave, ki za lažje razumevanje grafično prikazuje medsebojne vplive izbranih dejavnikov na uspešnost podjetja.

Model je poenostavitev realnega stanja ter je učinkovito sredstvo za izboljšanje učinkovitosti in uspešnosti poslovanja (Tavčar 2009, 62). Model je »način za ponazoritev, prikaz načrtovanega ali obstoječega « (Slovar slovenskega knjižnega jezika 2018). V praksi stremimo $\mathrm{k}$ temu, da so modeli preprosti in razumljivi ter pregledni, dovolj vsebinsko bogati in da jih je mogoče uporabiti čim obsežneje.

$\mathrm{Z}$ modelom $\mathrm{v}$ tej raziskavi pojmujemo povezave med izbranimi dejavniki. V modelu smo zajeli dejavnik $\gg$ Spremembe v okolju« in dejavnik »Strategije podjetja do kupcev«, za katera smo na podlagi raziskave literature $\mathrm{v}$ teoretičnem delu raziskave predpostavili, da imata vpliv 
na uspešnost podjetja. Stremeli smo k temu, da razvijemo model, ki bo vseobsežen in dovolj vsebinsko bogat ter hkrati preprost, razumljiv in pregleden.

V sklopu dejavnika »Spremembe v okolju« smo zajeli področja:

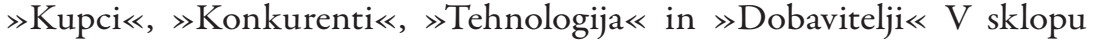
dejavnika »Strategija podjetja do kupcev« smo zajeli področja: »Strategija diferenciacije «, »Strategija nizkih stroškov in privlačnih cen $\ll$, $\gg$ Strategija osredinjenja «er $\gg$ Strategija prehitevanja $\ll$. Podroben opis merskega instrumenta za vsako izmed področij je opisan v nadaljevanju tega poglavja.

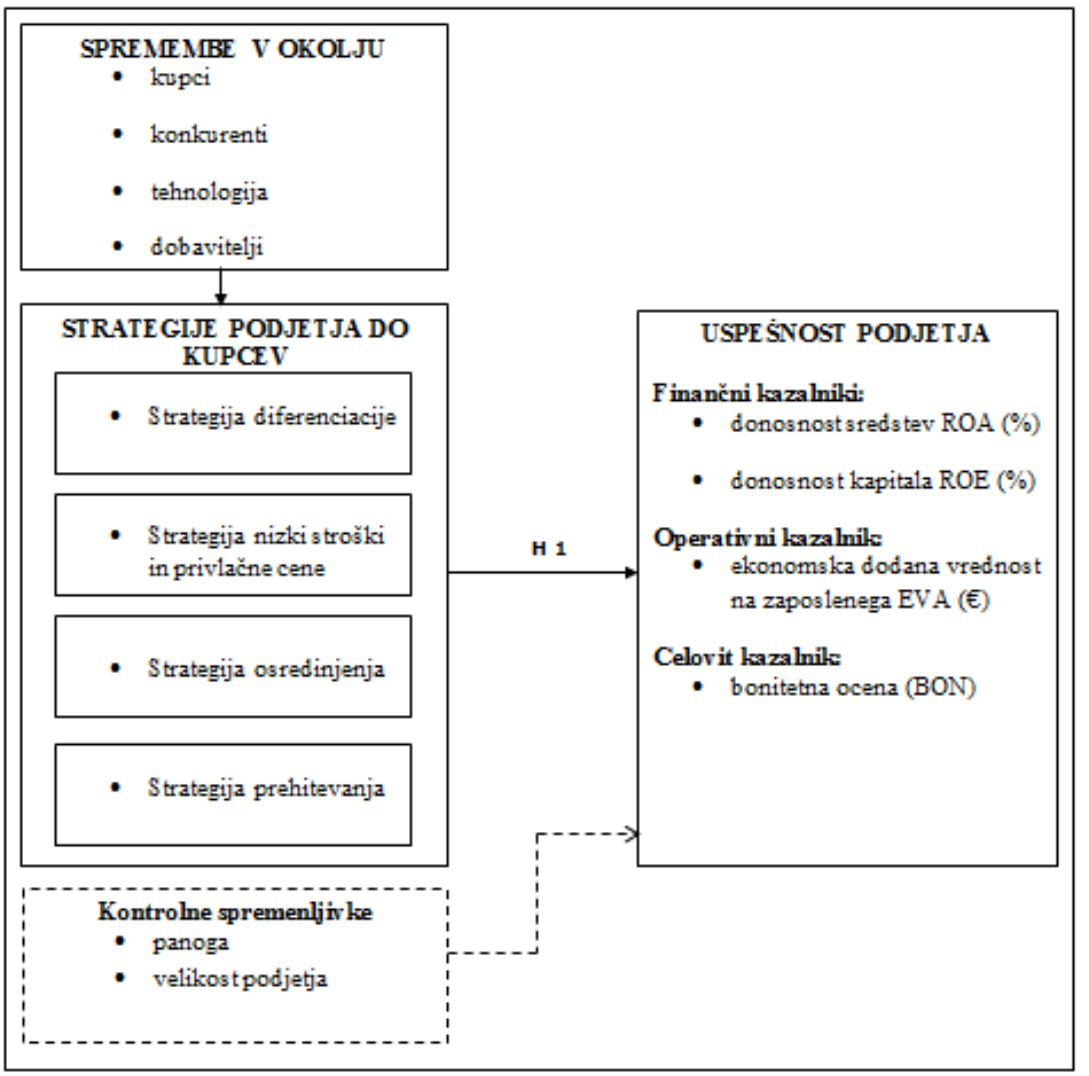

Slika I: Teoretični model povezav

$\mathrm{V}$ nadaljevanju poglavja uvodoma pojasnjujemo uspešnost podjetja, saj posamezne dejavnike in področja $v$ našem modelu povezujemo $z$ uspešnostjo podjetja (slika I). Navajamo definicije uspešnosti različnih av- 
torjev ter izpostavljamo opredelitev uspešnosti podjetja, ki jo bomo mi uporabili za potrebe doseganja ciljev te raziskave v empiričnem delu.

\section{Hipoteza in merski instrument}

Glede na spoznanja v teoretičnem delu raziskave in zasnovan model povezav (slika I) dejavnik »Spremembe v okolju«, dejavnik »Strategije podjetja do kupcev« in uspešnost podjetja povezujemo v sledeči hipotezi:

Hipoteza: Spremembe v okolju vplivajo na izbor strategije podjetja do kupcev, kar rezultira v uspešnosti podjetja. Podjetja, ki uporabljajo strategijo diferenciacije, so uspeřnejša kot tista, ki uporabljajo eno od ostalih strategij (strategijo nizkih stroškov in privlačnih cen, strategijo osredinjenja, strategijo prehitevanja).

V sklopu potrjevanja hipoteze v empiričnem delu raziskave raziskujemo: (I) ali obstajajo statistično značilne povezave med spremembami v okolju podjetja, strategijo podjetja do kupcev in uspešnostjo podjetja; (2) ali hipoteza velja; (3) kaj (katere trditve) v sklopu sprememb v okolju in strategij podjetja do kupcev imajo statistično najznačilnejši vpliv na uspešnost podjetja; (4) na katere kazalnike uspešnosti podjetja (ROA, ROE, EVA, BON) obstaja statistično značilen vpliv; (s) kako močne so te povezave (šibke, močne); (6) kakšna je smer povezav (pozitivna, negativna).

Na podlagi raziskave literature in opisa spoznanj v tem poglavju smo za merjenje povezav med dejavniki v sklopu potrjevanja hipoteze uporabili različne trditve, ki jih predstavljamo v nadaljevanju.

\section{Spremembe v okolju}

Glede na spoznanja v teoretičnem delu raziskave in razvit teoretični model (slika I) za vsako od področij dejavnika »Spremembe zunanjega okolja« uporabljamo trditve, ki so sestavni del našega merskega instrumenta, anketnega vprašalnika (priloga $\mathrm{r}$ ).

V okviru dejavnika »Spremembe v okolju « uporabljamo sklop trdi-

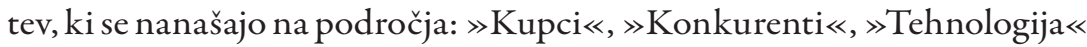
in $\gg$ Dobavitelji $\ll$.

Področje $\gg$ Kupci« v okviru dejavnika »Spremembe v okolju« smo zajeli z naslednjimi trditvami:

- Kupci v naši panogi nenehno zahtevajo nove izdelke/storitve.

- Zahteve kupcev o izdelkih/storitvah se s časom zelo malo spreminjajo. 
- Na nas se obračajo povsem novi kupci, s katerimi še nismo sodelovali.

- Struktura naših kupcev se s časom zelo malo spreminja.

Področje $\gg$ Konkurenti « v okviru dejavnika $\gg$ Spremembe v okolju « smo zajeli z naslednjimi trditvami:

- V našo panogo ves čas vstopajo novi konkurenti.

- Konkurenti v naši panogi pogosto spreminjajo svojo strategijo.

- Tržni deleži med konkurenti v naši panogi se s časom zelo spreminjajo.

- Naš glavni tekmec $\mathrm{v}$ panogi se hitreje prilagaja na spremembe kot mi.

Področje »Tehnologija « v okviru dejavnika »Spremembe v okolju « smo zajeli z naslednjimi trditvami:

- Tehnološke spremembe, ki se dogajajo v naši panogi, so zelo velike.

- Tehnološke spremembe se v naši panogi dogajajo zelo hitro.

- Tehnološke spremembe nam omogočajo veliko novih priložnosti za rast našega podjetja.

- Tehnološki razvoj za nadaljnja 2-3 leta je v naši panogi zelo težko napovedati.

Področje »Dobavitelji « v okviru dejavnika »Spremembe v okolju « smo zajeli z naslednjimi trditvami:

- Naši glavni dobavitelji veljajo za vodilne na svojem področju poslovanja.

- Z našimi glavnimi dobavitelji vzpostavljamo dolgoročna strateška partnerstva.

- Naši glavni dobavitelji se hitro prilagajajo spremembam v panogi.

- Konkurenčnost naših izdelkov/storitev je odvisna predvsem od inovativnosti naših dobaviteljev.

Vsako izmed trditev smo opremili z mersko lestvico po Likertu ter jo vključili v anketni vprašalnik z opisi in navodili za izpolnjevanje, kar predstavlja naš merski instrument za to, in sicer za dejavnik »Spremembe v okolju $\ll$ (priloga $\mathrm{I})$.

Pri razvoju trditev v sklopu dejavnika $\gg$ Spremembe v okolju $\ll$ smo izhajali iz podobnih raziskav na tem področju, kjer so posamezne trditve že bile uporabljene kot del merskega instrumenta (Jaworski in Kohli 
1993; Li in Calantone 1998; Danneels in Sethi 2003; Zhou, Yim in Tse 2005; Strecker 2009).

\section{Strategija podjetja do kupcev}

V okviru dejavnika »Strategija podjetja do kupcev« razvijamo sklop trditev, ki se nanaša na področja: »Strategija diferenciacije«, »Strategija nizkih stroškov in privlačnih cen «, »Strategija osredinjenja « ter »Strategija prehitevanja $\ll$.

Področje »Strategija diferenciacije《 v okviru dejavnika »Strategija podjetja do kupcev« smo zajeli z naslednjimi trditvami:

- Naši izdelki/storitve so bistveno drugačni od našega glavnega tekmeca v panogi.

- Pri trženju smo inovativnejši kot naš glavni tekmec v panogi.

- Stremimo k prepoznavnosti lastne blagovne znamke.

- Več vlagamo v marketinško komuniciranje kot naš glavni tekmec v panogi.

Področje »Strategija nizkih stroškov in privlačnih cen« v okviru dejavnika »Strategija podjetja do kupcev« smo zajeli z naslednjimi trditvami:

- V podjetju smo pri izvajanju poslovnih aktivnosti visoko učinkoviti (produktivni).

- Na trgu konkuriramo z nizkimi cenami naših izdelkov/storitev.

- V procesih podjetja nenehno poudarjamo zniževanje vseh vrst stroškov poslovanja.

- Pri iskanju stroškovno najugodnejših virov (materialov, energije, znanja ipd.) na trgu smo zelo uspešni.

Področje »Strategija osredinjenja « v okviru dejavnika »Strategija podjetja do kupcev« smo zajeli z naslednjimi trditvami:

- Z našimi izdelki/storitvami ciljamo na ozek segment kupcev.

- Na trgu ponujamo ožji nabor izdelkov/storitev kot naša konkurenca.

- Na trgu ponujamo izdelke/storitve v ozkem cenovnem segmentu.

- Na trgu ponujamo specialne/nišne izdelke/storitve.

Področje $\gg$ Strategija prehitevanja $\ll$ v okviru dejavnika $\gg$ Strategija podjetja do kupcev« smo zajeli z naslednjimi trditvami:

- Nove potrebe trga zaznamo hitreje kot naš glavni tekmec. 
- Nove izdelke/storitve na trg uvajamo hitreje kot naš glavni tekmec.

- Pri uvajanju sprememb v naše poslovanje smo hitrejši kot naš glavni tekmec.

- Spremembe v panogi sprožamo hitreje kot naš glavni tekmec.

Vsako izmed trditev smo opremili z mersko lestvico po Likertu in jo vključili v anketni vprašalnik z opisi in navodili za izpolnjevanje, kar predstavlja naš merski instrument za dejavnik »Strategija podjetja do kupcev« (priloga I).

Pri razvoju trditev v sklopu dejavnika »Strategija podjetja do kupcev« smo izhajali iz podobnih raziskav na tem področju, kjer so posamezne trditve že bile uporabljene kot del merskega instrumenta (Jaworski in Kohli 1993; Li in Calantone 1998; Danneels in Sethi 2003; Zhou, Yim in Tse 2005; Strecker 2009).

\section{Uspešnost podjetja}

Merjenje uspešnosti podjetja ni povsem preprosto, saj gre za splet okoliščin in pogledov nanjo (Markič 2003, I35-137). Obstoječi načini merjenja uspešnosti podjetja, ki so temeljili samo na finančnem vidiku, postopoma ne ustrezajo več merilom in standardom uspešnosti v sodobnem družbenem in poslovnem okolju. Za merjenje uspešnosti Nandakumar, A. Ghobadian in O'Regan $(2009,250)$ pravijo, da je smiselno, da uspešnost podjetja merimo s stopnjo doseganja ciljev (finančni vidik) in tudi relativno glede na konkurenco. Za merjenje uspešnosti tudi Allen in $M$. M. Helms (2006, 438) predlagata, da vključimo tako finančne kazalnike (kot sta dobiček in ekonomska dodana vrednost) kakor tudi nefinančne kazalnike (kot je inovativnost) (Goldsmith in Clutterbuck 1984; Strecker 2009; Delgado idr. 2014). Kotabe, Srini in Aulakh (2002) predlagajo, da pri merjenju uspešnosti podjetja zajamemo tako primarne kot sekundarne podatke in da zajamemo časovno dimenzijo vsaj zadnjih petih let poslovanja podjetja (Kotabe, Srini in Aulakh 2002 v Hult idr. 2008, 1072-1073; Strecker 2009, 219-224). Merjenje uspešnosti podjetja lahko izvedemo s pomočjo že znanih modelov, prav tako pa lahko razvijemo nove specifične modele. Taticchi, Tonelli in Cagnazzo (2010, I4) predlagajo, da za MSP, ki predstavlja tudi našo populacijo, razvijemo svoj model povezav in kazalnikov za merjenje vplivov na uspešnost podjetja.

Uspešnost MSP bomo v našem primeru merili na celovit način, s pomočjo sekundarnih podatkov (ROA, ROE, EVA, in BON). Vključili bomo časovno dimenzijo za zadnjih pet let poslovanja. Za pridobivanje 
podatkov o uspešnosti podjetja bomo uporabili poslovno bazo GVIN, ki je javna spletna baza podatkov o poslovanju podjetij in omogoča celovit vpogled v položaj podjetij na slovenskem trgu (GVIN 20r8a).

ROA in ROE sta kazalnika donosnosti (rečemo tudi rentabilnosti), s katerima analiziramo uspešnost poslovanja podjetja. Stopnja donosnosti pomeni izraženo razmerje med donosi in vlaganji, pomnoženo s sto (Bojnec idr. 2007, 239). Poslovna donosnost sredstev (dobičkovnost sredstev, ROA) nam pokaže uspešnost uporabe sredstev podjetja. Računamo jo na letni ravni. Na podlagi tega kazalnika lahko ugotovimo, kako podjetje posluje (BISNODE b. 1.). Stopnja ROA je razmerje med čistim dobičkom in sredstvi, pomnoženo $s$ sto, in nam pove, koliko odstotkov od vrednosti sredstev predstavlja vrednost ustvarjenega čistega dobička. Ta kazalnik ne upošteva lastniške strukture sredstev, saj upoštevamo le skupno vrednost vseh sredstev, ne lastniške pripadnosti sredstev (Bojnec idr. 2007, 24I). Na kazalnik ROA je treba biti pozoren, saj je čisti poslovni izid obračunskega obdobja mnogokrat podrejen kreativnemu računovodstvu. Na podjetje z zelo visokim ROA in hkrati zelo visoko vrednostjo kazalnika delež dolga $\mathrm{v}$ financiranju moramo biti pozorni, saj to pomeni, da podjetje uspešnost povečuje na račun zadolževanja (BISNODE b. 1.). Lastnosti kazalnika ROA so naslednje: (I) Višja kot je vrednost kazalnika ROA, boljše je in donosnejše je podjetje ter učinkoviteje uporablja lastna sredstva. (2) Dejavnosti, ki poslujejo z nižjo vrednostjo sredstev, bodo imele višjo vrednost ROA. Primer so storitvene dejavnosti. (3) Negativna vrednost ROA pomeni, da podjetje posluje slabo (negativno). (4) Vrednost ROA ena ali več pomeni, da podjetje običajno posluje z nizko vrednostjo sredstev ter $\mathrm{z}$ dobičkom, ki ima vrednost enako ali večjo od zabeleženih sredstev. Takšno vrednost tega kazalnika imajo običajno podjetja, ki delujejo v dejavnosti, kjer ne potrebujejo veliko sredstev za poslovanje. Primer so storitvene dejavnosti. (s) Se ne izračuna v primeru, ko $\mathrm{v}$ imenovalcu nastopi vrednost nič. To pomeni, da podjetje posluje brez sredstev. (6) ROA ima vrednost nič v primeru, ko podjetje izkazuje dobiček v vrednosti nič (BISNODE b. 1.).

Zaradi vsega navedenega je za uspešnost podjetja treba hkrati analizirati tudi druge kazalnike, kot je kazalnik ROE.

ROE pomeni donosnost (dobičkovnost) kapitala. Je razmerje med čistim dobičkom in kapitalom, pomnoženo s sto. Pove nam, koliko odstotkov od vrednosti kapitala predstavlja vrednost ustvarjenega čistega dobička. ROE mora biti načeloma višji od bančnih obresti. Kazalnik ROE je $t$. i. mati vseh kazalnikov uspešnosti podjetja. Podjetje oz. investicija lahko vrednost za lastnika ustvari samo, če je ROE večji, kot je strošek kapita- 
la. Prav zaradi tega je donosnost kapitala ena izmed najbolj uporabljanih in najpomembnejših mer profitabilnosti z vidika lastnika. Rastoči ROE nakazuje, da podjetje povečuje svojo sposobnost ustvarjati dobiček brez potrebe po dodatnem kapitalu in da učinkovito uporablja lastniški kapital. Večji ROE pomeni višji donos. Velja tudi nasprotno: padajoči ROE predstavlja manj donosno investicijo (»Donos na kapital - ROE « b. 1.).

EVA je ekonomska dodana vrednost. Koncept je osnovan na cilju poslovanja podjetja, da doseže dolgoročno rast vrednosti enote lastniškega kapitala (npr. delnice) (Lukežič 2000, 5). EVA se izračuna tako, da neto dobiček podjetja zmanjšamo za primerno vrednost vseh oportunitetnih stroškov celotnega kapitala, investiranega v podjetje. Meri se v EUR. Ponavadi ga analiziramo na letni ravni. EVA je povezana z merjenjem celotne produktivnosti podjetja in neposredno izpostavi številne načine, na katere bi bilo mogoče izboljšati učinkovitost podjetij. Managementu podjetij omogoča, da zavzame vidik lastnikov in da sprejme takšne odločitve, da izpolni njihova pričakovanja. EVA managementu nakazuje usmeritve, da bi bilo treba: (I) povečati dobiček, brez angažiranja večje količine kapitala; (2) uporabljati manj kapitala oz. zmanjšati stroške kapitala; (3) povečati investicije v projekte, ki ustvarjajo večje stopnje donosa, kot znašajo njihovi stroški kapitala; in (4) zmanjšati investicije v projekte, ki ustvarjajo manjše stopnje donosa (Bolčič i999, II; Gruban b. l., I).

$\mathrm{BON}$ pomeni bonitetno oceno poslovanja podjetja. Za vlagatelje in partnerje podjetja pove, kako tvegano je poslovanje $\mathrm{z}$ izbranim podjetjem. Bonitetna ocena (BON) temelji na računovodskih izkazih subjektov za zadnje poslovno leto in napoveduje varnost poslovanja $v$ naslednjih dvanajstih mesecih. Ocena BON se ponavadi pripravlja na letni ravni. Za oceno $\mathrm{BON}$ smo uporabili podatke iz GVIN, kjer je BON sestavljen iz finančne ocene (A - najboljše; B, C, D, E - najslabše), ocene kazalnika (I - najboljše; 2, 3 - najslabše) in dinamične napovedi (++ - najboljše; +, -, - - - najslabše). Na BON vplivajo dejavnost podjetja, lokacija, tožbe, blokade računov, plačilni indeks in finančni podatki (GVIN 2018a). Dinamična ocena pri izračunu upošteva tako pretekle spremembe $\mathrm{v}$ podjetju kakor tudi tekoče, vsakodnevne spremembe, zato se lahko spreminja dnevno (BISNODE b. 1.). Podjetja z najboljšim BON imajo oceno A $\mathrm{I}++$.

\section{Način potrjevanja hipoteze}

Hipotezo smo preverjali s pomočjo linearnih strukturnih modelov (SEM), pri čemer smo uporabili metodo analize poti (angl.path analysis). Spremembe v okolju podjetja smo merili prek vpliva kupcev, konkurentov, tehnologije in dobaviteljev. Pokazatelj sprememb v zunanjem okolju 
je bila ocenjena stopnja strinjanja anketirancev s posamezno trditvijo na šeststopenjski Likertovi lestvici (priloga I).

Uporabo strategije podjetja do kupcev smo merili z ocenjeno stopnjo strinjanja anketirancev $s$ posamezno trditvijo. Zajeli smo naslednje strategije do kupcev: strategija diferenciacije, strategija nizkih stroškov in privlačnih cen, strategija osredinjenja in strategija prehitevanja. Pokazatelj uporabe posamezne strategije je bila ocenjena stopnja strinjanja anketirancev s posamezno trditvijo na šeststopenjski Likertovi lestvici (priloga I).

$\mathrm{Na}$ podlagi teoretičnih izhodišč ter skladno z namenom in s cilji naloge smo oblikovali model povezav (slika I) ter razvili hipotezo. Za vsakega izmed dejavnikov: (I) »Spremembe v okolju«, ki vključuje področja

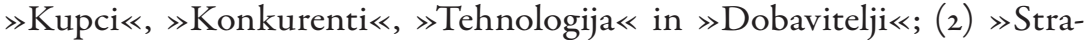
tegija podjetja do kupcev«, ki vključuje področja »Strategija diferenciacije «, 》Strategija nizkih stroškov in privlačnih cen «, »Strategija osredinjenja « ter $\gg$ Strategija prehitevanja «, smo uporabili trditve, ki so bile podlaga za oblikovanje anketnega vprašalnika za potrebe empiričnega dela raziskave (priloga I). Merjenje uspešnosti podjetja smo glede na preučeno literaturo in vire zasnovali na celovit način, s pomočjo sekundarnih podatkov o finančni uspešnosti (kazalnik donosnosti sredstev - ROA; kazalnik donosnosti kapitala - ROE), operativni uspešnosti (kazalnik ekonomske dodane vrednosti - EVA) ter kazalnik BON (bonitetna ocena poslovanja podjetja) za daljše časovno obdobje. Takšen način merjenja smo zasnovali glede na spoznanja iz literature, saj delni pogledi na uspešnost podjetja ob upoštevanju le enega kazalnika lahko prikažejo izkrivljeno sliko o uspešnosti podjetja.

Glede na uvodne opredelitve problema, razvito hipotezo in zasnovani model povezav med dejavnikoma $(\mathrm{I}) \gg$ Spremembe v okolju $\ll$ in (2) $\gg$ Strategija podjetja do kupcev« ter uspešnostjo podjetij prehajamo v osrednji, empirični del raziskave, kjer predstavljamo potek izvedbe raziskave, analize zbranih podatkov ter rezultate raziskave s komentarji po posameznih področjih. 



\section{Rezultati empirične raziskave}

V tem poglavju predstavljamo rezultate raziskave. Rezultati osrednje empirične raziskave v prvem delu vsebujejo: opis ciljne populacije, način zbiranja podatkov, opis vzorca, opis testiranja veljavnosti in zanesljivosti merskega instrumenta ter podroben opis uporabljenih metod analize podatkov. V nadaljevanju predstavljamo opisno statistiko rezultatov raziskave za: (I) dejavnik »Spremembe v okolju «, kamor smo umestili pod-

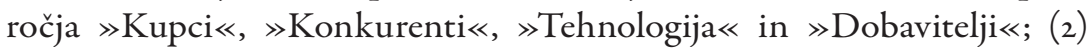
dejavnik $\gg$ Strategija podjetja do kupcev«, kamor smo umestili področja »Strategija diferenciacije«, »Strategija nizkih stroškov in privlačnih cen $\ll, ~ \gg$ Strategija osredinjenja $\ll$ ter $\gg$ Strategija prehitevanja $\ll$.

$\mathrm{Na}$ koncu empiričnega dela so predstavljeni rezultati preverjanja veljavnosti teoretičnega modela (slika I) s komentarji. Rezultate predstavljamo s pomočjo preglednic, opisov in komentarjev v tekstu ter preglednic v prilogah.

\section{Opis poteka zbiranja in analize podatkov}

V nadaljevanju predstavljamo podroben opis poteka raziskave. Opisujemo ciljno populacijo, metode zbiranja podatkov, vzorec podjetij, metode analize podatkov ter način testiranja merskega inštrumenta.

\section{Opis ciljne populacije}

Ciljna populacija v naši raziskavi so bila MSP, ki so bila v času naše raziskave na dan II. I. $2017 \mathrm{~V}$ javni bazi podatkov o poslovnih subjektih $s$ sedežem na območju Republike Slovenije (AJPES). AJPES je Agencija 
Republike Slovenije za javnopravne evidence in storitve, ki je pooblaščena za zbiranje, obdelovanje in posredovanje podatkov iz letnih poročil poslovnih subjektov ter za javno objavljanje letnih poročil in drugih podatkov gospodarskih družb, samostojnih podjetnikov in drugih poslovnih subjektov (AJPES b. 1.). Zahtevek za pridobitev kontaktnih podatkov o podjetjih smo na AJPES podali I0. I. 2017. Seznam podjetij smo od AJPES pridobili v elektronski obliki I I. I. 2017. MSP je bilo 3.236.

V raziskavo smo vključili samostojne podjetnike (s. p.), družbe z omejeno odgovornostjo (d. o. o.), družbe z neomejeno odgovornostjo (d. n. o.) in delniške družbe (d. d.). Podjetij v likvidaciji, stečaju in prisilni poravnavi nismo vključili. Prav tako nismo vključili javnih agencij, sodišč, notarjev, odvetnikov, upravnih enot ipd., saj ti niso bili naša ciljna populacija. Na trgu imajo namreč poseben položaj in za njih $\mathrm{v}$ javno dostopnih bazah ni popolnih podatkov o uspešnosti poslovanja. Pridobljeni podatki o preostalih MSP (spletna pošta podjetij) v bazi AJPES so bili nepopolni, zato smo naslove spletne pošte za podjetja naknadno poiskali sami s pomočjo javnih objav na spletu. V bazi je ostalo skupaj 3.007 MSP, za katere smo našli javno objavljene naslove e-pošte, kar je predstavljalo naš vzorčni okvir. $Z$ uvodnim nagovorom in prošnjo za sodelovanje v raziskavi smo se po elektronski pošti direktno obrnili na direktorje podjetij.

\section{Uporabljene metode zbiranja podatkov}

Za zbiranje podatkov smo uporabili spletni anketni vprašalnik (priloga I). Razvili smo ga s pomočjo pregleda literature $v$ teoretičnem delu raziskave. Vprašalnik je bil sestavljen iz vprašanj zaprtega tipa.

Anketni vprašalnik bil sestavljen iz več tematskih sklopov. V uvodu so bili spremni dopis za direktorje podjetij, razlaga o raziskavi in navodila za izpolnjevanje. Prvi sklop je obravnaval dejavnik »Spremembe okolja podjetja « (kupci, konkurenti, tehnologija, dobavitelji) in dejavnik »Strategija podjetja do kupcev« (strategija diferenciacije, strategija nizki stroški in privlačne cene, strategija osredinjanja, strategija prehitevanja). V drugem sklopu smo zajeli podatke o podjetju in anketirancu (uspešnost podjetja glede na glavnega tekmeca $\mathrm{v}$ panogi, panoga, število zaposlenih, statusna oblika podjetja, dosežena najvišja stopnja izobrazbe anketiranca, trenutna funkcija anketiranca v podjetju, ime podjetja).

Najpomembnejše, zadnje vprašanje se je nanašalo na ime podjetja. Potrebovali smo ga zaradi naknadnega pridobivanja aktualnih sekundarnih podatkov o ROA, ROE, EVA in BON. Sekundarne podatke smo pridobili sami iz poslovne baze GVIN za zadnjih pet let poslovanja za tista podjetja, ki so v celoti izpolnila anketni vprašalnik. 
Vprašalnik je bil sestavljen iz vprašanj zaprtega tipa. $Z$ vidika vrste vprašanj smo vključili vprašanja o dejstvih. Anketiranci so podajali ocene strinjanja s podanimi trditvami. Da smo omogočili čim večjo razlikovanje odgovorov, smo se izognili uporabi odgovorov vrste $\gg$ da $\ll$ in $\gg n e \ll$. Uporabili smo šeststopenjsko Likertovo lestvico, da smo se izognili odgovorom na srednji vrednosti lestvice (Easterby-Smith, Thorpe in Lowe 2007, 166).

Spremenljivke, ki smo jih vključili v vprašalnik, so bile ordinalne, številske in nominalne. Ordinalna spremenljivka omogoča kvečjemu ureditev enot po velikosti. Ordinalne (lestvica od I-6) smo uporabili za merjenje sprememb v okolju in strategije podjetja do kupcev. Številske spremenljivke omogočajo ureditev po vrednosti. Uporabili smo jih pri merjenju finančne uspešnosti podjetja, kar smo merili z ROA, ROE in EVA. Nominalne spremenljivke omogočajo razlikovanje med vrednostmi samo z enakostjo ali neenakostjo (Košmelj 200I, 239-245). Uporabili smo jih za merjenje celovite uspešnosti podjetja, kar smo merili z BON.

\section{Testiranje veljavnosti in zanesljivosti merskega instrumenta}

Merski instrument smo razvili s pomočjo pregleda literature, njegovo zasnovo pa predstavili v poglavju »Teoretični model povezav med dejavniki, hipoteza in merski instrument «. Vprašalnik (priloga I) smo oblikovali v spletni obliki s pomočjo spletne aplikacije $\mathrm{I} K A$, ki je odprtokodna aplikacija za spletno anketiranje.

Zanesljivost vprašalnika smo preverili s pomočjo Cronbachovega koeficienta alfa $(\alpha)$, ki je namenjen merjenju notranje konsistentnosti merskega instrumenta (Easterby-Smith, Thorpe in Lowe 2007, 166). Pred pošiljanjem $\mathrm{v}$ podjetja smo vprašalnik dodatno predhodno testirali $\mathrm{v}$ akademskem okolju. Obrnili smo se na pet raziskovalcev s področja managementa in raziskovalne metodologije, od katerih smo pridobili koristne predloge izboljšav vprašalnika. Te so se nanašale na jasnost zapisanega, navodila za izpolnjevanje, strukturo in zaporedje tematskih sklopov. Predloge smo upoštevali in jih vključili v izboljšano verzijo vprašalnika. Testiranje delovanja spletne aplikacije optimiranega vprašalnika v elektronski obliki v $\mathrm{IKA}$ z izpolnjevanjem vsebine vprašalnika in testiranje shranjevanja zbranih podatkov smo izvajali do I2. 6. 2017.

Veljavnost vprašalnika smo zagotovili z razvojem primernih pokazateljev za merjenje posameznih vplivov in povezav $s$ spoznanji v teoretičnem delu raziskave. Veljavnost se nanaša na to, koliko smo prepričani, da merski instrument (anketni vprašalnik) dejansko meri to (pojav), kar naj bi meril (Easterby-Smith, Thorpe in Lowe 2007, 168). Empirično smo na 
vsakem tematsko povezanem sklopu uporabili faktorsko analizo in tako dodatno preverili, ali spremenljivke (naše trditve) zares merijo enak dejavnik (faktor).

Rezultati veljavnosti po posameznih dejavnikih so prikazani v skupni preglednici Cronbachovih koeficientov alfa (priloga 6), ki so opisani pri vsakem od dejavnikov v nadaljevanju empiričnega dela.

\section{Vzorec anketiranih podjetij}

Pošiljanje vabil na spletne naslove 3.007 MSP v Sloveniji se je začelo i4. 6. 2017. Spletna anketa je bila odprta do 9. 9. 2017. S pomočjo službe za informatiko Fakultete za management smo v času od I4. 6. 2017 do 9. 9. 2017 vabilo za sodelovanje vsem podjetjem $\mathrm{v}$ raziskavi poslali trikrat. Oddanih je bilo skupaj 318 anket (delno in popolno izpolnjenih). Večina izmed njih se je prekinila ob zadnjem vprašanju, ko smo anketirance prosili za ime podjetja. V bazi zbranih anket je ostal vzorec i63 anket podjetij s popolnimi odgovori, vključno z imenom podjetja. Od tega je bilo 73 majhnih podjetij $(44,8 \%)$ in $90(55,2 \%)$ srednjih podjetij. Glede na vzorčni okvir 3.007 podjetij to predstavlja 5,42-odstotno stopnjo odzivnosti, kar je podoben odziv kot pri podobnih raziskavah v regiji (Hernaus, Bosilj-Vukšić in Indihar-Štemberger 2016; Hernaus, Pejić Bach in Bosilj Vukšič 2oı 2).

\section{Uporabljene metode analize podatkov}

Zbrane podatke smo s pomočjo statističnega programa SPSS (verzija 24.00) analizirali z naslednjimi metodami:

- korelacijska analiza,

- multipla regresijska analiza,

- modeliranje strukturnih enačb - SEM,

- eksploratorna faktorska analiza.

V empiričnem delu za vsakega izmed dejavnikov v našem modelu (slika I) prikazujemo rezultate s pomočjo naslednjih prikazov:

- Povezanost (korelacija) med spremenljivkami oz. trditvami znotraj dejavnika, ki ga v fazi statistične analize poimenujemo faktor, analiziramo in prikažemo $s$ pomočjo:

- Kaiser-Maier-Oaklinovega testa (KMO),

- Bartlettovega testa,

- determinante. 
- Komunalitete, ki prikazujejo delež variance opazovanih spremenljivk, ki jo lahko pripišemo skupnemu faktorju oz. celotni varianci.

- Celotna pojasnjena varianca, ki prikazuje delež ohranjene variabilnosti, ko spremenljivko združimo v en faktor (ko so trditve dovolj povezane, je lahko ena spremenljivka na novo).

- Kolenski diagram, ki kaže optimalno število faktorjev za izločitev (tistih, ki so relevantni).

- Matrika faktorskih uteži, ki kaže, v kolikšni meri posamezna spremenljivka znotraj dejavnika prispeva $\mathrm{k}$ skupnemu vplivu.

- Determinanta nam pokaže, ali posamezne spremenljivke morda ne merijo enega in istega (problem multikolinearnosti).

- Interna konsistentnost (Cronbachova alfa - $\alpha$ ), ki prikazuje zanesljivost (ponovljivost rezultatov ob podobnih podatkih). S testom smo tako preverili stabilnost podatkov.

- Koeficient asimetrije, ki kaže porazdelitev spremenljivke, ki je lahko asimetrična v desno oz. pozitivna asimetrija (če je vrednost koeficienta večja od nič), simetrična oz. normalna porazdelitev (če je vrednost koeficienta enaka nič) ali asimetrična v levo oz. negativna asimetrija (če je vrednost koeficienta manjša od nič). Vrednost koeficienta, večja od o,20, kaže na veliko asimetrijo (Tavakol in Dennick 201 1, 53).

- Koeficient sploščenosti: kaže, ali je spremenljivka koničasta (če je vrednost koeficienta večja od o), normalna (če je vrednost koeficienta enaka o) ali sploščena (če je vrednost koeficienta manjša od o). Vrednost koeficienta nad o,8 kaže na veliko oz. nenormalno sploščenost (Tavakol in Dennick 20I I, 53).

Značilnosti vzorca, povprečne vrednosti in standardne odklone smo prikazali s pomočjo deskriptivne statistične analize.

\section{Opisna statistika rezultatov raziskave}

Začenjamo predstavitev rezultatov empirične raziskave, pri čemer uvodoma predstavljamo podatke o podatkih podjetij, ki smo jih zajeli v vzorec: splošne podatke o anketiranih podjetjih, o panogi, v kateri delujejo podjetja, o velikosti podjetij ter o izobrazbi in funkciji, ki jo opravljajo anketiranci, ki so izpolnjevali vprašalnik. $\mathrm{V}$ nadaljevanju predstavljamo deskriptivno statistiko podatkov, pridobljenih na podlagi vzorca 163 ustrezno izpolnjenih vprašalnikov. 


\section{Rezultati analize vzorca podjetij}

Najprej predstavljamo podatke, ki so jih anketiranci podali o podjetjih, v katerih so zaposleni. Za klasifikacijo panog smo uporabili standardno klasifikacijo dejavnosti (SKD) podjetij (Statistični urad Republike Slovenije 20I0). Iz preglednice I je razvidno, da največ podjetij (37,4 \%) posluje v predelovalni dejavnosti, druga najpogosteje zastopana panoga (ıo,4 $\%), v$ kateri poslujejo podjetja, je trgovina, vzdrževanje in popravila motornih vozil.

\section{Preglednica ı: Panoga, v kateri posluje podjetje}

\begin{tabular}{lcc} 
Panoga, v kateri posluje podjetje & Frekvenca & Delež $(\%)$ \\
\hline Kmetijstvo in lov, gozdarstvo, ribištvo & 10 & 6,1 \\
Predelovalne dejavnosti (proizvodnja itd.) & 61 & 37,4 \\
Oskrba z električno energijo, plinom in paro & 2 & 1,2 \\
Oskrba z vodo, ravnanje zodplakami in odpadki, saniranje okolja & 6 & 3,7 \\
Gradbeništvo & II & 6,7 \\
Trgovina, vzdrževanje in popravila motornih vozil & 17 & 10,4 \\
Promet in skladiš̌cnje & 7 & 4,3 \\
Gostinstvo & 2 & 1,2 \\
Informacijske in komunikacijske dejavnosti & 7 & 4,3 \\
Strokovne, znanstvene in tehnične dejavnosti & 9 & 5,5 \\
Druge raznovrstne dejavnosti (svetovanje itd.) & 2 & 1,2 \\
Izobraževanje & 2 & 1,2 \\
Zdravstvo in socialno varstvo & 2 & 1,2 \\
Drugo & 25 & 15,3 \\
\hline Skupaj & 163 & 100,0 \\
\hline
\end{tabular}

V preglednici 2 opazimo, da je glede na povprečno število zaposlenih v podjetjih v letu 2016 večji delež ( $55,2 \%)$ srednjih podjetij, preostali del $(44,8 \%)$ pa predstavljajo majhna podjetja (preglednica 2). Pri proizvodnih podjetjih, ki jih je največ, v našem vzorcu opažamo, da so to podjetja, ki proizvajajo sklope, polizdelke za druga podjetja ( $80 \%)$ in so vpeta $\mathrm{v}$ dobaviteljsko verigo večjih podjetij. $20 \%$ podjetij, ki se ukvarjajo $s$ proizvodnjo, je takšnih, ki proizvajajo končni izdelek in ga prodajajo končnemu potrošniku (kupcu). To je pomembno za nadaljnjo interpretacijo rezultatov $\mathrm{v}$ empiričnem delu raziskave. 
Povprečno število zaposlenih v podjetju

Frekvenca

$\operatorname{Delež}(\%)$

od Io do 49 (majhno podjetje)

73

od 50 do 249 (srednje podjetje)

44,8

Skupaj

90

55,2

163

100,0

Kot prikazuje preglednica 3, ima 47,2 \% anketirancev dodiplomsko višješolsko, visokošolsko ali univerzitetno (bolonjsko UN) izobrazbo, 28,2 \% jih ima dodiplomsko univerzitetno (stari program) izobrazbo ali bolonjski strokovni magisterij, ı , о \% anketirancev poklicno ali srednješolsko izobrazbo, I o, 4 \% jih ima znanstveni magisterij (stari program), 3,I \% jih ima doktorat znanosti.

Preglednica 3: Dosežena najvišja stopnja izobrazbe anketiranca

\begin{tabular}{lcc} 
Dosežena najvišja stopnja izobrazbe anketiranca & Frekvenca & Delež (\%) \\
\hline $\begin{array}{l}\text { Poklicna ali srednješolska izobrazba } \\
\begin{array}{l}\text { Dodiplomska višješolska, visokošolska ali univerzitetna } \\
\text { (bolonjska UN) }\end{array}\end{array}$ & 18 & 47,2 \\
$\begin{array}{l}\text { Dodiplomska univerzitetna (stari program) } \\
\text { ali strokovni magisterij (bolonjski) }\end{array}$ & 46 & 28,2 \\
$\begin{array}{l}\text { Znanstveni magisterij (stari program) } \\
\text { Doktorat znanosti (preǰ̌nji ali bolonjski B3) }\end{array}$ & 17 & 10,4 \\
\hline Skupaj & 5 & 3,1 \\
\hline
\end{tabular}

Iz preglednice 4 je razvidno, da 35,0 \% anketirancev v podjetju opravlja funkcijo direktorja ali vodje poslovne funkcije, 27,0 \% je generalnih direktorjev, 7,4 \% anketirancev opravlja funkcijo skrbnika procesa, 4,3\% vodje projektov za izboljšave procesov, 2,5\% funkcijo tehničnega direktorja (preglednica 6). Kar 23,9\% anketirancev ne opravlja nobene izmed podanih funkcij, temveč so večinoma zaposleni kot člani timov in sodelavci pri projektih.

Čeprav smo vprašalnike naslovili na direktorje podjetij, so jih izpolnjevali tudi njihovi sodelavci, ki so povezani $\mathrm{z}$ izboljšavami procesov $\mathrm{v}$ podjetju. To smo ob začetku raziskave predvideli in $\mathrm{v}$ sklop vprašanj o anketirancih v anketo vključili tudi nabor različnih možnosti o tem, katero funkcijo opravljajo anketiranci. Glede na spoznanja v teoretičnem delu naloge o lastnostih MSP smo predvidevali, da ankete ne bodo izpolnjevali samo direktorji. 


\begin{tabular}{lcc} 
Trenutna funkcija anketiranca v podjetju & Frekvenca & Delež (\%) \\
Generalni direktor & 44 & 27,0 \\
Tehnični direktor & 4 & 2,5 \\
Direktor ali vodja poslovne funkcije (enote, oddelka, sektorja) & 57 & 35,0 \\
Skrbnik procesa & 12 & 7,4 \\
Vodja projektov za izboljšave procesov & 7 & 4,3 \\
Drugo & 39 & 23,9 \\
\hline Skupaj & 163 & 100,0 \\
\hline
\end{tabular}

\section{Rezultati ocen za dejavnik »Spremembe v okolju«}

$\mathrm{V}$ tem poglavju predstavljamo rezultate drugega sklopa anketnega vprašalnika, pri čemer smo anketirance povprašali po dejavnikih sprememb v okolju za primer njihovega podjetja. Glede na razviti model (slika I) smo v dejavnik »Spremembe v okolju « podjetja vključili področja $\gg$ Kupci«,

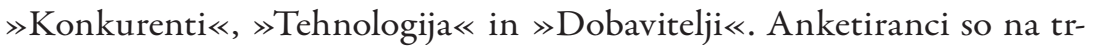
ditve, ki smo jih razvili s pomočjo spoznanj v teoretičnem delu raziskave, odgovarjali s pomočjo šeststopenjske lestvice, s katero so ocenili, v kolikšni meri posamezna trditev drži za primer njihovega podjetja. Pri tem je ocena I pomenila, da trditev za podjetje nikakor ne drži, ocena 6 pa, da trditev za podjetje zelo drži. Skupno povprečje posameznih trditev smo izračunali tako, da smo sešteli povprečne vrednosti posameznih trditev in vsoto delili s številom trditev. Za vsako izmed trditev smo izračunali povprečja, standardne odklone ter vrednosti koeficientov asimetrije in sploščenosti.

Koeficient asimetričnosti kaže, ali so odgovori anketirancev za posamezni dejavnik v povprečju bolj proti oceni I, kar na naši lestvici pomeni nestrinjanje $s$ trditvijo (negativna vrednost koeficienta asimetričnosti, v levo), ali bolj proti oceni 6 , kar na naši lestvici pomeni strinjanje s trditvijo (pozitivna vrednost koeficienta asimetričnosti, v desno). Koeficient sploščenosti kaže, kako enakomerno so pri posameznem dejavniku porazdeljeni odgovori anketirancev na naši lestvici (I-6). Negativne vrednosti koeficienta sploščenosti pomenijo večjo sploščenost (ni ekstremnih odstopanj v porazdelitvi odgovorov). Grafični prikazi koeficientov asimetričnosti za vsak posamezen dejavnik so prikazani v prilogi 4 .

$\mathrm{Na}$ podlagi prikazanih vrednosti v preglednici 5 ugotavljamo, da so anketiranci za dejavnik »Spremembe v okolju « na področju »Kupci« v povprečju najvišjo oceno $(4,34)$ dodelili trditvi, da kupci v njihovi pano- 
gi nenehno zahtevajo nove izdelke oz. storitve, najnižjo povprečno oceno $(3,07)$ pa ima trditev, da se zahteve kupcev o izdelkih oz. storitvah s časom zelo malo spreminjajo. Relativno visoko oceno so anketiranci v povprečju podali tudi pri drugih trditvah. Standardni odkloni trditev se gibljejo od I,224 do I,395.

Preglednica s: Rezultati ocen za dejavnik $»$ Spremembe v okolju « - področje $»$ Kupci «

\begin{tabular}{lcccc} 
Trditev & $\begin{array}{c}\text { Povprečna } \\
\text { vrednost } \\
(\mathbf{I}-6)\end{array}$ & $\begin{array}{c}\text { Standardni } \\
\text { odklon }\end{array}$ & $\begin{array}{c}\text { Koef. } \\
\text { asimetričnosti }\end{array}$ & $\begin{array}{c}\text { Koef. } \\
\text { sploščenosti }\end{array}$ \\
$\begin{array}{l}\text { Kupciv naši panogi nenehno zahtevajo } \\
\text { nove izdelke/storitve. }\end{array}$ & 4,34 & 1,394 & $-0,482$ & $-0,654$ \\
$\begin{array}{l}\text { Zahteve kupcev o izdelkih/storitvah se s } \\
\text { časom zelo malo spreminjajo. }\end{array}$ & 3,07 & $\mathbf{1}, 395$ & 0,337 & $-0,661$ \\
$\begin{array}{l}\text { Na nas se obračajo povsem novi kupci, s } \\
\text { katerimi še nismo sodelovali. }\end{array}$ & 3,39 & 1,224 & 0,205 & $-0,587$ \\
$\begin{array}{l}\text { Struktura naših kupcev se s časom zelo } \\
\text { malo spreminja. }\end{array}$ & 3,75 & $\mathbf{1 , 2 7 7}$ & 0,003 & $-0,834$ \\
\hline \begin{tabular}{l} 
Povprečje kupci \\
\hline
\end{tabular} & 3,64 & & & \\
\hline
\end{tabular}

Za dejavnik »Spremembe v okolju« na področju »Kupci« so koeficienti asimetričnosti pri večini trditev pozitivni, kar nakazuje na asimetrijo v desno. Izjema je le ena trditev $\mathrm{z}$ negativno vrednostjo koeficienta asimetričnosti, kar nakazuje na asimetrijo v levo. Vrednosti koeficientov sploščenosti so pri vseh trditvah negativne (preglednica 7), kar pomeni sploščeno porazdelitev teh spremenljivk.

V sklopu dejavnika »Spremembe v okolju« smo ocenjevali tudi na področju $\gg$ Konkurenti $\ll$, in sicer s štirimi trditvami, katerih povprečne vrednosti, standardne odklone ter vrednosti koeficientov asimetrije in sploščenosti prikazujemo $\mathrm{v}$ preglednici 6 . Na podlagi prikazanih vrednosti ugotavljamo, da so anketiranci v povprečju najvišjo oceno $(3,87)$ dodelili trditvi, da v njihovo panogo ves čas vstopajo novi konkurenti, najnižjo povprečno oceno $(2,69)$ pa ima trditev, da se njihov glavni tekmec $\mathrm{v}$ panogi hitreje prilagaja na spremembe kot oni. Relativno visoko oceno so anketiranci v povprečju podali tudi pri drugih trditvah. Standardni odkloni trditev se gibljejo od I,080 do I,476 (preglednica 6).

Vrednosti koeficientov asimetričnosti so pri vseh trditvah pozitivni, kar nakazuje na asimetrijo v desno. Pri prvi trditvi je vrednost koeficienta asimetričnosti relativno blizu o, kar kaže na normalno porazdelitev spremenljivke glede na simetričnost. Grafični prikaz asimetričnosti je v prilogi 4 . 
Preglednica 6: Rezultati ocen za dejavnik »Spremembe v okolju « - področje $»$ Konkurenti $\ll$

\begin{tabular}{lcccc} 
Trditev & $\begin{array}{c}\text { Povprečna } \\
\text { vrednost } \\
(\mathbf{I}-6)\end{array}$ & $\begin{array}{c}\text { Standardni } \\
\text { odklon }\end{array}$ & $\begin{array}{c}\text { Koef. } \\
\text { asimetričnosti }\end{array}$ & $\begin{array}{c}\text { Koef. } \\
\text { sploščenosti }\end{array}$ \\
$\begin{array}{l}\text { V našo panogo ves čas vstopajo novi } \\
\text { konkurenti. }\end{array}$ & 3,87 & 1,476 & 0,026 & $-1,162$ \\
$\begin{array}{l}\text { Konkurenti v naši panogi pogosto } \\
\text { spreminjajo svojo strategijo. }\end{array}$ & 3,46 & 1,208 & 0,371 & $-0,644$ \\
$\begin{array}{l}\text { Tržni deleži med konkurenti v naši panogi } \\
\text { se š̌asom zelo spreminjajo. }\end{array}$ & 3,13 & 1,080 & 0,709 & 0,040 \\
$\begin{array}{l}\text { Naš glavni tekmec v panogi se hitreje } \\
\text { prilagaja na spremembe kot mi. }\end{array}$ & 2,69 & 1,179 & 0,814 & 0,496 \\
\hline \begin{tabular}{l} 
Povprečje konkurenti \\
\hline
\end{tabular} & 3,29 & & & \\
\hline
\end{tabular}

Vrednosti koeficientov asimetričnosti so pri vseh trditvah pozitivni, kar nakazuje na asimetrijo v desno. Pri prvi trditvi je vrednost koeficienta asimetričnosti relativno blizu o, kar kaže na normalno porazdelitev spremenljivke glede na simetričnost. Grafični prikaz asimetričnosti je v prilogi 4 .

Vrednosti koeficientov sploščenosti sta pri prvih dveh trditvah negativni, kar pomeni sploščeno porazdelitev teh spremenljivk, pri zadnji trditvi je vrednost pozitivna, kar kaže na sploščeno porazdelitev te spremenljivke. Pri tretji trditvi je vrednost koeficienta sploščenosti relativno blizu o, kar kaže na normalno porazdelitev spremenljivke glede na njeno sploščenost.

V okviru dejavnika $\gg$ Spremembe v okolju« smo se osredotočili tudi na spremembe na področju »Tehnologija«. Tudi $v$ tem primeru smo uporabili štiri trditve, katerih povprečne vrednosti, standardne odklone ter vrednosti koeficientov asimetrije in sploščenosti prikazujemo v preglednici 7. Na podlagi prikazanih vrednosti ugotavljamo, da so anketiranci v povprečju najvišjo oceno $(4,07)$ dodelili trditvi, da jim tehnološke spremembe omogočajo veliko novih priložnosti za rast njihovega podjetja, najnižjo povprečno oceno $(3,5 \mathrm{I})$ pa ima trditev, da je tehnološki razvoj za nadaljnja 2-3 leta v njihovi panogi zelo težko napovedati. Relativno visoko oceno so anketiranci v povprečju podali tudi pri drugih trditvah. Standardni odkloni trditev se gibljejo od 1,303 do I,4I5 (preglednica 7). 
Preglednica 7: Rezultati ocen za dejavnik »Spremembe v okolju « - področje $\gg$ Tehnologija

\begin{tabular}{lcccc} 
Trditev & $\begin{array}{c}\text { Povprečna } \\
\text { vrednost } \\
(\mathbf{I}-\mathbf{6})\end{array}$ & $\begin{array}{c}\text { Standardni } \\
\text { odklon }\end{array}$ & $\begin{array}{c}\text { Koef. } \\
\text { asimetričnosti }\end{array}$ & $\begin{array}{c}\text { Koef. } \\
\text { sploščenosti }\end{array}$ \\
$\begin{array}{l}\text { Tehnološke spremembe, ki se dogajajo v } \\
\text { naši panogi, so zelo velike. }\end{array}$ & 3,83 & 1,336 & 0,036 & $-0,764$ \\
$\begin{array}{l}\text { Tehnološke spremembe se v naši panogi } \\
\text { dogajajo zelo hitro. }\end{array}$ & 3,66 & 1,415 & 0,074 & $-0,973$ \\
$\begin{array}{l}\text { Tehnološke spremembe nam omogoča- } \\
\text { jo veliko novih priložnosti za rast naše- } \\
\text { ga podjetja. }\end{array}$ & 4,07 & 1,303 & $-0,138$ & $-0,779$ \\
$\begin{array}{l}\text { Tehnološki razvoj za nadaljnja 2-3 leta je v } \\
\text { naši panogi zelo težko napovedati. }\end{array}$ & 3,51 & 1,312 & 0,254 & $-0,612$ \\
\hline \begin{tabular}{l} 
Skupaj tehnologija \\
\hline
\end{tabular} & 3,77 & & & \\
\hline
\end{tabular}

Vrednosti koeficientov asimetričnosti so pri večini trditev pozitivne, kar nakazuje na asimetrijo v desno. Pri prvi trditvi je vrednost koeficienta asimetričnosti relativno blizu o, kar kaže na normalno porazdelitev spremenljivke glede na simetričnost. V primeru tretje trditve ima koeficient asimetričnosti negativno vrednost, kar nakazuje na asimetrijo v levo. Vrednosti koeficientov sploščenosti so pri vseh trditvah negativne, kar pomeni sploščeno porazdelitev teh spremenljivk. Grafični prikaz asimetričnosti je $\mathrm{v}$ prilogi 4 .

Nenazadnje smo se v okviru dejavnika »Spremembe v okolju « osredotočili še na spremembe na področju $\gg$ Dobavitelji«, ki smo jih ocenili s pomočjo štirih trditev. Njihove povprečne vrednosti, standardne odklone ter vrednosti koeficientov asimetrije in sploščenosti prikazujemo v preglednici ı. Na podlagi prikazanih vrednosti ugotavljamo, da so anketiranci v povprečju najvišjo oceno $(4,80)$ dodelili trditvi, da s svojimi glavnimi dobavitelji vzpostavljajo dolgoročna strateška partnerstva, najnižjo povprečno oceno $(3,46)$ pa ima trditev, da je konkurenčnost njihovih izdelkov oz. storitev odvisna predvsem od inovativnosti njihovih dobaviteljev (preglednica 8).

Relativno visoko oceno so anketiranci v povprečju podali tudi pri drugih trditvah. Standardni odkloni trditev se gibljejo od I,I 44 do I,42O. Vrednosti koeficientov asimetričnosti so pri večini trditev negativne, kar nakazuje na asimetrijo v levo. Izjema je le četrta trditev, pri kateri je vrednost koeficienta asimetričnosti pozitivna, kar nakazuje na asimetrijo $\mathrm{v}$ desno. Vrednosti koeficientov sploščenosti sta pri prvih dveh trditvah po- 
zitivni, kar pomeni koničasto porazdelitev teh spremenljivk, pri zadnjih dveh trditvah pa sta vrednosti negativni, kar pomeni sploščeno porazdelitev teh spremenljivk. Grafični prikaz asimetričnosti je v prilogi 4.

Preglednica 8: Rezultati ocen za dejavnik »Spremembe v okolju « - področje »Dobavitelji «

\begin{tabular}{lcccc} 
Trditev & $\begin{array}{c}\text { Povprečna } \\
\text { vrednost } \\
(\mathbf{I}-6)\end{array}$ & $\begin{array}{c}\text { Standardni } \\
\text { odklon }\end{array}$ & $\begin{array}{c}\text { Koef. } \\
\text { asimetričnosti }\end{array}$ & $\begin{array}{c}\text { Koef. } \\
\text { sploščnosti }\end{array}$ \\
$\begin{array}{l}\text { Naši glavni dobavitelji veljajo za vodilne } \\
\text { na svojem področju poslovanja. }\end{array}$ & 4,53 & 1,219 & $-0,686$ & 0,019 \\
$\begin{array}{l}\text { Znašimi glavnimi dobavitelji vzpostavlja- } \\
\text { mo dolgoročna strateška partnerstva. }\end{array}$ & 4,80 & 1,149 & $-0,919$ & 0,504 \\
$\begin{array}{l}\text { Naši glavni dobavitelji se hitro prilagajajo } \\
\text { spremembam v panogi. }\end{array}$ & 4,22 & 1,144 & $-0,268$ & $-0,146$ \\
$\begin{array}{l}\text { Konkurenčnost naših izdelkov/storitev je } \\
\text { odvisna predvsem od inovativnosti naših } \\
\text { dobaviteljev. }\end{array}$ & 3,46 & I, 420 & 0,154 & $-0,764$ \\
\hline
\end{tabular}

Skupaj dobavitelji

4,25

Če povzamemo, so anketiranci v sklopu preverjanj vpliva dejavnika $\gg$ Spremembe $\mathrm{v}$ okolju « na podjetje $\mathrm{v}$ povprečju najvišjo oceno $(4,34)$ dodelili trditvi, da kupci v njihovi panogi nenehno zahtevajo nove izdelke oz. storitve. $Z$ najnižjo povprečno oceno $(3,07)$ so ovrednotili trditev, da se zahteve kupcev o izdelkih oz. storitvah s časom zelo malo spreminjajo. $Z$ vidika konkurentov so anketiranci v povprečju najvišjo oceno $(3,87)$ dodelili trditvi, da v njihovo panogo ves čas vstopajo novi konkurenti, najnižjo povprečno oceno $(2,69)$ pa ima trditev, da se njihov glavni tekmec $\mathrm{v}$ panogi hitreje prilagaja na spremembe kot oni. Na podlagi prikazanih vrednosti prav tako ugotavljamo, da so anketiranci v povprečju najvišjo oceno $(4,07)$ dodelili trditvi, da jim tehnološke spremembe omogočajo veliko novih priložnosti za rast njihovega podjetja, najnižjo povprečno oceno $(3,5 \mathrm{I})$ pa ima trditev, da je tehnološki razvoj za nadaljnja 2-3 leta v njihovi panogi zelo težko napovedati. Glede dobaviteljev so anketiranci v povprečju najvišjo oceno $(4,80)$ dodelili trditvi, da s svojimi glavnimi dobavitelji vzpostavljajo dolgoročna strateška partnerstva.

\section{Rezultati ocen za dejavnik »Strategija podjetja do kupcev《}

V tem poglavju predstavljamo rezultate drugega sklopa anketnega vprašalnika, kjer smo anketirance povprašali po dejavniku »Strategija podjetja do kupcev«, ki v našem modelu povezav (slika I) predstavlja enega izmed dejavnikov, za katerega smo predpostavili, da vpliva na uspešnost 
podjetja. Glede na razviti model smo v dejavnike strategije podjetja do kupcev vključili področja $\gg$ Strategija diferenciacije «, »Strategija nizkih stroškov in privlačnih cen «, »Strategija osredinjenja « ter »Strategija prehitevanja $\ll$. Tudi v tem delu anketnega vprašalnika so anketiranci na izbrane trditve za vsako izmed strategij odgovarjali s pomočjo šeststopenjske lestvice, $s$ katero so ocenili, koliko velja za primer njihovega podjetja. Pri tem je ocena I pomenila, da trditev za podjetje nikakor ne drži, ocena $6 \mathrm{pa}$, da trditev za podjetje zelo drži. Skupno povprečje posameznih trditev smo izračunali tako, da smo sešteli povprečne vrednosti posameznih trditev in vsoto delili s številom trditev. Za vsako izmed trditev smo izračunali povprečja, standardne odklone ter vrednosti koeficientov asimetrije in sploščenosti, kar je predstavljeno $\mathrm{v}$ preglednicah $\mathrm{v}$ nadaljevanju tega poglavja in prilogah (priloga 4).

V okviru preučevanja strategije diferenciacije smo uporabili štiri trditve, katerih povprečja, standardne odklone ter vrednosti koeficientov asimetrije in sploščenosti prikazujemo v preglednici 9 . Na podlagi prikazanih vrednosti ugotavljamo, da so anketiranci v povprečju najvišjo oceno $(4,83)$ dodelili trditvi, da stremijo k prepoznavnosti lastne blagovne znamke, najnižjo povprečno oceno $(2,98)$ pa ima trditev, da so njihovi izdelki oz. storitve bistveno drugačni od njihovega glavnega tekmeca v panogi. Relativno visoko oceno so anketiranci v povprečju podali tudi pri drugih trditvah. Standardni odkloni trditev se gibljejo od 1,232 do 1,366 (preglednica 9).

Vrednosti koeficientov asimetričnosti sta pri prvi in četrti trditvi pozitivni, kar nakazuje na asimetrijo v desno. Pri tretji trditvi je vrednost negativna, kar pomeni asimetrijo v levo. Grafični prikaz asimetričnosti je v prilogi 4 .

Preglednica 9: Rezultati ocen za dejavnik »Strategija podjetja do kupcev« - področje

$»$ Strategija diferenciacije $\ll$

\begin{tabular}{lcccc} 
Trditev & $\begin{array}{c}\text { Povprečna } \\
\text { vrednost } \\
(\mathbf{I}-6)\end{array}$ & $\begin{array}{c}\text { Standardni } \\
\text { odklon }\end{array}$ & $\begin{array}{c}\text { Koef. } \\
\text { asimetričnosti }\end{array}$ & $\begin{array}{c}\text { Koef. } \\
\text { sploščnosti }\end{array}$ \\
$\begin{array}{l}\text { Naši izdelki/storitve so bistveno drugačni } \\
\text { od našega glavnega tekmeca v panogi. }\end{array}$ & 2,98 & $\mathrm{I}, 232$ & 0,468 & $-0,168$ \\
$\begin{array}{l}\text { Pri trženju smo inovativnejši kot naš } \\
\text { glavni tekmec v panogi. }\end{array}$ & 3,78 & 1,242 & $-0,002$ & $-0,755$ \\
$\begin{array}{l}\text { Stremimo k prepoznavnosti lastne bla- } \\
\text { govne znamke. }\end{array}$ & 4,83 & 1,253 & $-0,939$ & 0,112 \\
$\begin{array}{l}\text { Več vlagamo v marketinško komuniciran- } \\
\text { je kot naš glavni tekmec v panogi. }\end{array}$ & 3,44 & 1,366 & 0,071 & $-0,68 \mathrm{I}$ \\
\hline \begin{tabular}{l} 
Skupaj strategija diferenciacije \\
\hline
\end{tabular} & 3,76 & & & \\
\hline
\end{tabular}


$\mathrm{V}$ primeru druge trditve je vrednost koeficienta asimetričnosti skoraj o, kar nakazuje na simetrično porazdelitev. Vrednosti koeficientov sploščenosti so pri večini trditev negativne, kar pomeni sploščeno porazdelitev. Izjema je le tretja trditev, za katero pozitivna vrednost koeficienta sploščenosti nakazuje na njeno koničasto porazdelitev.

V sklopu dejavnika »Strategija podjetja do kupcev« so anketiranci ocenili tudi področje »Strategija nizkih stroškov in privlačnih cen «, in sicer $s$ štirimi trditvami, katerih povprečne vrednosti, standardne odklone ter vrednosti koeficientov asimetrije in sploščenosti prikazujemo v preglednici i 2. Na podlagi prikazanih vrednosti ugotavljamo, da so anketiranci v povprečju najvišjo oceno $(4,23)$ dodelili trditvi, da so v podjetju pri izvajanju poslovnih aktivnosti visoko učinkoviti (produktivni), najnižjo povprečno oceno (3, I I) pa ima trditev, da na trgu konkurirajo z nizkimi cenami svojih storitev oz. izdelkov. Relativno visoko oceno so anketiranci v povprečju podali tudi pri drugih trditvah. Standardni odkloni trditev se gibljejo od I,08 I do I,257. Vrednosti koeficientov asimetričnosti so pri večini trditev negativni, kar nakazuje na asimetrijo v levo. Izjema je le druga trditev, katere pozitivna vrednost koeficienta asimetričnosti nakazuje na asimetrijo v desno. Vrednosti koeficientov sploščenosti so pri vseh trditvah negativne, kar pomeni sploščeno porazdelitev (preglednica Io).

Preglednica ı: Rezultati ocen za dejavnik »Strategija podjetja do kupcev« - področje »Strategija nizkih stroškov in privlačnih cen«

\begin{tabular}{lcccc} 
Trditev & $\begin{array}{c}\text { Povprečna } \\
\text { vrednost } \\
(\mathbf{I}-6)\end{array}$ & $\begin{array}{c}\text { Standardni } \\
\text { odklon }\end{array}$ & $\begin{array}{c}\text { Koef. } \\
\text { asimetričnosti }\end{array}$ & $\begin{array}{c}\text { Koef. } \\
\text { sploščnosti }\end{array}$ \\
$\begin{array}{l}\text { V podjetju smo pri izvajanju poslovnih } \\
\text { aktivnosti visoko učinkoviti (produk- } \\
\text { tivni). }\end{array}$ & 4,23 & 1,174 & $-0,464$ & $-0,197$ \\
$\begin{array}{l}\text { Na trgu konkuriramo z nizkimi cenami } \\
\text { svojih izdelkov/storitev. }\end{array}$ & 3,11 & 1,257 & 0,487 & $-0,248$ \\
$\begin{array}{l}\text { V procesih podjetja nenchno poudarja- } \\
\text { mo zniževanje vseh vrst stroškov poslo- } \\
\text { vanja. }\end{array}$ & 4,04 & 1,242 & $-0,188$ & $-0,555$ \\
$\begin{array}{l}\text { Pri iskanju stroškovno najugodnejših vi- } \\
\text { rov (materialov, energije, znanja ipd.) na } \\
\text { trgu smo zelo uspešni. }\end{array}$ & 3,85 & & & \\
\hline $\begin{array}{l}\text { Skupaj strategija nizkih stroškov in } \\
\text { privlačnih cen }\end{array}$ & $3,8 \mathrm{I}$ & & $-0,0,165$ & $-0,117$ \\
\hline
\end{tabular}

V okviru preučevanja dejavnika »Strategija podjetja do kupcev《smo se osredotočili tudi na področje »Strategija osredinjenja《. Tudi v tem 
primeru smo uporabili štiri trditve, katerih povprečne vrednosti, standardne odklone ter vrednosti koeficientov asimetrije in sploščenosti prikazujemo v preglednici i I.

Preglednica I I: Rezultati ocen za dejavnik »Strategija podjetja do kupcev« - področje » Strategija osredinjenja $\ll$

\begin{tabular}{|c|c|c|c|c|}
\hline Trditev & $\begin{array}{c}\text { Povprečna } \\
\text { vrednost } \\
(1-6)\end{array}$ & $\begin{array}{l}\text { Standardni } \\
\text { odklon }\end{array}$ & $\begin{array}{l}\text { Koef. asi- } \\
\text { metričnosti }\end{array}$ & $\begin{array}{c}\text { Koef. } \\
\text { sploščenosti }\end{array}$ \\
\hline $\begin{array}{l}\text { Z našimi izdelki/storitvami ciljamo na } \\
\text { ozek segment kupcev. }\end{array}$ & 3,12 & 1,613 & 0,307 & $-1,073$ \\
\hline $\begin{array}{l}\text { Na trg ponujamo ožji nabor izdelkov/ } \\
\text { storitev kot naša konkurenca. }\end{array}$ & 2,62 & 1,419 & 0,698 & $-0,44^{8}$ \\
\hline $\begin{array}{l}\text { Na trg ponujamo izdelke/storitve v oz- } \\
\text { kem cenovnem segmentu. }\end{array}$ & 2,67 & 1,212 & 0,598 & $-0, \mathrm{I} 4 \mathrm{I}$ \\
\hline $\begin{array}{l}\text { Na trg ponujamo specialne/nišne izdel- } \\
\text { ke/storitve. }\end{array}$ & 3,84 & 1,559 & $-0,245$ & $-1,077$ \\
\hline Skupaj strategija osredinjenja & 3,06 & & & \\
\hline
\end{tabular}

$\mathrm{Na}$ podlagi prikazanih vrednosti ugotavljamo, da so anketiranci $\mathrm{v}$ povprečju najvišjo oceno $(3,84)$ dodelili trditvi, da na trg ponujajo specialne oz. nišne izdelke oz. storitve, z najnižjo povprečno oceno $(3,62)$ so ocenili trditev, da na trg ponujajo ožji nabor izdelkov oz. storitev kot njihova konkurenca. Relativno nizko oceno so anketiranci v povprečju podali tudi pri drugih trditvah. Standardni odkloni trditev se gibljejo od I,2 I 2 do I,6I3. Vrednosti koeficientov asimetričnosti so pri večini trditev pozitivne, kar nakazuje na asimetrijo v desno. Izjema je le zadnja trditev, pri kateri je vrednost koeficienta asimetričnosti negativna, kar kaže na asimetrijo v levo. Vrednosti koeficientov sploščenosti so pri vseh trditvah negativne, kar pomeni sploščeno porazdelitev. Grafični prikaz asimetričnosti je v prilogi 4.

Nenazadnje smo se v okviru preučevanja dejavnika »Strategija podjetja do kupcev《 osredotočili še na področje »Strategija prehitevanja «, ki smo ga ocenili s pomočjo štirih trditev. Njihove povprečne vrednosti, standardne odklone ter vrednosti koeficientov asimetrije in sploščenosti prikazujemo v preglednici $\mathbf{2}$.

$\mathrm{Na}$ podlagi prikazanih vrednosti ugotavljamo, da so anketiranci v povprečju najvišjo oceno $(3,79)$ dodelili trditvama, da so pri uvajanju sprememb v svoje poslovanje hitrejši kot njihov glavni tekmec in da spremembe v panogi sprožajo hitreje kot njihovi tekmeci. Najnižjo povprečno oceno $(3,75)$ so dodelili trditvi, da nove potrebe trga zaznajo hitreje 
kot njihov glavni tekmec. Relativno visoko oceno $(3,77)$ so anketiranci v povprečju podali tudi pri trditvi, da nove izdelke oz. storitve na trg uvajajo hitreje kot njihov glavni tekmec. Standardni odkloni trditev se gibljejo od I,202 do I,299.

Preglednica I2: Rezultati ocen za dejavnik »Strategija podjetja do kupcev« - področje »Strategija prehitevanja

\begin{tabular}{lcccc} 
Trditev & $\begin{array}{c}\text { Povprečna } \\
\text { vrednost } \\
(\mathbf{1}-6)\end{array}$ & $\begin{array}{c}\text { Standardni } \\
\text { odklon }\end{array}$ & $\begin{array}{c}\text { Koef. asi- } \\
\text { metričnosti }\end{array}$ & $\begin{array}{c}\text { Kocf. } \\
\text { sploščnosti }\end{array}$ \\
$\begin{array}{l}\text { Nove potrebe trga zaznamo hitreje kot } \\
\text { naš glavni tekmec. }\end{array}$ & 3,75 & 1,202 & 0,032 & $-0,446$ \\
$\begin{array}{l}\text { Nove izdelke/storitve na trg uvajamo hi- } \\
\text { treje kot naš glavni tekmec. }\end{array}$ & 3,77 & 1,239 & $-0,151$ & $-0,526$ \\
$\begin{array}{l}\text { Pri uvajanju sprememb v naše poslovanje } \\
\text { smo hitrejsis kot naš glavni tekmec. }\end{array}$ & 3,79 & 1,241 & $-0,133$ & $-0,570$ \\
$\begin{array}{l}\text { Spremembe v panogi sprožzamo hitreje } \\
\text { kot naš glavni tekmec. }\end{array}$ & 3,79 & 1,299 & $-0,072$ & $-0,648$ \\
\hline Skupaj strategija prehitevanja & 3,78 & & & \\
\hline
\end{tabular}

Vrednosti koeficientov asimetričnosti so pri večini trditev negativne, kar nakazuje na asimetrijo v levo. Izjema je le prva trditev, pri kateri je vrednost koeficienta asimetričnosti pozitivna, kar nakazuje na asimetrijo v desno. Vrednosti koeficientov sploščenosti so pri vseh trditvah negativne, kar pomeni sploščeno porazdelitev. Grafični prikaz asimetričnosti je v prilogi 4.

Če povzamemo, so anketiranci za dejavnik »Strategija podjetja do kupcev« v povprečju najvišjo oceno $(4,83)$ dodelili trditvi, da stremijo $\mathrm{k}$ prepoznavnosti lastne blagovne znamke. Prav tako so ocenili stanje uporabe strategije nizkih stroškov in privlačnih cen, kjer so v povprečju $\mathrm{z}$ najvišjo oceno $(4,23)$ ocenili trditev, da so v podjetju pri izvajanju poslovnih aktivnosti visoko učinkoviti (produktivni). Pri uporabi strategije diferenciacije so najvišjo oceno $(3,84)$ dodelili trditvi, da na trg ponujajo specialne oz. nišne izdelke oz. storitve, $\mathrm{z}$ najnižjo povprečno oceno $(3,62)$ pa so ocenili trditev, da na trg ponujajo ožji izbor izdelkov oz. storitev kot njihova konkurenca. $V$ povprečju so pri strategiji prehitevanja najvišjo oceno $(3,79)$ dodelili trditvama, da so pri uvajanju sprememb $\mathrm{v}$ svoje poslovanje hitrejši kot njihov glavni tekmec in da spremembe $\mathrm{v}$ panogi sprožajo hitreje kot njihovi tekmeci. Najnižjo povprečno oceno $(3,75)$ so dodelili trditvi, da nove potrebe trga zaznajo hitreje kot njihov glavni tekmec. Relativno visoko oceno $(3,77)$ so anketiranci v povprečju 
podali tudi pri trditvi, da nove izdelke oz. storitve na trg uvajajo hitreje kot njihov glavni tekmec.

\section{Rezultati ocen o uspešnosti anketiranib podjetij}

V zadnjem delu empiričnega dela prehajamo na rezultate analize podatkov iz vprašalnika, ki se je nanašal na uspešnost podjetij. Uspešnost podjetij v našem modelu povezav (slika I) predstavlja odvisno spremenljivko. Kot je razvidno iz predhodnih poglavij, smo predpostavili, da na uspešnost podjetij vplivajo (I) dejavnik »Spremembe okolja podjetja «, ka-

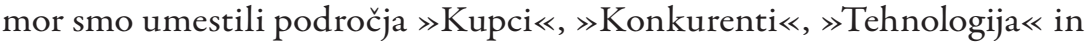
»Dobavitelji«; (2) dejavnik »Strategija podjetja do kupcev«, kamor smo umestili področja »Strategija diferenciacije «, »Strategija nizki stroški in privlačne cene «, »Strategija osredinjenja « ter »Strategija prehitevanja $\ll$. Preverili smo, kakšen vpliv ima posamezen dejavnik na uspešnost podjetja. Uspešnost smo v našem primeru merili na kompleksen način, kot so nam narekovala spoznanja v teoretičnem delu raziskave. Podatke o uspešnosti podjetij smo pridobili iz sekundarnih virov (GVIN). Zajeli smo časovno obdobje za tista leta, za katera so bili podatki na voljo v javno dostopnih bazah (GVIN), in sicer za: finančno uspešnost podjetij (ROA, $\mathrm{ROE}$ ), operativno uspešnost podjetij (EVA) in bonitetno oceno podjetij (BON). Dodatno so anketiranci uspešnost svojega podjetja sami ocenili relativno glede na njihovega glavnega tekmeca v panogi in s pomočjo šeststopenjske lestvice (priloga I).

Iz preglednice 24 je razvidno, da največ anketirancev $(35,0 \%)$ uspešnost podjetja glede na glavnega tekmeca v panogi ocenjuje (presoja) z oceno 4 , najmanj anketirancev ( $1,8 \%$ ) pa z oceno $\mathrm{I}$, torej kot bistveno manj uspešno v primerjavi z njihovim glavnim tekmecem (preglednica I3).

Preglednica I3: Uspešnost podjetja glede na glavnega tekmeca v panogi

\begin{tabular}{lcc} 
Uspešnost podjetja glede na glavnega tekmeca v panogi & Frekvenca & Delež $(\%)$ \\
\hline I- Bistveno manj uspešno kot naš glavni tekmec & 3 & 1,8 \\
2-Manj uspešno kot naš glavni tekmec & 7 & 4,3 \\
3-Malo manj uspešno kot naš glavni tekmec & 21 & 12,9 \\
4- Malo uspešnejše kot naš glavni tekmec & 57 & 35,0 \\
5- Uspešnejše kot naš glavni tekmec & 42 & 25,8 \\
6- Bistveno uspešnejše kot naš glavni tekmec & 33 & 20,2 \\
\hline Skupaj & 163 & 100,0 \\
\hline
\end{tabular}


Povprečje, standardni odklon ter vrednosti koeficienta asimetrije in sploščenosti za odvisno spremenljivko uspešnosti podjetja glede na glavnega tekmeca v panogi prikazujemo v preglednici $\mathbf{4} 4$.

Preglednica I4: Izid ocene uspešnosti podjetja glede na glavnega tekmeca v panogi

\begin{tabular}{lcccc} 
& $\begin{array}{c}\text { Povprečna } \\
\text { vrednost } \\
(\mathbf{I}-6)\end{array}$ & $\begin{array}{c}\text { Standardni } \\
\text { odklon }\end{array}$ & $\begin{array}{c}\text { Koef. } \\
\text { asimetričnosti }\end{array}$ & $\begin{array}{c}\text { Koef. } \\
\text { sploščenosti }\end{array}$ \\
\hline $\begin{array}{l}\text { Uspešnost podjetja glede na glavnega tek- } \\
\text { meca v panogi }\end{array}$ & 4,39 & 1,178 & $-0,484$ & 0,046 \\
\hline
\end{tabular}

$\mathrm{V}$ povprečju so anketiranci uspešnost svojega podjetja glede na glavnega tekmeca $v$ panogi ocenili z oceno 4,39, s standardnim odklonom I,I78. Glede na negativno vrednost koeficienta asimetričnosti se kaže asimetrija v levo. Vrednost koeficienta sploščenosti je pozitivna in relativno blizu o, kar pomeni rahlo koničasto porazdelitev. Grafični prikaz asimetričnosti je v prilogi 4. Podroben pregled zbranih podatkov o uspešnosti podjetij (ROA, ROE, EVA, BON) na podlagi javno dostopne baze GVIN je v prilogi 4 .

\section{Preverjanje teoretičnega modela za dejavnik »Spremembe v okolju«}

Glede na naš razviti model povezav (Slika r) smo za dejavnik »Spremembe v okolju «, ki zajema področja $\gg$ Kupci $\ll, ~ \gg K o n k u r e n t i \ll, ~ \gg T e h n o l o g i-$ ja $\ll$ in $\gg$ Dobavitelji $\ll$, najprej preverili, ali so posamezne trditve znotraj vsakega vidika dovolj povezane, da bi bila faktorska analiza v nadaljevanju smiselna. Preverili smo še interno konsistentnost (zanesljivost oz. ponovljivost) rezultatov ob podobnih podatkih, ki jo merimo s parametrom

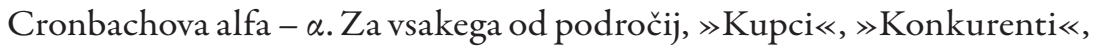
$\gg$ Tehnologija $\ll$ in $\gg$ Dobavitelji«, predstavljamo rezultate analize v obliki preglednic in komentarjev.

Sledi predstavitev rezultatov analize dejavnika »Spremembe v oko-

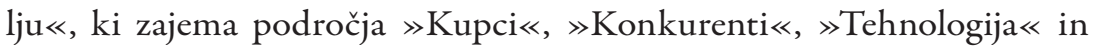
$\gg$ Dobavitelji«(slika I).

\section{Rezultati ocen na področju $\gg$ Kupci«}

Kupci v našem modelu povezav predstavljajo sestavni del dejavnika »Spremembe v okolju«, za katerega smo na podlagi raziskane literature in spoznanj v teoretičnem delu predpostavili, da ima vpliv na odvisno spremenljivko, to je »Strategija podjetja do kupcev«(slika I). Uvodoma 
predstavljamo rezultate analize povezanosti posameznih trditev in rezultate analize interne konsistentnosti, ki se nanašajo na kupce.

Vrednosti v preglednicah v nadaljevanju prikazujejo povezanost in moč povezave med posameznimi trditvami ter smer povezave. Višja je vrednost pri posamezni trditvi, močnejša je povezava. Pozitivne vrednosti kažejo povezanost v enaki smeri (bolj ko drži posamezna trditev, bolj drži z njo povezana trditev), negativne vrednosti kažejo povezanost v obratni smeri (bolj ko drži posamezna trditev, manj drži z njo povezana trditev). Yong in Pearce $(2013,79-94)$ predlagata, da trditve, pri katerih zaznamo povezanost pod o,3, izločimo (odstranimo) iz nadaljnje analize. V naših primerih smo za izločitev (odstranitev) upoštevali tudi druge kriterije (povezanost med trditvami glede na vrednosti, ponavljanje vrednosti pod o,3 pri enaki trditvi, zanesljivost koeficienta Cronbachova alfa). Najprej smo preverili povezanost med trditvami znotraj področja $\gg$ Kupci«. Preverili smo, ali so posamezne trditve dovolj povezane, da bi bila faktorska analiza v nadaljevanju smiselna. Preglednica is kaže rezultate analize.

Preglednica i s: Področje $»$ Kupci $\ll-$ povezanost med trditvami

\begin{tabular}{|c|c|c|c|c|}
\hline Trditev & $\begin{array}{c}\text { Kupci v naši } \\
\text { panogi neneh- } \\
\text { no zahtevajo } \\
\text { nove izdelke/ } \\
\text { storitve. }\end{array}$ & $\begin{array}{l}\text { Zahteve kup- } \\
\text { cev o izdel- } \\
\text { kih/storit- } \\
\text { vah se s časom } \\
\text { zelo malo } \\
\text { spreminjajo. }\end{array}$ & $\begin{array}{l}\text { Na nas se } \\
\text { obračajo } \\
\text { povsem novi } \\
\text { kupci, s kate- } \\
\text { rimi še nismo } \\
\text { sodelovali. }\end{array}$ & $\begin{array}{l}\text { Struktura naših } \\
\text { kupcev se s ča- } \\
\text { som zelo malo } \\
\text { spreminja. }\end{array}$ \\
\hline $\begin{array}{l}\text { Kupci v naši panogi nenehno zahtevajo } \\
\text { nove izdelke/storitve. }\end{array}$ & 1,000 & & & \\
\hline $\begin{array}{l}\text { Zahteve kupcev o izdelkih/storitvah se s } \\
\text { časom zelo malo spreminjajo. }\end{array}$ & $-0,261$ & 1,000 & & \\
\hline $\begin{array}{l}\text { Na nas se obračajo povsem novi kupci, s } \\
\text { katerimi še nismo sodelovali. }\end{array}$ & 0,255 & $-0,020$ & 1,000 & \\
\hline $\begin{array}{l}\text { Struktura naših kupcev se s časom zelo } \\
\text { malo spreminja. }\end{array}$ & 0,044 & 0,301 & $-0,046$ & I,, 000 \\
\hline
\end{tabular}

Determinanta $=0,772$

Rezultati kažejo, da obstaja več trditev znotraj področja »Kupci«, ki so med seboj slabo povezane. To nakazujejo vrednosti pod o,3. Po drugi strani je treba biti previden zaradi problema multikolinearnosti v podatkih (torej redundanco, da $\mathrm{z}$ dvema trditvama ne bi merili enega in istega). Na zadnje nas opozori vrednost determinante, za katero si želimo, da je nad o,०००or. V našem primeru je determinanta za področje »Kup- 
ci $<, 772$, kar pomeni, da so naše trditve ustrezne in primerne za nadaljnjo analizo.

Preverili smo še interno konsistentnost (zanesljivost oz. ponovljivost) rezultatov ob podobnih podatkih, ki jo merimo s parametrom Cronbachova alfa $-\alpha$ (priloga 6). Parameter Cronbachova alfa za področje $\gg$ Kupci« znaša o, I 48, kar je po Tavakolu in Dennicku (20I I, 53) manj kot o,5 in pomeni, da je naš sklop trditev za področje »Kupci« premalo konsistenten. Tudi z izločevanjem posameznih trditev tega v našem primeru ne moremo izboljšati. Za področje »Kupci« torej ne moremo govoriti o enodimenzionalnosti področja, ampak bomo skozi analizo posamezne trditve na področju $\gg$ Kupci« obravnavali ločeno.

\section{Rezultati ocen na področju »Konkurentik}

64 Konkurenti v našem modelu povezav predstavljajo sestavni del dejavnika $\gg$ Spremembe v okolju« , za katerega smo na podlagi raziskane literature in spoznanj v teoretičnem delu predpostavili, da ima vpliv na odvisno spremenljivko, to je strategijo podjetja do kupcev (slika I). Uvodoma predstavljamo rezultate analize povezanosti posameznih trditev in rezultate analize interne konsistentnosti, ki se nanašajo na področje »Konkurenti《.

$\mathrm{V}$ našem primeru so vse trditve znotraj področja $\gg$ Konkurenti $\ll$, razen pri trditvi $\gg \mathrm{Naš} \mathrm{glavni} \mathrm{tekmec} \mathrm{v}$ panogi se hitreje prilagaja na spremembe kot mi $\ll$, dovolj povezane. To nakazujejo vrednosti pod o,3 (preglednica 16).

Preglednica 16: Področje »Konkurenti « - povezanost med trditvami

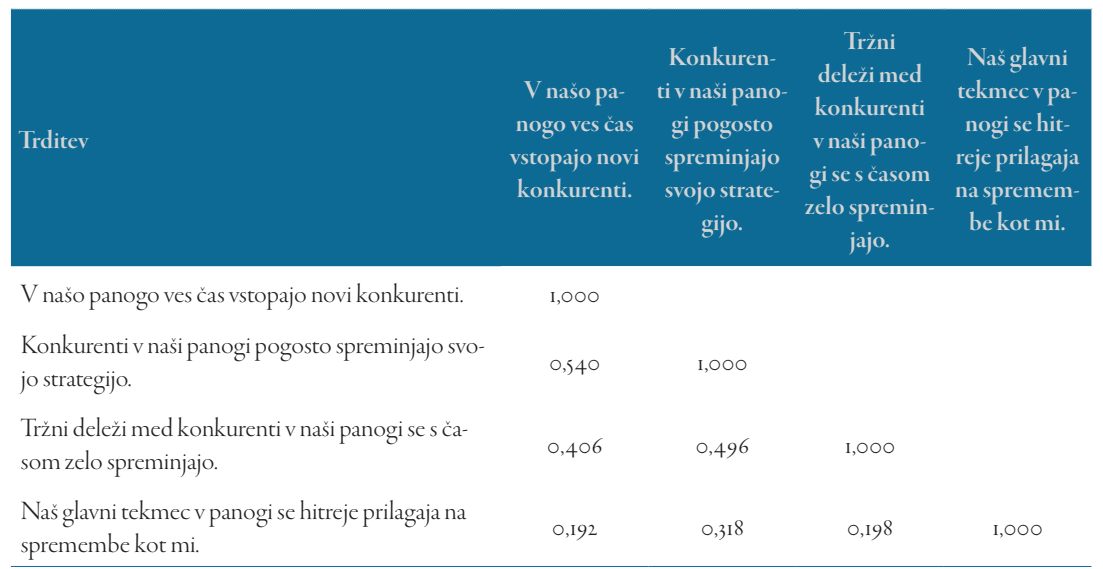

Determinanta $=0,46 \mathrm{I}$ 
$\mathrm{V}$ naslednjem koraku omenjeno trditev izločimo. KMO in Bartlettov test sta nam za področje $\gg$ Konkurenti $<$ pomagala določiti, ali so trditve znotraj področja »Konkurenti《 medsebojno dovolj povezane, da bi bila faktorska analiza $v$ nadaljevanju smiselna. Priporočena vrednost za KMO je nad o,5, pri Bartlettovem testu želimo, da je ta statistično značilen (Yong in Pearce 2013, 79-94). Rezultate prikazuje preglednica 17.

Preglednica 17: Področje »Konkurenti « $-\mathrm{KMO}$ in Bartlettov test

\begin{tabular}{lcc} 
Kaiser-Meyer-Olkinova mera vzorčne ustreznosti & & 0,669 \\
\hline Bartlettov test sferičnosti & Hi-kvadrat & 106,377 \\
& Stopinje prostosti & 3 \\
& p-vrednost & 0,000 \\
\hline
\end{tabular}

Za naš primer rezultati kažejo, da je KMO o,669, kar je nad o,5, prav tako je Bartlettov test statistično značilen, saj je p-vrednost pod o,os (pod $5 \%$ ). Iz tega sklenemo, da so trditve znotraj področja »Konkurenti medsebojno dovolj povezane in da je faktorska analiza v nadaljevanju smiselna.

Analizirali smo tudi komunalitete. Te prikazujejo delež variance opazovanih trditev, ki jo lahko pripišemo skupnemu faktorju »Konkurenti« oz. pojasnjeni varianci (preglednica I8).

Preglednica ı 8: Področje » Konkurenti « - komunalitete

\begin{tabular}{lcc} 
Trditev & Začetni & $\begin{array}{c}\text { Po izločitvi } \\
\text { faktorjev }\end{array}$ \\
\hline V našo panogo ves čas vstopajo novi konkurenti. & 0,317 & 0,444 \\
Konkurenti v naši panogi pogosto spreminjajo svojo strategijo. & 0,384 & 0,657 \\
Tržni deleži med konkurenti v naši panogi se s časom zelo spreminjajo. & 0,273 & 0,374 \\
\hline
\end{tabular}

Preglednica komunalitet (preglednica 29 in podobne preglednice $\mathrm{v}$ nadaljevanju) kaže tiste trditve, ki jih v analizi izpustimo. Začetna komunaliteta vedno kaže stanje pred faktorsko analizo. Podatek o komunaliteti po izločitvi kaže komunaliteto po tem, ko smo združili trditve v en sam faktor. Child (2006) predlaga, da trditve z nizkimi komunalitetami izločimo (odstranimo) iz nadaljnje analize. Pri tem kot mejno vrednost upoštevamo vrednosti pod 0,3 .

Preglednica 19 kaže, da komunalitete pred izločitvijo (ekstrakcijo združivijo v en faktor) niso vse višje kot 0,3 , ampak se zaradi drugih kriterijev (povezanost med trditvami glede na vrednosti, ponavljanje vrednosti 
pod 0,3 pri enaki trditvi, zanesljivost koeficienta Cronbachova alfa) odločimo za ohranitev vseh treh trditev v modelu za namen nadaljnje analize.

Preglednica 19 prikazuje delež celotne pojasnjene variance za področje $\gg$ Konkurenti $\ll$.

Preglednica 19: Področje »Konkurenti « - celotna pojasnjena varianca

\begin{tabular}{|c|c|c|c|c|c|c|}
\hline \multirow{2}{*}{ Faktor } & \multicolumn{3}{|c|}{ Začetne lastne vrednosti } & \multicolumn{3}{|c|}{$\begin{array}{l}\text { Vsota kvadriranih uteži po izločitvi } \\
\text { (po združitvi v en faktor) }\end{array}$} \\
\hline & Skupaj & $\%$ variance & $\begin{array}{c}\text { Kumulativa } \\
\mathbf{v} \%\end{array}$ & Skupaj & $\%$ variance & $\begin{array}{c}\text { Kumulativa } \\
\text { v } \%\end{array}$ \\
\hline I & 1,964 & 65,463 & 65,463 & $\mathrm{I}, 474$ & 49,145 & 49,145 \\
\hline 2 & 0,597 & 19,14 & 85,377 & & & \\
\hline 3 & 0,439 & 14,623 & 100,000 & & & \\
\hline
\end{tabular}

Lastna vrednost nad I nam nakazuje odločitev za izločitev tega, v našem primeru prvega, faktorja. Odločimo se, da obdržimo tisti faktor, kjer je vrednost najvišja. S tem (enim) faktorjem (ki ga upoštevamo v nadaljnji analizi) pojasnimo 49, I \% variance. Višja je ta vrednost, več informacij v naši nadaljnji raziskavi ohranimo.

Tudi glede na kolenski diagram za faktor »Konkurenti« (priloga 4) vidimo, da lahko izločimo optimalno en faktor, kar pomeni, da vse faktorje združimo v en skupni faktor. Uporabili smo Kaiserjev kriterij, ki pravi, da lahko optimalno izločimo toliko faktorjev, kot jih ima lastno vrednost nad I (Kaiser 1960, I4I-I5I). Če povzamemo, podatki (kolenski diagrami, lastne vrednosti, delež variance) potrjujejo enodimenzionalno strukturo področja »Konkurenti《, kar pomeni, da lahko v tem primeru vse trditve izločimo (združimo) v en faktor.

Matrika faktorskih uteži za področje »Konkurenti《kaže, v kolikšni meri posamezna trditev znotraj področja $\gg$ Konkurenti《 prispeva k skupnemu vplivu. Največji vpliv ima zgoraj napisana trditev, »Konkurenti v naši panogi pogosto spreminjajo svojo strategijo « (preglednica 20).

Preglednica 2o: Področje »Konkurenti « - matrika faktorskih uteži

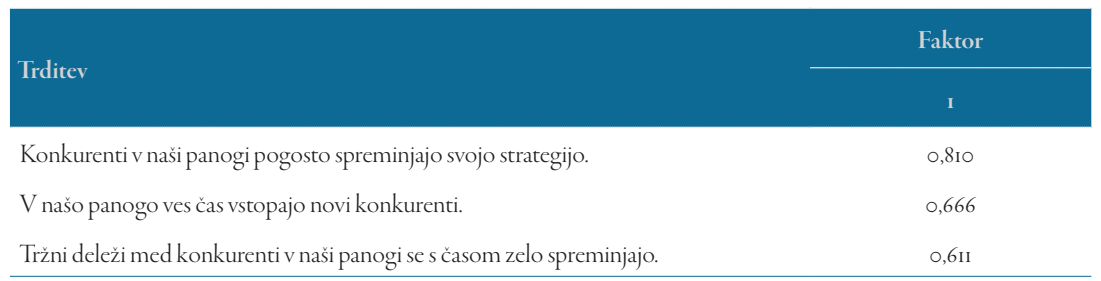


Faktor I v preglednici 3i pomeni, da smo po faktorski analizi vse faktorje izločili (združili, naredili ekstrakcijo) v en skupni faktor. Interna konsistentnost (Cronbachova alfa $-\alpha$ ) prikazuje konsistentnost (zanesljivost oz. ponovljivost rezultatov ob podobnih podatkih) za področje »Konkurenti «. Parameter Cronbachova alfa je 0,727 , kar po Tavakolu in Dennicku (20I I, 53) pomeni, da je naš sklop trditev na področju »Konkurenti $\ll$ dovolj konsistenten (priloga 6).

\section{Rezultati ocen na področju $\gg$ Tehnologija «}

Tehnologija $\mathrm{v}$ našem modelu povezav predstavlja sestavni del dejavnika »Spremembe v okolju«, za katerega smo na podlagi raziskane literature in spoznanj $\mathrm{v}$ teoretičnem delu predpostavili, da ima vpliv na odvisno spremenljivko, to je strategijo podjetja do kupcev (slika I). Uvodoma predstavljamo rezultate analize povezanosti posameznih trditev in rezultate analize interne konsistentnosti, ki se nanašajo na področje »Tehnologija «. V našem primeru so vse trditve, razen »Tehnološki razvoj za nadaljnja 2-3 leta je v naši panogi zelo težko napovedati«, dovolj povezane. Šibko povezavo nakazuje vrednost pod o,3 (Yong in Pearce 2013, 79-94) (preglednica 2r).

Preglednica 21: Področje »Tehnologija «- povezanost med trditvami

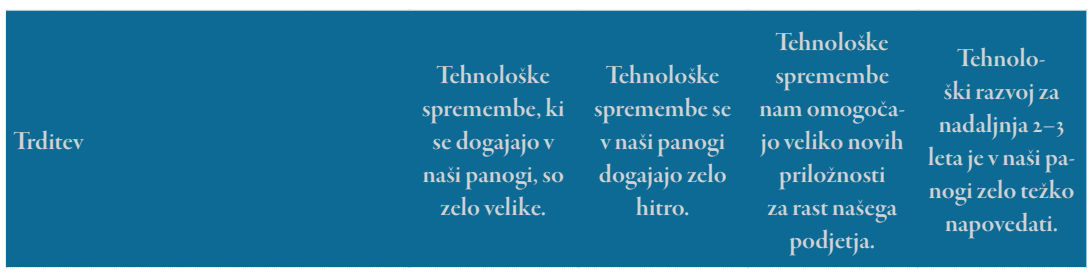

Tehnološke spremembe, ki se dogajajo v naši panogi, so zelo velike.

$\mathrm{I}, \mathrm{OOO}$

Tehnološke spremembe se v naši panogi

dogajajo zelo hitro.

0,838

1,000

Tehnološke spremembe nam omogoča-

jo veliko novih priložnosti za rast naše-

0,553

0,552

$\mathrm{I}, \mathrm{O} 0 \mathrm{O}$

ga podjetja.

Tehnološki razvoj za nadaljnja 2-3 leta je v

naši panogi zelo težko napovedati.

O,I9I

0,193

0,130

1,000

Determinanta $=0,19 \mathrm{I}$

V našem primeru je determinanta 0,I9I, kar je po Yongu in Pearceu (2013, 79-94) nad 0,0000I in pomeni, da različne trditve znotraj področ- 
ja $\gg$ Tehnologija $\ll$ dejansko merijo različen vpliv in so primerne za nadaljnjo analizo.

V naslednjem koraku omenjeno trditev izločimo (odstranimo) s področja $\gg$ Tehnologija «. KMO in Bartlettov test sta nam za področje »Tehnologija « pomagala določiti, ali so trditve znotraj področja medsebojno dovolj povezane, da bi bila faktorska analiza v nadaljevanju smiselna (preglednica 22).

\section{Preglednica 22: Področje »Tehnologija « - KMO in Bartlettov test}

\begin{tabular}{lcc} 
Kaiser-Meyer-Olkinova mera vzorčne ustreznosti & & 0,664 \\
\hline Bartlettov test fferičnosti & Hi-kvadrat & 258,427 \\
& Stopinje prostosti & 3 \\
& p-vrednost & 0,000 \\
\hline
\end{tabular}

Za naš primer rezultati kažejo, da je $\mathrm{KMO}$ o,664, kar je nad o,5, prav tako je Bartlettov test statistično značilen, saj je p-vrednost pod o,05 (pod $5 \%)$. Iz tega sklenemo, da so trditve znotraj področja $\gg$ Tehnologija « medsebojno dovolj povezane in da je faktorska analiza v nadaljevanju smiselna.

Analizirali smo tudi komunalitete za področje »Tehnologija«. Te prikazujejo delež variance opazovanih trditev, ki jo lahko pripišemo skupnemu faktorju »Tehnologija « oz. pojasnjeni varianci (preglednica 23).

Preglednica 23: Področje »Tehnologija « - komunalitete

\begin{tabular}{lcc} 
Trditev & Začetni & Po izločitvi faktorjev \\
$\begin{array}{l}\text { Tehnološke spremembe, ki se dogajajo v naši } \\
\text { panogi, so zelo velike. }\end{array}$ & 0,713 & 0,838 \\
$\begin{array}{l}\text { Tehnološke spremembe se v naši panogi } \\
\text { dogajajo zelo hitro. }\end{array}$ & 0,713 & 0,836 \\
$\begin{array}{l}\text { Tehnološke spremembe nam omogočajo veliko } \\
\text { novih priložnosti za rast našega podjetja. }\end{array}$ & 0,333 & 0,365 \\
\hline
\end{tabular}

Preglednica 24 in vse preglednice o komunalitetah dalje prikazujejo začetne vrednosti (pred izločitvijo) in vrednosti po izločitvi (združitvi oz. ekstrakciji) v en skupni faktor.Komunalitete pred izločitvijo so vse višje kot 0,3 , kar po Childu (2006) pomeni, da vse tri trditve lahko obdržimo $\mathrm{v}$ analizi. Celotna pojasnjena varianca za področje $\gg$ Tehnologija « prikazuje delež ohranjene variabilnosti, ko trditve združimo v en faktor (preglednica 24). 
Preglednica 24: Področje $»$ Tehnologija « - celotna pojasnjena varianca

\begin{tabular}{|c|c|c|c|c|c|c|}
\hline \multirow{2}{*}{ Faktor } & \multicolumn{3}{|c|}{ Začetne lastne vrednosti } & \multicolumn{3}{|c|}{$\begin{array}{l}\text { Vsota kvadriranih uteži po izločitvi } \\
\text { (po združitvi v en faktor) }\end{array}$} \\
\hline & Skupaj & $\%$ variance & $\begin{array}{c}\text { Kumulativa } \\
\text { v \% }\end{array}$ & Skupaj & $\%$ variance & $\begin{array}{c}\text { Kumulativa } \\
\text { v \% }\end{array}$ \\
\hline I & 2,306 & 76,858 & 76,858 & 2,039 & 67,975 & 67,975 \\
\hline 2 & 0,532 & 17,728 & 94,585 & & & \\
\hline 3 & 0,162 & 5,415 & 100,000 & & & \\
\hline
\end{tabular}

$\mathrm{V}$ našem primeru enim faktorjem pojasnimo $67,9 \%$ pojasnjene variance, kar pomeni, da podatki nakazujejo na enodimenzionalno strukturo področja »Tehnologija《.To pomeni, da so naše trditve znotraj področja dovolj povezane in da se vse združujejo v en faktor. Kolenski diagram je prikazan v prilogi 4 .

Matrika faktorskih uteži za področje »Tehnologija《 kaže, v kolikšni meri posamezna trditev znotraj področja »Tehnologija « doprinese skupnemu vplivu. Največji vpliv ima trditev »Tehnološke spremembe, ki se dogajajo v naši panogi, so zelo velike« (preglednica 25).

Preglednica 25: Področje »Tehnologija « - matrika faktorskih uteži

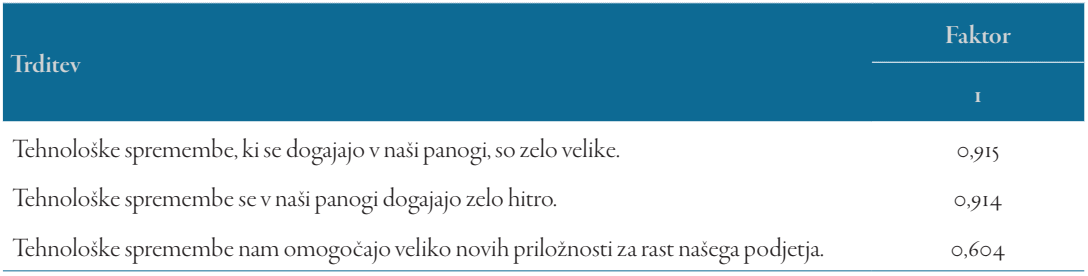

Dodatno interna konsistentnost (koeficient Cronbachova alfa $-\alpha$ ) $\mathrm{v}$ prilogi 6 prikazuje konsistentnost (zanesljivost oz. ponovljivost rezultatov ob podobnih podatkih) za področje »Tehnologija «. Parameter Cronbachova alfa je o,848, kar po Tavakolu in Dennicku (20 I , 53) pomeni, da je naš sklop trditev na področju »Tehnologija dovolj konsistenten (Priloga 4).

\section{Rezultatiocen napodročju »Dobavitelji《}

Dobavitelji v našem modelu povezav predstavljajo sestavni del dejavnika »Spremembe v okolju«, za katerega smo na podlagi raziskane literature in spoznanj v teoretičnem delu predpostavili, da ima vpliv na odvisno spremenljivko, to je strategijo podjetja do kupcev (slika r). Uvodoma predsta- 
vljamo rezultate analize povezanosti posameznih trditev in rezultate analize interne konsistentnosti, ki se nanašajo na področje »Dobavitelji $\ll$.

Rezultati povezanosti trditev za področje »Dobavitelji« kažejo, da so v našem primeru vse trditve, razen trditve »Konkurenčnost naših izdelkov/storitev je odvisna predvsem od inovativnosti naših dobaviteljev«, dovolj povezane. To kažejo vrednosti pod 0,3 (Yong in Pearce 2013, 7994). Za nadaljnjo analizo ohranimo samo trditve $\mathrm{z}$ vrednostmi nad 0,3 (preglednica 26).

Preglednica 26: Področje »Dobavitelji « - povezanost med trditvami

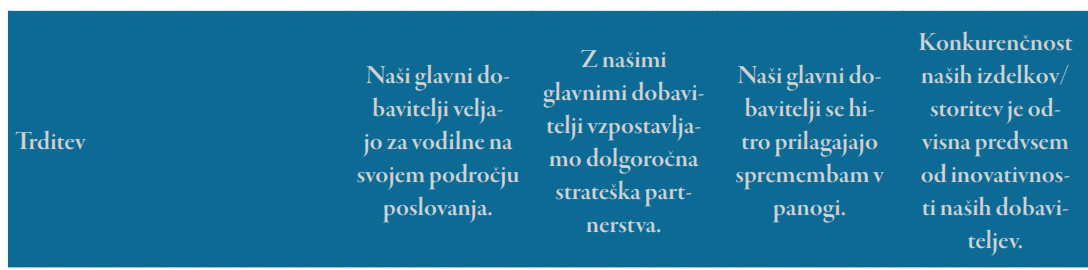

Naši glavni dobavitelji veljajo

za vodilne na svojem področju

1,000

poslovanja.

Z našimi glavnimi dobavitelji vz-

postavljamo dolgoročna strateška

partnerstva.

Naši glavni dobavitelji se hitro

prilagajajo spremembam v panogi.

1,000

Konkurenčnost naših izdelkov/

storitev je odvisna predvsem od in-

0,330

0,222

0,306

$\mathrm{I}, \mathrm{OOO}$

ovativnosti naših dobaviteljev.

Determinanta $=0,377$

$\mathrm{V}$ našem primeru je determinanta 0,377 , kar je po Yongu in Pearceu (2013, 79-94) nad 0,0000I in pomeni, da različne trditve znotraj področja »Dobavitelji « dejansko merijo različni vpliv ter so primerne za nadaljnjo analizo.

V naslednjem koraku trditev »Konkurenčnost naših izdelkov/storitev je odvisna predvsem od inovativnosti naših dobaviteljev« izločimo (odstranimo) s področja »Dobavitelji «. KMO in Bartlettov test sta nam za področje pomagala določiti, ali so trditve znotraj področja medsebojno dovolj povezane, da bi bila faktorska analiza v nadaljevanju smiselna (preglednica 27).

Za naš primer rezultati kažejo, da je KMO o,702, kar je nad o,5, prav tako je Bartlettov test statistično značilen, saj je p-vrednost pod o,os (pod $5 \%$ ). Iz tega sklenemo, da so trditve znotraj področja $\gg$ Dobavite- 
lji« medsebojno dovolj povezane in da je faktorska analiza v nadaljevanju smiselna.

\section{Preglednica 27: Področje »Dobavitelji « $-\mathrm{KMO}$ in Bartlettov test}

\begin{tabular}{lcc} 
Kaiser-Meyer-Olkinova mera vzorčne ustreznosti & & 0,702 \\
\hline Bartlettov test sferičnosti & Hi-kvadrat & $133,44 \mathrm{I}$ \\
& Stopinje prostosti & 3 \\
& p-vrednost & 0,000 \\
\hline
\end{tabular}

Analizirali smo tudi komunalitete. Te prikazujejo delež variance opazovanih trditev, ki jo lahko pripišemo skupnemu faktorju »Dobavitelji« oz. pojasnjeni varianci (preglednica 28). Začetne komunalitete so vse višje kot 0,3 , kar po Childu (2006) pomeni, da trditve lahko obdržimo v analizi.

Preglednica 28: Področje »Dobavitelji $\ll-$ komunalitete

\begin{tabular}{lcc} 
Trditev & Začetni & $\begin{array}{c}\text { Po izločitvi } \\
\text { faktorjev }\end{array}$ \\
$\begin{array}{l}\text { Naši glavni dobavitelji veljajo za vodilne na svojem področju } \\
\text { poslovanja. }\end{array}$ & 0,367 & 0,5 II \\
$\begin{array}{l}\text { Znašimi glavnimi dobavitelji vzpostavljamo dolgoročna strateška } \\
\text { partnerstva. }\end{array}$ & 0,406 & 0,593 \\
\begin{tabular}{l} 
Naši glavni dobavitelji se hitro prilagajajo spremembam v panogi. \\
\hline
\end{tabular} & 0,376 & 0,527 \\
\hline
\end{tabular}

Celotna pojasnjena varianca za področje »Dobavitelji« prikazuje delež ohranjene variabilnosti, ko trditve združimo v en faktor (preglednica 29). V našem primeru enim faktorjem pojasnimo $54,3 \%$ pojasnjene variance, kar pomeni, da podatki nakazujejo na enodimenzionalno strukturo področja »Dobavitelji «. To pomeni, da so naše trditve znotraj področja $\gg$ Dobavitelji« dovolj povezane in da se vse trditve združujejo v en faktor.

Preglednica 29: Področje »Dobavitelji $\ll$ - celotna pojasnjena varianca

\begin{tabular}{ccccccc} 
& \multicolumn{3}{c}{ Začetne lastne vrednosti } & \multicolumn{2}{c}{$\begin{array}{c}\text { Vsota kvadriranih uteži po izločitvi } \\
\text { Faktor }\end{array}$} & (po združitviv en faktor) \\
\cline { 2 - 6 } & Skupaj & \% variance & $\begin{array}{c}\text { Kumulativa } \\
\text { v \% }\end{array}$ & Skupaj & $\%$ variance & $\begin{array}{c}\text { Kumulativa } \\
\text { v \% }\end{array}$ \\
\hline I & 2,086 & 69,517 & 69,517 & 1,630 & 54,347 & 54,347 \\
2 & 0,482 & 16,083 & 85,601 & & \\
3 & 0,432 & 14,399 & 100,000 & & \\
\hline
\end{tabular}


Matrika faktorskih uteži za področje »Dobavitelji« kaže, v kolikšni meri posamezna trditev znotraj področja prispeva $\mathrm{k}$ skupnemu vplivu. Največji vpliv ima trditev $\gg Z$ našimi glavnimi dobavitelji vzpostavljamo dolgoročna strateška partnerstva $\ll$ (preglednica 30).

Preglednica 30: Področje »Dobavitelji $\ll$ - matrika faktorskih uteži

\begin{tabular}{|c|c|}
\hline \multirow{2}{*}{ Trditev } & Faktor \\
\hline & I \\
\hline Z našimi glavnimi dobavitelji vzpostavljamo dolgoročna strateška partnerstva. & 0,770 \\
\hline Naši glavni dobavitelji se hitro prilagajajo spremembam v panogi. & 0,726 \\
\hline Naši glavni dobavitelji veljajo za vodilne na svojem področju poslovanja. & 0,715 \\
\hline
\end{tabular}

Dodatno interna konsistentnost (Cronbachova alfa $-\alpha$ ) v prilogi 6 prikazuje konsistentnost (zanesljivost oz. ponovljivost rezultatov ob podobnih podatkih) za področje »Dobavitelji «. Parameter Cronbachova alfa je v našem primeru 0,780 , kar pomeni, da je naš sklop trditev na področju »Dobavitelji « dovolj konsistenten za nadaljnjo analizo.

Če povzamemo opravljeno analizo konsistentnosti in povezanosti trditev znotraj vsakega dejavnika, lahko rečemo naslednje: naš sklop trditev za področje $\gg$ Kupci« je premalo konsistenten. Pri področju »Kupci« torej ne moremo govoriti o enodimenzionalnosti, ampak bomo posamezne trditve na področju »Kupci« skozi analizo obravnavali ločeno. To se je zgodilo kljub temu, da smo izhajali iz predhodnih raziskav in trditev, ki so jih v svojih raziskavah uporabili drugi raziskovalci (Jaworski in Kohli 1993; Li in Calantone 1998; Danneels in Sethi 2003; Strecker 2009). Kljub podobni stopnji odzivnosti anketirancev (\%) imajo podobne raziskave v večjih ekonomijah ob podobni stopnji odzivnosti številčno večji vzorec. Ocenjujemo, da bi lahko ta pomembno vplival na konsistentnost. Naš okvir raziskave je po drugi strani edinstven: vezan je na izbor posameznih dejavnikov okolja (slika I), prav tako je edinstven, ker gre za drugo ekonomijo (glede na omejitve raziskave, saj se osredotočamo na MSP v Sloveniji). Za področje »Konkurenti« analiza KMO in Bartlettov test kažeta, da so trditve znotraj medsebojno dovolj povezane in da je faktorska analiza v nadaljevanju smiselna. Enako velja za področji $\gg$ Tehnologija $\ll$ in $\gg$ Dobavitelji $\ll$.

\section{Preverjanje teoretičnega modela za dejavnik »Strategija podjetja do kupcev $\ll$}

Glede na naš razviti model povezav (slika ı) smo za dejavnik »Strategija podjetja do kupcev«, ki zajema področja »Strategija diferenciacije $\ll$, 
»Strategija nizkih stroškov in privlačnih cen «, »Strategija osredinjenja $\ll$ ter $\gg$ Strategija prehitevanja $\ll$, najprej preverili, ali so posamezne trditve za področja dovolj povezane, da bi bila faktorska analiza v nadaljevanju smiselna. Preverili smo še interno konsistentnost (zanesljivost oz. ponovljivost) rezultatov ob podobnih podatkih, ki jih merimo s parametrom Cronbachova alfa $-\alpha$. Za vsako izmed področij »Strategija diferenciacije «, »Strategija nizkih stroškov in privlačnih cen«, »Strategija osredinjenja $\ll$ ter $\gg$ Strategija prehitevanja $\ll$ predstavljamo rezultate analize $v$ obliki preglednic in komentarjev.

Sledi predstavitev rezultatov analize dejavnika $\gg$ Strategija podjetja do kupcev «, ki zajema področja $\gg$ Strategija diferenciacije $\ll, ~ \gg$ Strategija nizkih stroškov in privlačnih cen «, »Strategija osredinjenja « ter »Strategija prehitevanja $\ll$.

\section{Rezultati ocen na področju »Strategija diferenciacije«}

Strategija diferenciacije v našem modelu povezav predstavlja sestavni del dejavnika »Strategija podjetja do kupcev«, za katerega smo na podlagi raziskane literature in spoznanj v teoretičnem delu predpostavili, da ima vpliv na odvisno spremenljivko, to je uspešnost podjetja (slika i). Uvodoma predstavljamo rezultate analize povezanosti posameznih trditev in rezultate analize interne konsistentnosti, ki se nanašajo na področje »Strategija diferenciacije $\ll$.

$\mathrm{V}$ našem primeru so vse trditve, razen trditve $\gg$ Naši izdelki/storitve so bistveno drugačni od našega glavnega tekmeca v panogi $\ll$, med seboj dovolj povezane. Šibko povezanost kažejo vrednosti pod o,3. V naslednjem koraku za nadaljnje analize omenjeno trditev izločimo (odstranimo) iz področja »Strategija diferenciacije« (preglednica 3i). V našem primeru je determinanta 0,300 in pomeni, da različne trditve znotraj področja »Strategija diferenciacije« dejansko merijo različen vpliv in so primerne za nadaljnjo analizo.

$\mathrm{V}$ naslednjem koraku trditev $\gg \mathrm{Naši} \mathrm{izdelki/storitve} \mathrm{so} \mathrm{bistveno} \mathrm{dru-}$ gačni od našega glavnega tekmeca v panogi « za nadaljnjo analizo izločimo (odstranimo) s področja »Strategija diferenciacije $\ll$. KMO in Bartlettov test sta nam za področje »Strategija diferenciacije« pomagala določiti, ali so trditve znotraj področja »medsebojno dovolj povezane, da bi bila faktorska analiza $v$ nadaljevanju smiselna. Za naš primer rezultati kažejo, da je KMO o,697, kar je nad o,5, prav tako je Bartlettov test statistično značilen, saj je p-vrednost pod o,05 (pod $5 \%$ ) (preglednica 32). Iz tega sklenemo, da so trditve znotraj področja »Strategija diferenciacije $\ll$ medsebojno dovolj povezane in da je faktorska analiza v nadaljevanju smiselna. 
Strategije in uspešnost podjetja

\section{Preglednica 31: Področje »Strategija diferenciacije« - povezanost med trditvami}

\begin{tabular}{|c|c|c|c|c|}
\hline Trditev & $\begin{array}{l}\text { Naši izdelki/ } \\
\text { storitve so bistve- } \\
\text { no drugačni od } \\
\text { našega glavne- } \\
\text { ga tekmeca v } \\
\text { panogi. }\end{array}$ & $\begin{array}{l}\text { Pri trženju smo } \\
\text { inovativnejši kot } \\
\text { naš glavni tek- } \\
\text { mec v panogi. }\end{array}$ & $\begin{array}{l}\text { Stremimo k pre- } \\
\text { poznavnosti } \\
\text { lastne blagovne } \\
\text { znamke. }\end{array}$ & $\begin{array}{l}\text { Več vlagamov } \\
\text { marketinško ko- } \\
\text { municiranje kot } \\
\text { naš glavni tek- } \\
\text { mec v panogi. }\end{array}$ \\
\hline
\end{tabular}

Naši izdelki/storitve so bistveno drugačni od našega glavnega 1,000 tekmeca v panogi.

Pri trženju smo bolj inovativni kot naš glavni tekmec v panogi.

$$
0,460
$$

I,OOO

Stremimo k prepoznavnosti lastne blagovne znamke.

0,165

0,274

komuniciranje kot naš glavni tekmec v panogi.

Determinanta $=0,300$

Preglednica 32: Področje »Strategija diferenciacije « - KMO in Bartlettov test

Kaiser-Meyer-Olkinova mera vzorčne ustreznosti

Bartlettov test sferičnosti

\section{0,697}

153,658

$\begin{array}{cc}\text { Hi-kvadratz } & 153,658 \\ \text { Stopinje prostosti } & 3 \\ \text { p-vrednost } & 0,000\end{array}$

Analizirali smo tudi komunalitete. Te prikazujejo delež variance opazovanih trditev, ki jo lahko pripišemo skupnemu faktorju »Strategija diferenciacije « oz. pojasnjeni varianci (preglednica 33). Komunalitete pred ekstrakcijo so vse višje od ${ }_{0,3}$, kar pomeni, da lahko trditve obdržimo v analizi.

Preglednica 33: Področje »Strategija diferenciacije « - komunalitete

\section{Trditev}

Začetni

Po izločitvi faktorjev

Pri trženju smo inovativnejši kot naš glavni tekmec v panogi.

$0,426 \quad 0,555$

Stremimo k prepoznavnosti lastne blagovne znamke.

0,367

0,466

Več vlagamo v marketinško komuniciranje kot naš glavni

tekmec v panogi.

0,484

0,7 II 
Celotna pojasnjena varianca za področje $\gg$ Strategija diferenciacije $\ll$ prikazuje delež ohranjene variabilnosti, ko trditve združimo v en faktor (preglednica 34).

Preglednica 34: Področje »Strategija diferenciacije « - celotna pojasnjena varianca

\begin{tabular}{|c|c|c|c|c|c|c|}
\hline \multirow{2}{*}{ Faktor } & \multicolumn{3}{|c|}{ Začetne lastne vrednosti } & \multicolumn{3}{|c|}{$\begin{array}{l}\text { Vsota kvadriranih uteži po izločitvi } \\
\text { (po združitvi v en faktor) }\end{array}$} \\
\hline & Skupaj & $\%$ variance & $\begin{array}{c}\text { Kumulativa } \\
\text { v \% }\end{array}$ & Skupaj & $\%$ variance & $\begin{array}{c}\text { Kumulativa } \\
\text { v \% }\end{array}$ \\
\hline I & 2,143 & 71,425 & 71,425 & $\mathrm{I}, 73 \mathrm{I}$ & 57,717 & 57,717 \\
\hline 2 & 0,499 & 16,624 & 88,049 & & & \\
\hline 3 & 0,359 & II,95I & 100,000 & & & \\
\hline
\end{tabular}

$\mathrm{Z}$ enim faktorjem pojasnimo 57,71 \% pojasnjene variance, kar pomeni, da podatki nakazujejo na enodimenzionalno strukturo področja »Strategija diferenciacije«. Trditve za nadaljnjo analizo lahko združimo $\mathrm{v}$ en faktor.

Matrika faktorskih uteži za področje »Strategija diferenciacije« kaže, v kolikšni meri posamezna trditev znotraj področja prispeva k skupnemu vplivu. Največji vpliv ima trditev »Več vlagamo v marketinško komuniciranje kot naš glavni tekmec v panogi« (preglednica 35).

Preglednica 35: Področje »Strategija diferenciacije « - matrika faktorskih uteži

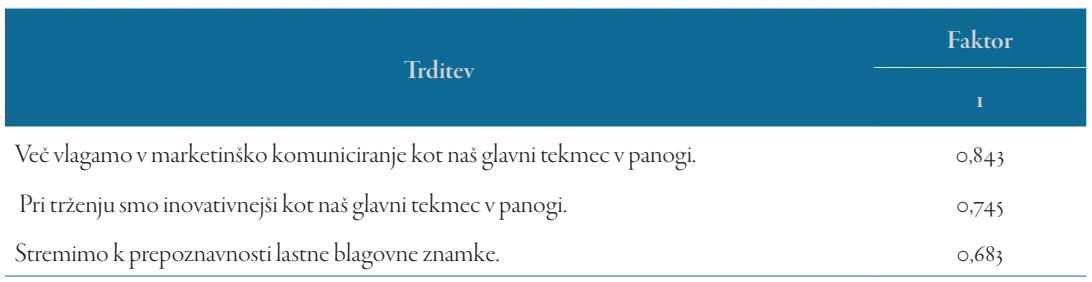

Interna konsistentnost (parameter Cronbachova alfa $-\alpha$ ) prikazuje konsistentnost (zanesljivost oz. ponovljivost rezultatov ob podobnih podatkih) za področje $\gg$ Strategija diferenciacije $\ll$. Parameter Cronbachova alfa je v našem primeru o,800, kar po Tavakolu in Dennicku (20 I , 53) pomeni, da je naš sklop trditev za področje »Strategija diferenciacije« dovolj konsistenten (priloga 6). 


\section{Rezultati ocen na področju »Strategija nizkih stroškov in privlačnih cen《}

Strategija nizkih stroškov in privlačnih cen $\mathrm{v}$ našem modelu povezav predstavlja sestavni del dejavnika »Strategija podjetja do kupcev«, za katerega smo na podlagi raziskane literature in spoznanj $v$ teoretičnem delu predpostavili, da ima vpliv na odvisno spremenljivko, to je uspešnost podjetja (slika I). Uvodoma predstavljamo rezultate analize povezanosti posameznih trditev in rezultate analize interne konsistentnosti, ki se nanašajo na področje $\gg$ Strategija nizkih stroškov in privlačnih cen«.

Preglednica 36 prikazuje rezultate analize povezanosti med posameznimi trditvami znotraj področja. Povezanost med trditvami je relativno šibka, kar kažejo vrednosti pod o,3 (preglednica 36). V našem primeru je determinanta 0,580 , kar je po Yongu in Pearceu (2013, 79-94) nad $0,0000 \mathrm{I}$ in pomeni, da različne trditve znotraj področja merijo različen vpliv ter so primerne za nadaljnjo analizo. V naslednjem koraku iz področja izločimo (odstranimo) prvo in drugo trditev: $\gg V$ podjetju smo pri izvajanju poslovnih aktivnosti visoko učinkoviti (produktivni) « ter $\gg \mathrm{Na}$ trgu konkuriramo z nizkimi cenami naših izdelkov/storitev«.

Preglednica 36: Področje »Strategija nizkih stroškov in privlačnih cen «- povezanost med trditvami

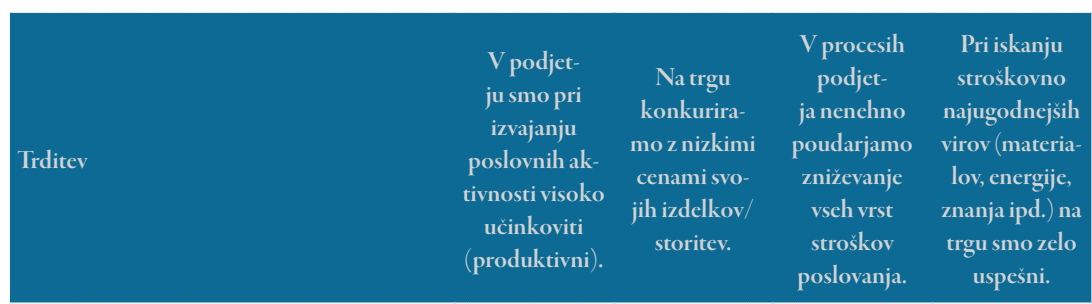

V podjetju smo pri izvajanju poslovnih aktivnosti visoko učinkoviti (produktivni).

1,000

Na trgu konkuriramo z nizkimi cenami svojih izdelkov/storitev.

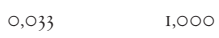

V procesih podjetja nenehno poudarjamo zniževanje vseh vrst stroškov poslovanja.

Pri iskanju stroškovno najugodnejših virov (materialov, energije, znanja ipd.) na trgu smo zelo uspešni.

Determinanta $=0,580$

KMO in Bartlettov test sta nam za področje »Strategija nizkih stroškov in privlačnih cen « pomagala določiti, ali so trditve znotraj področja 
medsebojno dovolj povezane, da bi bila faktorska analiza v nadaljevanju smiselna (preglednica 37).

Preglednica 37: Področje »Strategija nizkih stroškov in privlačnih cen « - KMO in

Bartlettov test

\begin{tabular}{lcc}
\hline Kaiser-Meyer-Olkinova mera vzorčne ustreznosti & & 0,500 \\
\hline Bartlettov test sferičnosti & Hi-kvadrat & $4 \mathrm{I}, 649$ \\
& Stopinje prostosti & $\mathrm{I}$ \\
& p-vrednost & 0,000 \\
\hline
\end{tabular}

Za naš primer rezultati kažejo, da je KMO o,500, kar je nad o,5, prav tako je Bartlettov test statistično značilen, saj je p-vrednost pod o,os (pod $5 \%)$. Iz tega sklenemo, da so trditve znotraj področja medsebojno dovolj povezane in da je faktorska analiza v nadaljevanju smiselna.

Analizirali smo tudi komunalitete. Te prikazujejo delež variance opazovanih trditev, ki jo lahko pripišemo skupnemu faktorju »Strategija nizkih stroškov in privlačnih cen $\ll$ oz. pojasnjeni varianci (preglednica 38). Komunalitete pred ekstrakcijo so nižje od o,3, toda na podlagi drugih kriterijev (povezanost med trditvami glede na vrednosti, ponavljanje vrednosti pod o,3 pri enaki trditvi, zanesljivost koeficienta Cronbachova alfa) se odločimo, da trditvi vseeno obdržimo.

Preglednica 38: Področje »Strategija nizkih stroškov in privlačnih cen «- komunalitete

\begin{tabular}{lll} 
Trditev & Začetni & $\begin{array}{c}\text { Po izločitvi } \\
\text { faktorjev }\end{array}$ \\
$\begin{array}{l}\text { V procesih podjetja nenehno poudarjamo zniževanje vseh vrst } \\
\text { stroškov poslovanja. }\end{array}$ & 0,229 & 0,477 \\
$\begin{array}{l}\text { Pri iskanju stroškovno najugodnejših virov (materialov, energije, } \\
\text { znanja ipd.) na trgu smo zelo uspešni. }\end{array}$ & 0,229 & 0,477 \\
\hline
\end{tabular}

Celotna pojasnjena varianca za področje $\gg$ Strategija nizkih stroškov in privlačnih cen« prikazuje delež ohranjene variabilnosti, ko trditve združimo v en faktor (preglednica 39). Z enim faktorjem pojasnimo 47,7 $\%$ pojasnjene variance, kar pomeni, da podatki nakazujejo na enodimenzionalno strukturo področja. Trditve za nadaljnjo analizo lahko združimo v en faktor.

Matrika faktorskih uteži za področje »Strategija nizkih stroškov in privlačnih cen« kaže, v kolikšni meri posamezna trditev znotraj področja prispeva k skupnemu vplivu (preglednica 40). 
Preglednica 39: Področje »Strategija nizkih stroškov in privlačnih cen « - celotna pojasnjena varianca

\begin{tabular}{ccccccc} 
& \multicolumn{2}{c}{ Začetne lastne vrednosti } & \multicolumn{2}{c}{$\begin{array}{c}\text { Vsota kvadriranih uteži po izločitvi } \\
\text { (po združitvi v en faktor) }\end{array}$} \\
\cline { 2 - 7 } & Skupaj & $\%$ variance & $\begin{array}{c}\text { Kumulativa } \\
\text { v } \%\end{array}$ & Skupaj & $\%$ variance & $\begin{array}{c}\text { Kumulativa } \\
\text { v \% }\end{array}$ \\
\hline 1 & 1,478 & 73,904 & 73,904 & 0,954 & 47,711 & 47,7 II \\
2 & 0,522 & 26,096 & 100,000 & & & \\
\hline
\end{tabular}

Preglednica 40: Področje »Strategija nizkih stroškov in privlačnih cen « - matrika faktorskih uteži

V procesih podjetja nenehno poudarjamo zniževanje vseh vrst stroškov poslovanja.

Interna konsistentnost (Cronbachoca alfa $-\alpha$ ) kaže konsistentnost (zanesljivost oz. ponovljivost rezultatov ob podobnih podatkih) za področje. Parameter Cronbachova alfa je v našem primeru o,643, kar pomeni, da je naš sklop trditev za področje »Strategija nizkih stroškov in privlačnih cen« dovolj konsistenten (Priloga 6).

\section{Rezultati ocen na področju $\gg$ Strategija osredinjenja《}

Strategija osredinjanja v našem modelu povezav predstavlja sestavni del dejavnika $\gg$ Strategija podjetja do kupcev«, za katerega smo na podlagi raziskane literature in spoznanj $\mathrm{v}$ teoretičnem delu predpostavili, da ima vpliv na odvisno spremenljivko, to je uspešnost podjetja (slika I). Uvodoma predstavljamo rezultate analize povezanosti posameznih trditev in rezultate analize interne konsistentnosti, ki se nanašajo na področje »Strategija osredinjenja «. Rezultati analize kažejo, da je povezanost med trditvami znotraj področja relativno dobra, $\mathrm{z}$ manjšo izjemo, ki pa se ne ponavlja. Zaznano je le manjše neujemanje med trditvijo 3 in 4 (preglednica $4 \mathrm{I})$.

Ker se nepovezanost po več kriterijih ne ponavlja pri drugih trditvah in ker je $\mathrm{v}$ tem primeru povezanost med trditvijo 4 in drugimi trditvami večja od o,3, ni potrebe po izključitvi trditve 3 ali 4 . V nadaljnji anali- 
zi zato pustimo vse trditve. $V$ našem primeru je determinanta 0,42 , kar je po Yongu in Pearceu $(2013,79-94)$ nad o,0000I in pomeni, da različne trditve znotraj področja »Strategija osredinjenja $\ll$ dejansko merijo različni vpliv in so primerne za nadaljnjo analizo.

Preglednica 41: Področje »Strategija osredinjenja« - povezanost med trditvami

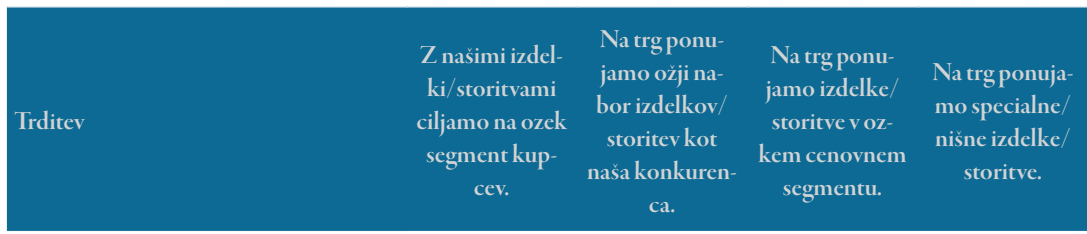

Z našimi izdelki/storitvami ciljamo na ozek segment kupcev.

I,OOO

Na trg ponujamo ožji nabor izdelkov/ storitev kot naša konkurenca.

0,460

1,000

Na trg ponujamo izdelke/storitve v

ozkem cenovnem segmentu.

0,453

0,493

$\mathrm{I}, 000$

Na trg ponujamo specialne/nišne

izdelke/storitve.

0,447

0,307

Determinanta $=0,42 \mathrm{I}$

KMO in Bartlettov test sta nam za področje »Strategija osredinjenja《 pomagala določiti, ali so trditve medsebojno dovolj povezane, da bi bila faktorska analiza v nadaljevanju smiselna. (preglednica 42).

Preglednica 42: Področje »Strategija osredinjenja $-\mathrm{KMO}$ in Bartlettov test

\begin{tabular}{lcc} 
Kaiser-Meyer-Olkinova mera vzorčne ustreznosti & & 0,669 \\
\hline Bartlettov test sferičnosti & Hi-kvadrat & 138,179 \\
& Stopinje prostosti & 6 \\
& p-vrednost & 0,000 \\
\hline
\end{tabular}

Za naš primer rezultati kažejo, da je $\mathrm{KMO}$ 0,500, kar je nad o,5, prav tako je Bartlettov test statistično značilen, saj je p-vrednost pod o,05 (pod 5\%). Iz tega sklenemo, da so trditve znotraj področja $\gg S t r a t e g i j a$ osredinjenja « medsebojno dovolj povezane in da je faktorska analiza $\mathrm{v}$ nadaljevanju smiselna.

Analizirali smo tudi komunalitete. Te prikazujejo delež variance opazovanih trditev, ki jo lahko pripišemo skupnemu faktorju »Strategija osredinjenja $\ll$ oz. pojasnjeni varianci (preglednica 43). 


\begin{tabular}{lcc} 
Trditev & Začetni & Po izločitvi faktorjev \\
Z našimi izdelki/storitvami ciljamo na ozek segment kupcev. & 0,385 & 0,586 \\
Na trg ponujamo ožji nabor izdelkov/storitev kot naša & 0,333 & 0,471 \\
konkurenca. & & 0,352 \\
Na trg ponujamo izdelke/storitve v ozkem cenovnem segmentu. & 0,321 & 0,203 \\
Na trg ponujamo specialne/nišne izdelke/storitve. & 0,228 & \\
\hline
\end{tabular}

Komunalitete pred ekstrakcijo so za področje »Strategija osredinjenja « večinoma nad o,3, z izjemo zadnje trditve, toda na podlagi drugih kriterijev (povezanost med trditvami glede na vrednosti, ponavljanje vrednosti pod 0,3 pri enaki trditvi, zanesljivost koeficienta Cronbachova alfa) se odločimo, da trditev vseeno obdržimo (priloga 6).

Celotna pojasnjena varianca za področje $\gg$ Strategija osredinjenja $\ll$ prikazuje delež ohranjene variabilnosti, ko trditve združimo v en faktor (preglednica 44). Z enim faktorjem pojasnimo $40,3 \%$ pojasnjene variance, kar pomeni, da podatki nakazujejo na enodimenzionalno strukturo področja. Trditve znotraj področja za nadaljnjo analizo lahko združimov en faktor.

Preglednica 44: Področje »Strategija osredinjenja $\ll$ - celotna pojasnjena varianca

\begin{tabular}{|c|c|c|c|c|c|c|}
\hline \multirow{2}{*}{ Faktor } & \multicolumn{3}{|c|}{ Začetne lastne vrednosti } & \multicolumn{3}{|c|}{$\begin{array}{l}\text { Vsota kvadriranih uteži po izločitvi } \\
\text { (po združitvi v en faktor) }\end{array}$} \\
\hline & Skupaj & $\%$ variance & $\begin{array}{c}\text { Kumulativa } \\
\mathbf{v} \%\end{array}$ & Skupaj & $\%$ variance & $\begin{array}{c}\text { Kumulativa } \\
\text { v \% }\end{array}$ \\
\hline I & 2,169 & 54,230 & 54,230 & 1,612 & 40,309 & 40,309 \\
\hline 2 & 0,892 & 22,308 & 76,538 & & & \\
\hline 3 & 0,520 & 12,996 & 89,533 & & & \\
\hline 4 & 0,419 & 10,467 & 100,000 & & & \\
\hline
\end{tabular}

Matrika faktorskih uteži za področje »Strategija osredinjenja《kaže, $\mathrm{v}$ kolikšni meri posamezna trditev znotraj področja prispeva $\mathrm{k}$ skupnemu vplivu. Največji vpliv ima trditev $\gg Z$ našimi izdelki/storitvami ciljamo na ozek segment kupcev« (preglednica 45).

Interna konsistentnost (Cronbachova alfa $-\alpha$ ) prikazuje konsistentnost (zanesljivost oz. ponovljivost rezultatov ob podobnih podatkih) za področje »Strategija osredinjenja «. Parameter Cronbachov alfa je v našem primeru o,7 IO, kar pomeni, da je naš sklop trditev za področje dovolj konsistenten za nadaljnjo analizo (priloga 6). 


\begin{tabular}{ll} 
Trditev & \multicolumn{2}{c}{ Faktor } \\
\cline { 2 - 2 } Z našimi izdelki/storitvami ciljamo na ozek segment kupcev. & I \\
Na trg ponujamo ožji nabor izdelkov/storitev kot naša konkurenca. & 0,765 \\
Na trg ponujamo izdelke/storitve v ozkem cenovnem segmentu. & 0,686 \\
Na trg ponujamo specialne/nišne izdelke/storitve. & 0,594 \\
\hline
\end{tabular}

\section{Rezultati ocen na področju »Strategija prehitevanja《}

Strategija prehitevanja v našem modelu povezav predstavlja sestavni del dejavnika »Strategija podjetja do kupcev«, za katerega smo na podlagi raziskane literature in spoznanj v teoretičnem delu predpostavili, da ima vpliv na odvisno spremenljivko, to je uspešnost podjetja (slika i). Uvodoma predstavljamo rezultate analize povezanosti posameznih trditev in rezultate analize interne konsistentnosti, ki se nanašajo na področje »Strategija prehitevanja $\ll$.

Preglednica 46 kaže rezultate analize povezanosti na področju »Strategija prehitevanja $\ll$. V našem primeru je povezanost med trditvami $\mathrm{v}$ vseh primerih zelo močna, saj so vse vrednosti nad o,3. V našem primeru je determinanta 0,022 , kar je nad $0,0000 \mathrm{I}$ in pomeni, da različne trditve znotraj področja merijo različni vpliv (ne merijo enega in istega) in so primerne za nadaljnjo analizo.

\section{Preglednica 46: Področje »Strategija prehitevanja « - povezanost med trditvami}

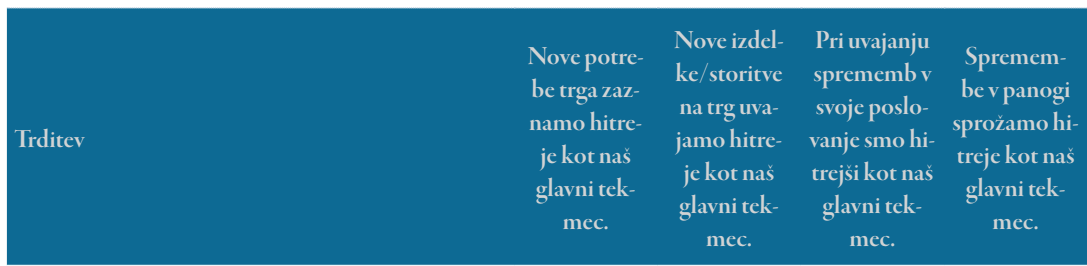

Nove potrebe trga zaznamo hitreje kot naš glavni tekmec.

Nove izdelke/storitve na trg uvajamo hitreje kot naš glavni tekmec. $0,862 \quad 1,000$

Pri uvajanju sprememb v svoje poslovanje smo hitrejši kot naš glavni tekmec. 
KMO in Bartlettov test sta nam za področje »Strategija prehitevanja « pomagala določiti, ali so trditve znotraj področja medsebojno dovolj povezane, da bi bila faktorska analiza v nadaljevanju smiselna (preglednica 47). Za naš primer rezultati kažejo, da je $\mathrm{KMO}$ o,825, kar je nad o,5, prav tako je Bartlettov test statistično značilen, saj je p-vrednost pod 0,05 (pod $5 \%$ ). Iz tega izhaja, da so trditve znotraj področja »Strategija osredinjenja « medsebojno dovolj povezane in da je faktorska analiza $\mathrm{v}$ nadaljevanju smiselna.

Preglednica 47: Področje »Strategija prehitevanja $-\mathrm{KMO}$ in Bartlettov test

\begin{tabular}{lcc} 
Kaiser-Meyer-Olkinova mera vzorčne ustreznosti & & 0,825 \\
\hline Bartlettov test sferičnosti & Hi-kvadrat & 608,888 \\
& Stopinje prostosti & 6 \\
& p-vrednost & 0,000 \\
\hline
\end{tabular}

Analizirali smo tudi komunalitete. Te prikazujejo delež variance opazovanih trditev, ki jo lahko pripišemo skupnemu faktorju »Strategija prehitevanja $\ll$ oz. pojasnjeni varianci (preglednica 48). Komunalitete za področje »Strategija prehitevanja« prikazujejo delež variance opazovanih trditev, ki jo lahko pripišemo skupnemu faktorju oz. celotni varianci (preglednica 59). Komunalitete pred ekstrakcijo za področje »Strategija prehitevanja so vse nad o,3. Odločimo se, da vse štiri trditve za nadaljnjo analizo obdržimo.

Preglednica 48: Področje »Strategija prehitevanja « - komunalitete

\begin{tabular}{lcc} 
Trditev & Začetni & Po izločitvi faktorjev \\
$\begin{array}{l}\text { Nove potrebe trga zaznamo hitreje kot naš glavni tekmec. } \\
\begin{array}{l}\text { Nove izdelke/storitve na trg uvajamo hitreje kot naš glavni } \\
\text { tekmec. }\end{array}\end{array}$ & 0,782 & 0,815 \\
$\begin{array}{l}\text { Pri uvajanju sprememb v svoje poslovanje smo hitrejši kot naš } \\
\text { glavni tekmec. }\end{array}$ & 0,775 & 0,802 \\
\begin{tabular}{l} 
Spremembe v panogi sprožamo hitreje kot naš glavni tekmec. \\
\hline
\end{tabular} & 0,782 & 0,750 \\
\hline
\end{tabular}

Celotna pojasnjena varianca za področje »Strategija prehitevanja« prikazuje delež ohranjene variabilnosti, ko trditve združimo v en faktor (preglednica 49). Z enim faktorjem pojasnimo 79,9 \% pojasnjene variance, kar pomeni, da podatki nakazujejo na enodimenzionalno strukturo področja »Strategija prehitevanja«. Trditve se združujejo v en faktor. Dodatno je kolenski diagram prikazan v prilogi 4 . 
Preglednica 49: Področje »Strategija prehitevanja « - celotna pojasnjena varianca

\begin{tabular}{|c|c|c|c|c|c|c|}
\hline \multirow{2}{*}{ Faktor } & \multicolumn{3}{|c|}{ Začetne lastne vrednosti } & \multicolumn{3}{|c|}{$\begin{array}{l}\text { Vsota kvadriranih uteži po izločitvi } \\
\text { (po združitvi v en faktor) }\end{array}$} \\
\hline & Skupaj & $\%$ variance & $\begin{array}{c}\text { Kumulativa } \\
\mathbf{v} \%\end{array}$ & Skupaj & $\%$ variance & $\begin{array}{c}\text { Kumulativa } \\
\text { v \% }\end{array}$ \\
\hline I & 3,397 & 84,929 & 84,929 & 3,197 & 79,929 & 79,929 \\
\hline 2 & 0,315 & 7,866 & 92,795 & & & \\
\hline 3 & 0,150 & 3,752 & 96,546 & & & \\
\hline 4 & 0,138 & 3,454 & 100,000 & & & \\
\hline
\end{tabular}

Matrika faktorskih uteži za področje »Strategija prehitevanja« kaže, v kolikšni meri posamezna trditev znotraj področja prispeva k skupnemu vplivu. Največji vpliv ima trditev »Spremembe v panogi sprožamo hitreje kot naš glavni tekmec« (preglednica 50).

Preglednica 50: Področje »Strategija prehitevanja« - matrika faktorskih uteži

\begin{tabular}{|c|c|}
\hline \multirow{2}{*}{ Trditev } & Faktor \\
\hline & I \\
\hline Spremembe v panogi sprožamo hitreje kot naš glavni tekmec. & 0,911 \\
\hline Nove potrebe trga zaznamo hitreje kot naš glavni tekmec. & 0,903 \\
\hline Nove izdelke/storitve na trg uvajamo hitreje kot naš glavni tekmec. & 0,896 \\
\hline Pri uvajanju sprememb v svoje poslovanje smo hitrejši kot naš glavni tekmec. & 0,866 \\
\hline
\end{tabular}

Interna konsistentnost (Cronbachova alfa $-\alpha$ ) v prilogi 6 prikazuje konsistentnost (zanesljivost oz. ponovljivost rezultatov ob podobnih podatkih) za področje $\gg$ Strategija prehitevanja $\ll$. Parameter Cronbachovova alfa je v našem primeru 0,94I, kar pomeni, da je naš sklop trditev na področju dovolj konsistenten za nadaljnjo analizo.

Če povzamemo, smo preučili konsistentnost in povezanost za dejavnik »Strategija podjetja do kupcev«, ki vključuje področja »Strategija diferenciacije $\ll$, 》Strategija nizkih stroškov in privlačnih cen «, »Strategija osredinjenja $\ll$ in $\gg$ Strategija prehitevanja $\ll$. KMO in Bartlettov test za vsako izmed teh področij sta pokazala, da so trditve znotraj področij medsebojno dovolj povezane in da je faktorska analiza za vsakega izmed teh dejavnikov v nadaljevanju smiselna. Trditve znotraj posameznih področij se združujejo v en faktor. 



\section{Povzetek ugotovitev raziskave}

V sklepnem delu naloge podajamo skupno poročilo o preverjanju hipoteze, interpretiramo rezultate, povzamemo spoznanja raziskave, podajamo implikacije za delo v praksi, opisujemo prispevek k znanosti ter dajemo usmeritve za nadaljnja raziskovanja na tem področju.

\section{Povzetek o preverjanju zastavljenega modela in interpretacija rezultatov}

Naš model povezav med izbranimi dejavniki sprememb v okolju, strategijami podjetja do kupcev in uspešnostjo podjetja (slika I) smo najprej vnesli v strukturni model. Skozi analizo se je uvodoma izkazalo, da dejavnika $\gg$ Spremembe v okolju « in »Strategija podjetja do kupcev«, kot enotna dejavnika večjega števila spremenljivk, nimata statistično značilnega vpliva na katero izmed izbranih odvisnih spremenljivk, ki merijo uspešnost podjetja (ROA, ROE, EVA, BON). Zato smo v nadaljevanju model postopoma izboljševali, vpliv na uspešnost podjetja pa smo raziskali na ravni posameznih trditev (spremenljivk).

Model smo izboljševali tako, da smo s pomočjo postopnega izločanja spremenljivk iz modela ohranili le tiste spremenljivke (trditve znotraj posameznega dejavnika), ki statistično značilno pojasnjujejo uspešnost podjetja s pomočjo strukturnega modela.

Hipotezo »Spremembe v okolju vplivajo na izbor strategije podjetja do kupcev, kar rezultira v uspešnosti podjetja. Podjetja, ki uporabljajo strategijo diferenciacije so uspešnejša kot tista, ki uporabljajo eno od ostalih ostale strategij (strategijo nizkih stroškov in privlačnih cen, strategijo osredinjenja, strategijo prehitevanja).« smo preverjali s pomočjo linearnih strukturnih 
modelov (SEM), pri čemer smo uporabili metodo analize poti (angl. path analysis). Preglednica 5 I prikazuje pomen spremenljivk v modelu SEM (slika 2)

V okviru strukturnih modelov smo uporabili dve faktorski analizi (preverjanje povezav med STRDIF in Q5 ter med DOBAVA in Q6), tri korelacijske analize (preverjanje povezav med $\mathrm{Q}_{2} \mathrm{C}$ in DOBAVA ter med seboj med napakami - e) ter tri regresijske analize, s katerimi smo preverili vplive med: STRDIF in ROA, EVA in BON; DOBAVA in STRDIF; $\mathrm{Q}_{2} \mathrm{C}$ in STRDIF (slika 2 in preglednica $5 \mathrm{I}$ ).

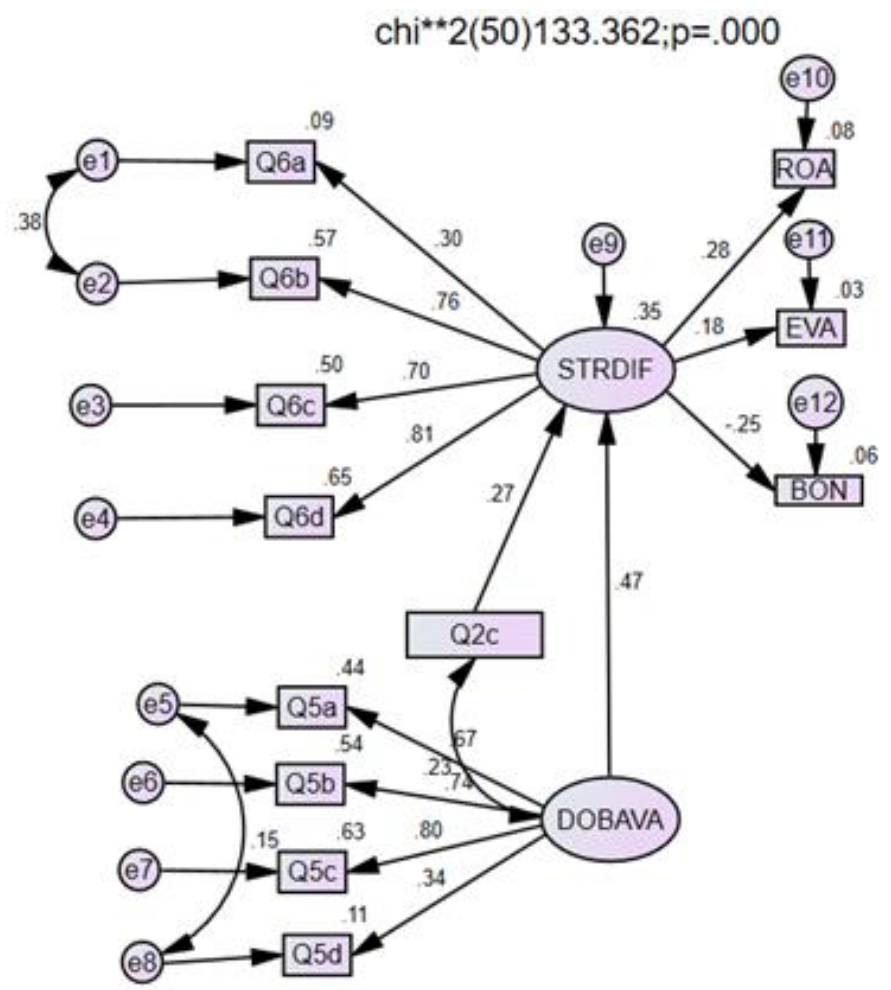

Slika 2: Model strukturnih enačb pri preverjanju hipoteze

Legenda: DOBAVA - dobavitelji; STRDIF - strategija diferenciacije, ROA - donosnost sredstev, EVA - ekonomska dodana vrednost, $\mathrm{BON}$ - bonitetna ocena, $\mathrm{p}$ - statistična značilnost 


\begin{tabular}{|c|c|}
\hline Qja & Naši glavni dobavitelji veljajo za vodilne na svojem področju poslovanja. \\
\hline $\mathrm{Q}_{5} \mathrm{~b}$ & S svojimi glavnimi dobavitelji vzpostavljamo dolgoročna strateška partnerstva. \\
\hline $\mathrm{Q}_{5 \mathrm{C}}$ & Naši glavni dobavitelji se hitro prilagajajo spremembam v panogi. \\
\hline $\mathrm{Q}_{5} \mathrm{~d}$ & $\begin{array}{l}\text { Konkurenčnost naših izdelkov/storitev je odvisna predvsem od inovativnosti } \\
\text { naših dobaviteljev. }\end{array}$ \\
\hline Q6a & $\begin{array}{l}\text { Naši izdelki/storitve so bistveno drugačni od našega glavnega tekmeca v } \\
\text { panogi. }\end{array}$ \\
\hline Q6b & Pri trženju smo inovativnejši kot naš glavni tekmec v panogi. \\
\hline Q6c & Stremimo k prepoznavnosti lastne blagovne znamke. \\
\hline Q6d & Več vlagamo v marketinško komuniciranje kot naš glavni tekmec v panogi. \\
\hline$Q_{2 C}$ & Na nas se obračajo povsem novi kupci, s katerimi še nismo sodelovali. \\
\hline
\end{tabular}

Podatek ROA smo pridobili iz javno dostopnih baz (GVIN) za zadnjih pet let. $V$ analizi smo upoštevali petletno povprečje. Podatek BON smo pridobili iz javno dostopnih baz (GVIN) za zadnja štiri leta. V analizi smo za podatek o BON tako upoštevali štiriletno povprečje. Spremenljivka BON je v osnovi opisna spremenljivka, ki smo ji za namen analize priredili rang (številčne vrednosti).

Slika 2 prikazuje moč povezav s Pearsonovim koeficientom (min. o, max. I). Višje vrednosti koeficientov kažejo na močnejšo povezavo (korelacija, regresija). Pri faktorski analizi moč povezav kaže beta vrednost. Višja kot je slednja, močnejši je vpliv, relativno v primerjavi z drugimi vplivi. Pozitivne vrednosti kažejo istosmerno povezavo, negativne vrednosti obratno povezavo.

Spremembe v okolju smo merili s štirimi skupinami trditev za pod-

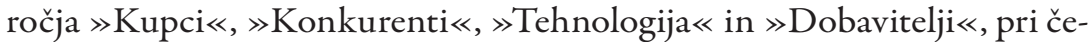
mer v končni analizi ostane le še sklop trditev (Q $5 a, b, c, d)$, ki se je nanašal na dobavitelje (DOBAVA) in eno izmed trditev $\left(\mathrm{Q}_{2} \mathrm{c}\right)$ za področje $\gg$ Kupci«. Uporabo strategije diferenciacije (STRDIF) smo merili s trditvami (Q6abcd).

Diagnostika strukturnega modela za model kot celoto ne poda idealnih vrednosti parametrov modela (preglednica 52). Dosegli smo najboljši približek na danem vzorcu, do katerega nam je uspelo priti z iterativnim postopkom izboljšav. Celoten izpis obdelave podatkov s strukturnim modelom za hipotezo podajamo v prilogi 5 . 


\begin{tabular}{|c|c|c|}
\hline Parameter & $\begin{array}{l}\text { Priporočene vrednosti } \\
\text { (Bentler in Bonett 1980) }\end{array}$ & $\begin{array}{l}\text { Dejanske vrednosti modela v naši } \\
\text { raziskavi }\end{array}$ \\
\hline $\begin{array}{l}\text { Bentler-Bonettov indeks ali normi- } \\
\text { ran indeks prileganja modela (NFI) }\end{array}$ & $\begin{array}{l}\text { med } 0,90 \text { in } 0,95 \text { - mejna vrednost } \\
\text { nad o,95- dobro prileganje } \\
\text { pod 0,90 - slabo prileganje }\end{array}$ & 0,759- slabo prileganje \\
\hline RMSEA & $\begin{array}{l}\text { ০,০I - odlično prileganje } \\
\text { o,०5-dobro prileganje } \\
\text { o,०8- povprečno prileganje }\end{array}$ & o,IOI - blizu povprečnega prileganja \\
\hline $\begin{array}{l}\text { TLI je odvisen od povprečne jakos- } \\
\text { ti korelacij med podatki, pri čemer je } \\
\text { njegova vrednost v obratnem soraz- } \\
\text { merju z jakostjo korelacij. }\end{array}$ & nad 0,95 - idealna vrednost & 0,727 - rahlo pod idealno vrednostjo \\
\hline CFI & $\begin{array}{l}\text { Ko je CFI pod I, bo CFI višji od TLI. } \\
\text { CFI ni relevanten, če je RMSEA } \\
\text { izhodiščnega modela pod o,I5 } 8 \text {. }\end{array}$ & $\begin{array}{l}\text { CFI }=0,825 \\
\text { Ker je v našem primeru RMSEA = } \\
\text { o,IOI, dajemo pri oceni modela težo } \\
\text { NFI, RMSEA in TLI. }\end{array}$ \\
\hline
\end{tabular}

Naš model ne podaja idealnih vrednosti povezave med dejavnikom »Spremembe v okolju « in uspešnostjo podjetja, kar lahko utemeljimo $s$ tem, da (I) je naš model relativno kompleksen, saj smo zajeli relativno veliko število povezav in vplivov; (2) velikost vzorca in odgovori, ki so jih podali anketiranci, vplivajo na rezultate modela. Ocenjujemo, da bi večji vzorec lahko pripomogel $k$ temu, da bi model dosegel optimalnejše vrednosti in bi tako tudi pridobil na posploševanju rezultatov. Zaradi velikosti ekonomije v Sloveniji in s tem števila podjetij se to odraža tudi na vzorcu. (3) Merski instrument se je na področju merjenja zunanjih vplivov okolja podjetja na uspešnost pri nas izkazal za šibkega. To se je zgodilo kljub temu, da smo izhajali iz predhodnih raziskav in uporabe merskega instrumenta, ki so ga uporabili drugi raziskovalci v svojih raziskavah (Jaworski in Kohli 1993; Li in Calantone 1998; Danneels in Sethi 2003; Strecker 2009). Odstopanje pri nas lahko utemeljimo z manjšo velikostjo vzorca pri podobni odzivnosti anketirancev. Ocenjujemo, da bi veljavnost modela lahko izboljšali s tem, ko bi optimizirali število povezav v njem (vključili bi manjšs število vplivov) in povečali vzorec.

\section{Povzetek ugotovitev preverjanja zastavljene hipoteze}

$\mathrm{Na}$ podlagi rezultatov analiz tako lahko potrdimo hipotezo, in sicer da spremembe v okolju vplivajo na izbor strategije podjetja do kupcev, kar rezultira v uspešnosti podjetja. Podjetja, ki uporabljajo strategijo diferenciacije, so uspešnejša kot tista, ki uporabljajo eno od ostalih strategij (stra- 
tegijo nizkih stroškov in privlačnih cen, strategijo osredinjenja, strategijo prehitevanja) (preglednica 53).

Preglednica 53: Povzetek ugotovitev preverjanja hipoteze

\begin{tabular}{ccccc} 
Analiza & $\begin{array}{c}\text { Statistična } \\
\text { znaćilnost } \\
\text { DA/NE }\end{array}$ & $\begin{array}{c}\text { Potrditev hipoteze } \\
\text { DA/NE }\end{array}$ & Ugotovitev & Vrsta vpliva \\
Strukturni model & DA & DA & Je potriena. & $\begin{array}{c}\text { Strategija diferencia- } \\
\text { cije pozitivno vpli- } \\
\text { va na ROA, EVA in } \\
\text { BON. }\end{array}$ \\
\hline
\end{tabular}

Uspelo nam je dokazati, da so podjetja, ki uporabljajo strategijo diferenciacije, uspešnejša kot tista, ki uporabljajo eno od ostalih ostale strategij. Rezultati kažejo, da ima strategija diferenciacije pozitiven učinek na ROA in EVA ter negativen na BON. Slednji je pričakovan, saj nižja vrednost $\mathrm{BON} v$ našem primeru pomeni višjo bonitetno oceno in $s$ tem višjo uspešnost. Dejansko to pomeni pozitiven (ugoden) vpliv. Pri pretvorbi opisnih bonitetnih ocen podjetij v številčne vrednosti smo namreč uporabili lestvico, na kateri smo najboljšo bonitetno oceno točkovali z najmanjšim in najslabšo z največjim številom točk. Majhno število BON tako pomeni visoko bonitetno oceno, kar pomeni višjo uspešnost. Na podlagi empirične analize s strukturnimi modeli za hipotezo lahko sklenemo, da le strategija diferenciacije vpliva na vidike uspešnosti podjetij.

Strategija diferenciacije pozitivno vpliva tako na ROA kot EVA in BON. Ugotavljamo, da na strategijo diferenciacije, ki je ena izmed strategij podjetja do kupcev, tudi vplivajo kupci, kar smo zaznali prek trditve Q2c, ki se glasi »Na nas se obračajo povsem novi kupci, s katerimi še nismo sodelovali «. Prav tako smo prek trditev (Qsa, b, c, d) ugotovili, da na strategijo diferenciacije vplivajo dobavitelji. Na strani dobaviteljev smo kot najvplivnejšo zaznali trditev $Q_{5 c}$, ki se glasi »Naši glavni dobavitelji se hitro prilagajajo spremembam $\mathrm{v}$ panogi $\ll$. 



\section{Sklep}

V sklepnem delu predstavljamo zaključno poročilo o doseganju ciljev raziskave ter implikacije za delo managerjev v praksi.

\section{Poročilo o doseganju ciljev raziskave}

Prvi cilj je bil podrobno preučiti literaturo in vire na področju vplivov okolja na podjetja ter strategij podjetja in njihovem vplivu na uspešnost poslovanja. Naredili smo sistematičen pregled bibliografskih enot domače in tuje strokovne literature za zadnjih trideset let (vključno z objavami $\mathrm{v}$ letu 2018), kjer smo sledili javno dostopnim znanstvenim bazam podatkov (Cobiss, Google Schoolar, Emerald, Ebsco). Spoznanja smo vključili $\mathrm{v}$ teoretični del raziskave. Še zlasti smo bili pozorni na to, da smo citirali najnovejše vire in literaturo iz leta 20r8. Ta cilj smo dosegli.

Drugi cilj raziskave je bil zasnovati in preveriti izvirni model o vplivu sprememb v zunanjem okolju podjetja na strategijo podjetja do kupcev in vplivu na uspešnost podjetij. Ta cilj smo dosegli. Model nam omogoča nadaljnje raziskave, poglobljene študije v Sloveniji ali primerljivih ekonomijah ter s tem odpira možnosti za doseganje novih ciljev, kar predstavljamo kot možnosti za nadaljnje raziskovanje.

Tretji cilj je bila izvedba empirične raziskave na populaciji MSP v Republiki Sloveniji. Pridobili smo javno dostopno bazo teh podjetij. Vzorčni okvir je predstavljalo 3.007 podjetij. Dosegli smo velikost vzorca I63, kar predstavlja $5,4 \%$ odzivnosti in je primerljivo $\mathrm{z}$ odzivnostjo $\mathrm{s}$ podobnimi študijami v svetu na tem področju. Ta cilj smo dosegli. 
Četrti cilj je bil razviti predloge na področju strategij podjetja do kupcev za večjo uspešnost podjetij. Na podlagi rezultatov raziskave smo razvili implikacije za delo v praksi, ki jih predstavljamo v nadaljevanju. Ta cilj smo dosegli.

\section{Implikacije za večjo uspešnost podjetij v praksi}

Na podlagi zastavljenega modela povezav (slika I) in rezultatov izvedenih analiz, predstavljenih v empiričnem delu raziskave, predlagamo naslednje implikacije za uspešnost podjetij. Implikacije podajamo na podlagi spoznanj in rezultatov raziskave na področju: (I) sprememb v okolju, (2) strategije podjetja do kupcev .

Ena izmed ključnih sposobnosti uspešnih podjetij je, da spremembe v okolju sprožajo, prav tako pa je ključno, da se podjetje nanje primerno odziva. $\mathrm{V}$ raziskavi smo potrdili, da spremembe v okolju vplivajo na izbor strategije podjetja do kupcev, kar rezultira v uspešnosti podjetja. Rezultati modeliranja z linearnimi strukturnimi modeli kažejo, da imajo spremembe v okolju na področju dobaviteljev in kupcev statistično največji vpliv na izbor strategije diferenciacije. Prav tako smo potrdili, da ima strategija diferenciacije pozitiven vpliv na uspešnost podjetja. Na podlagi tega najprej podajamo implikacije za podjetja na področju dobaviteljev ter kupcev, ki jih v nadaljevanju povezujemo z izborom strategije diferenciacije in uspešnostjo podjetij.

Podjetja bodo uspešnejša, če bodo: (I) sodelovala z dobavitelji, ki na svojem področju veljajo za vodilne (vodje v panogi); (2) z dobavitelji vzpostavljala dolgoročna strateška partnerstva za doseganje vzajemnih koristi; (3) njegovi dobavitelji imeli sposobnost hitrega prilagajanja na spremembe v panogi; (4) konkurenčnost izdelkov/storitev dosegala s pomočjo inovativnosti svojih dobaviteljev. Takšno sodelovanje podjetij z dobavitelji ima statistično značilen vpliv na izbor strategije podjetja do kupcev - diferenciacijo in vodi v večjo uspešnost podjetja.

Podjetja bodo uspešnejša, če bodo v poslovanje vključevala vidik kupca. Statistično najznačilnejši vpliv na izbor strategije podjetja do kupcev - strategijo diferenciacije - smo ugotovili v primerih, ko podjetje sodeluje z novimi kupci, s katerimi do zdaj še ni sodelovalo. Več ima podjetje takšnih kupcev, verjetneje je, da bo uporabljalo strategijo diferenciacije. Podjetja, ki uporabljajo strategijo diferenciacije, so uspešnejša kot tista, ki te strategije ne uporabljajo.

Če bo podjetje sodelovalo z dobavitelji na način, kot je opisan zgoraj, in bo podjetje sodelovalo z novimi kupci, s katerimi prej še ni sodelovalo, bo vplivalo na to, da bo podjetje do kupcev izbralo strategijo dife- 
renciacije. Strategija diferenciacije pozitivno vpliva na uspešnost podjetja (EVA in BON). Njena uporaba pomeni, da: (I) podjetje razvija izdelke/ storitve, ki se čim bolj razlikujejo od izdelkov/storitev glavnega tekmeca v panogi; (2) je podjetje pri trženju izdelkov/storitev inovativnejše kot glavni tekmec v panogi; (3) podjetje razvije lastno prepoznavno blagovno znamko; (4) podjetje $\mathrm{v}$ marketinško komuniciranje vlaga več kot glavni tekmec $v$ panogi. 



\section{Priloga I: Anketni vprašalnik}

\section{IZBRANI DEJAVNIKI ZUNANJEGA OKOLJA IN PODJETJE}

\section{I.I Spremembe v okolju}

\section{Kupci}

Navodilo: Za vsako trditev označite en ustrezen odgovor. Odgovor naj se nanaša na podjetje kot celoto za vse izdelke/storitve za časovno obdobje zadnjih 5 let (2012-2016).

\begin{tabular}{lllllll}
\hline & \multicolumn{5}{c}{ Ocena } \\
\cline { 2 - 6 } Trditev: & \multicolumn{4}{c}{$\begin{array}{c}\text { I- } \\
\text { Nikakor ne drži. }\end{array}$} & \multicolumn{2}{c}{ Zelo drži. } \\
\hline Kupciv naši panogi nenehno zahtevajo nove izdelke/storitve. & I & 2 & 3 & 4 & 5 & 6 \\
\hline Zahteve kupcev o izdelkih/storitvah se s časom zelo malo spreminjajo. & I & 2 & 3 & 4 & 5 & 6 \\
\hline Na nas se obračajo povsem novi kupci, s katerimi še nismo sodelovali. & I & 2 & 3 & 4 & 5 & 6 \\
\hline Struktura naših kupcev se s časom zelo malo spreminja. & I & 2 & 3 & 4 & 5 & 6 \\
\hline
\end{tabular}

\section{Konkurenti}

\begin{tabular}{|c|c|c|c|c|c|c|}
\hline \multirow{3}{*}{$\begin{array}{l}\text { Trditev: } \\
\text { V našo panogo ves čas vstopajo novi konkurenti. }\end{array}$} & \multicolumn{6}{|c|}{ Ocena } \\
\hline & \multicolumn{3}{|c|}{$\begin{array}{c}\text { I- } \\
\text { Nikakor ne drži. }\end{array}$} & \multicolumn{3}{|c|}{$\begin{array}{c}6- \\
\text { Zelo drži. }\end{array}$} \\
\hline & I & 2 & 3 & 4 & 5 & 6 \\
\hline Konkurenti v naši panogi pogosto spreminjajo svojo strategijo. & I & 2 & 3 & 4 & 5 & 6 \\
\hline Tržni deleži med konkurenti v naši panogi se s časom zelo spreminjajo. & I & 2 & 3 & 4 & 5 & 6 \\
\hline Naš glavni tekmec v panogi se hitreje prilagaja na spremembe kot mi. & I & 2 & 3 & 4 & 5 & 6 \\
\hline
\end{tabular}




\section{Tehnologija}

Trditev:

\begin{tabular}{cc}
\multicolumn{2}{c}{ Ocena } \\
\hline I - & $6-$ \\
Nikakor ne drži. & Zelo drži.
\end{tabular}

Tehnološke spremembe, ki se dogajajo v naši panogi, so zelo velike.

Tehnološke spremembe se v naši panogi dogajajo zelo hitro.

Tehnološke spremembe nam omogočajo veliko novih priložnosti za rast našega podjetja.

Tehnološki razvoj za nadaljnja 2-3 leta je v naši panogi zelo težko napovedati.

\section{Dobavitelji}

\begin{tabular}{|c|c|c|c|c|c|c|}
\hline \multirow{3}{*}{$\begin{array}{l}\text { Trditev: } \\
\text { Naši glavni dobavitelji veljajo za vodilne na svojem področju poslovanja. }\end{array}$} & \multicolumn{6}{|c|}{ Ocena } \\
\hline & \multicolumn{3}{|c|}{$\begin{array}{l}\text { I- } \\
\text { Nikakor ne drži. }\end{array}$} & \multicolumn{3}{|c|}{$\begin{array}{c}6- \\
\text { Zelo drži. }\end{array}$} \\
\hline & I & 2 & 3 & 4 & 5 & 6 \\
\hline $\begin{array}{l}\text { S svojimi glavnimi dobavitelji vzpostavljamo dolgoročna strateška } \\
\text { partnerstva. }\end{array}$ & I & 2 & 3 & 4 & 5 & 6 \\
\hline Naši glavni dobavitelji se hitro prilagajajo spremembam v panogi. & I & 2 & 3 & 4 & 5 & 6 \\
\hline $\begin{array}{l}\text { Konkurenčnost naših izdelkov/storitev je odvisna predvsem od } \\
\text { inovativnosti naših dobaviteljev. }\end{array}$ & I & 2 & 3 & 4 & ) & 6 \\
\hline
\end{tabular}

\section{I.2 Strategija podjetja do kupcev}

\section{Strategija diferenciacije}

Razlaga: Tekmec v vaši panogi je podobno podjetje, kot je vaše, ki za vami ne zaostaja ali prednjači mnogo, z njim se spopadate in poskušate osvojiti ali ohraniti vodstvo pred njim.

\begin{tabular}{|c|c|c|c|c|c|c|}
\hline \multirow[t]{2}{*}{ Trditev: } & \multicolumn{6}{|c|}{ Ocena } \\
\hline & \multicolumn{3}{|c|}{$\begin{array}{l}\text { I- } \\
\text { Nikakor ne drži. }\end{array}$} & \multicolumn{3}{|c|}{$\begin{array}{c}6- \\
\text { Zelo drži. }\end{array}$} \\
\hline $\begin{array}{l}\text { Naši izdelki/storitve so bistveno drugačni od našega glavnega } \\
\text { tekmeca v panogi. }\end{array}$ & I & 2 & 3 & 4 & 5 & 6 \\
\hline Pri trženju smo inovativnejši kot naš glavni tekmec v panogi. & I & 2 & 3 & 4 & 5 & 6 \\
\hline Stremimo k prepoznavnosti lastne blagovne znamke. & 1 & 2 & 3 & 4 & 5 & 6 \\
\hline $\begin{array}{l}\text { Več vlagamo v marketinško komuniciranje kot naš glavni tekmec v } \\
\text { panogi. }\end{array}$ & I & 2 & 3 & 4 & 5 & 6 \\
\hline
\end{tabular}




\section{Strateg nizkih stroškov in privlačnih cen}

\begin{tabular}{|c|c|c|c|c|c|c|}
\hline \multirow{3}{*}{$\begin{array}{l}\text { Trditev: } \\
\begin{array}{l}\text { V podjetju smo pri izvajanju poslovnih aktivnosti visoko učinkoviti } \\
\text { (produktivni). }\end{array}\end{array}$} & \multicolumn{6}{|c|}{ Ocena } \\
\hline & \multicolumn{3}{|c|}{ Nikakor ne drži. } & \multicolumn{3}{|c|}{$\begin{array}{c}6- \\
\text { Zelo drži. }\end{array}$} \\
\hline & I & 2 & 3 & 4 & 5 & 6 \\
\hline Na trgu konkuriramo z nizkimi cenami naših izdelkov/storitev. & I & 2 & 3 & 4 & 5 & 6 \\
\hline $\begin{array}{l}\text { V procesih podjetja nenehno poudarjamo zniževanje vseh vrst stroškov } \\
\text { poslovanja. }\end{array}$ & I & 2 & 3 & 4 & 5 & 6 \\
\hline $\begin{array}{l}\text { Pri iskanju stroškovno najugodnejših virov (materialov, energije, znanja } \\
\text { ipd.) na trgu smo zelo uspešni. }\end{array}$ & I & 2 & 3 & 4 & 5 & 6 \\
\hline
\end{tabular}

\section{Strategija osredinjenja}

\begin{tabular}{lcccccc}
\hline & \multicolumn{5}{c}{ Ocena } \\
\cline { 2 - 6 } Trditev: & \multicolumn{3}{c}{ Nikakor ne drži. } & \multicolumn{3}{c}{ Zelo drži. } \\
\hline Z našimi izdelki/storitvami ciljamo na ozek segment kupcev. & I & 2 & 3 & 4 & 5 & 6 \\
\hline Na trg ponujamo ožji nabor izdelkov/storitev kot naša konkurenca. & I & 2 & 3 & 4 & 5 & 6 \\
\hline Na trg ponujamo izdelke/storitve v ozkem cenovnem segmentu. & I & 2 & 3 & 4 & 5 & 6 \\
\hline Na trg ponujamo specialne/nišne izdelke/storitve. & I & 2 & 3 & 4 & 5 & 6 \\
\hline
\end{tabular}

\section{Strategija prehitevanja}

\begin{tabular}{lcccccc}
\hline & \multicolumn{5}{c}{ Ocena } \\
\cline { 2 - 7 } Trditev: & \multicolumn{3}{c}{$\begin{array}{c}\text { N I - } \\
\text { Nikakor ne drži. }\end{array}$} & \multicolumn{2}{c}{ Zelo drži. } \\
\hline Nove potrebe trga zaznamo hitreje kot naš glavni tekmec. & I & 2 & 3 & 4 & 5 & 6 \\
\hline Nove izdelke/storitve na trg uvajamo hitreje kot naš glavni tekmec. & I & 2 & 3 & 4 & 5 & 6 \\
\hline $\begin{array}{l}\text { Pri uvajanju sprememb v svoje poslovanje smo hitrejši kot naš glavni } \\
\text { tekmec. }\end{array}$ & I & 2 & 3 & 4 & 5 & 6 \\
\hline Spremembe v panogi sprožamo hitreje kot naš glavni tekmec. & I & 2 & 3 & 4 & 5 & 6 \\
\hline
\end{tabular}




\section{PODATKI O PODJETJU IN ANKETIRANCU}

Vljudno Vas prosim, da izpolnite tudi zadnje poglavje tega vprašalnika (demografski podatki in podatki o podjetju), saj so ključni za analizo odgovorov in uspešnost raziskave.

\section{I Uspešnost podjetja glede na glavnega tekmeca v panogi}

Razlaga: Tekmec v vaši panogi je podobno podjetje, kot je vaše, ki za vami ne zaostaja ali prednjači mnogo, z njim se spopadate in poskušate osvojiti ali ohraniti vodstvo pred njim.

Navodilo: Označite en ustrezen odgovor.

\begin{tabular}{llcccc}
\hline \multirow{2}{*}{ Trditev: } & \multicolumn{3}{c}{ Ocena } \\
\cline { 2 - 5 } & $\begin{array}{r}\text { I- Bistveno } \\
\text { manj uspešno. }\end{array}$ & $\begin{array}{c}6 \text { - Bistveno } \\
\text { uspešneje. }\end{array}$ \\
\hline $\begin{array}{l}\text { Glede na našega glavnega tekmeca v panogi ocenjujem, da je naše } \\
\text { podjetje v zadnjih } 5 \text { letih }(2011-2015):\end{array}$ & I & 2 & 3 & 4 & 5
\end{tabular}

\subsection{Panoga, v kateri posluje podjetje (v letu 2015)}

Navodilo: Ustrezno označite en ustrezen odgovor oz. po potrebi dopolnite.
a) Kmetijstvo in lov, gozdarstvo, ribištvo
b) Rudarstvo
c) Predelovalne dejavnosti
d) Oskrba z električno energijo, plinom in paro
e) Oskrba z električno energijo
f) Oskrba z vodo, ravnanje z odplakami in odpadki, saniranje okolja
g) Gradbeništvo
h) Trgovina, vzdrževanje in popravila motornih vozil
i) Promet in skladiščenje
j) Gostinstvo
k) Informacijske in komunikacijske dejavnosti
1) Finančne in zavarovalniške dejavnosti
m) Poslovanje z nepremičninami
n) Strokovne, znanstvene in tehnične dejavnosti
o) Druge raznovrstne poslovne dejavnosti
p) Izobraževanje
q) Zdravstvo in socialno varstvo
r) Drugo (dopolnite): 


\subsection{Povprečno število zaposlenih v podjetju v letu 2016}

Navodilo: Označite en ustrezen odgovor.
a) od ro do 49 (majhno podjetje)
b) od so do 249 (srednje podjetje)

2.4 Statusna oblika podjetja v letu 2016

Navodilo: Označite en ustrezen odgovor oz. po potrebi dopolnite.
a) samostojni podjetnik (s. p.)
b) družba z omejeno odgovornostjo (d. o. o.)
c) družba z neomejeno odgovornostjo (d. n. o.)
d) delniška družba (d. d.)
e) druga oblika podjetja pridobitne dejavnosti (dopolnite- te):

\subsection{Dosežena najvišja stopnja izobrazbe anketiranca}

Navodilo: Označite en ustrezen odgovor.
a) poklicna ali srednješolska
b) dodiplomska višješolska, visokošolska ali univerzitetna (VŠ, VS ali bolonjska UN)
c) dodiplomska univerzitetna (stari program) ali strokovni magisterij (bolonjski)
d) znanstveni magisterij (stari program)
e) doktorat znanosti (prejšnji ali bolonjski)

\subsection{Trenutna funkcija anketiranca v podjetju}

Navodilo: Označite en ustrezen odgovor oz. po potrebi dopolnite.
a) generalni direktor
b) tehnični direktor
c) direktor ali vodja poslovne funkcije (enote, oddelka, sektor- ja)
d) skrbnik procesa
e) vodja projektov za izboljšave
f) član tima projektov za izboljšave
g) drugo (dopolnite): 


\subsection{Ime Vašega podjetja}

UTEMELJITEV: Ime podjetja potrebujemo, ker bomo iz javno dostopnih evidenc (AJPES) sami pridobili podatke o prihodkih podjetja in povprečnih vrednostih za zadnja leta, saj jih vi zdaj ne veste na pamet in teh podatkov zdaj tukaj ne morete pravilno navesti.

Uporabili bomo javno dostopne podatke (povprečne vrednosti za vsa podjetja v tej raziskavi skupaj, statistično). Ime Vašega podjetja in anketiranca bo ostalo anonimno in ne bo nikjer pisno omenjeno.

Vljudno Vas prosim, da spodaj vpišete ime podjetja.

Prosim, vpišite ime podjetja:

Pomembno: Ime Vašega podjetja je potrebno za uspešno izvedbo raziskave in bo ostalo anonimno.

Anonimnost zagotavljamo s tem, da bomo:

Podatke obdelali anonimno in ne bodo povezani z Vašim podjetjem ali anketirancem.

Rezultate bomo uporabili samo za raziskovalne namene, obdelali jih bomo skupno statistično, v povprečnih vrednostih za vse skupaj zbrane odgovore vseh podjetij, ki bodo sodelovala v tej raziskavi.

Vpišite Vaš e-mail naslov: (vpišite po želji), če želite, da Vam po končani raziskavi pošljemo rezultate raziskave.

Hvala za Vaš čas in sodelovanje. 


\section{Priloga 2: Opisna statistika za dejavnik »Spremembe v okolju«}

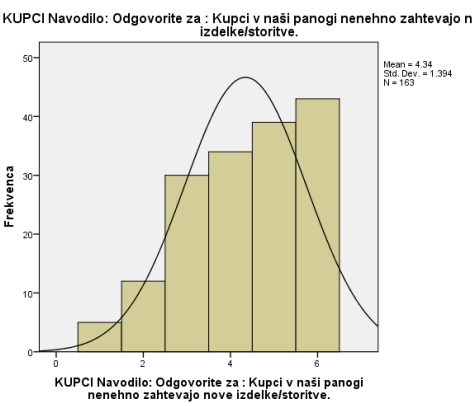

KUPCI Navodilo: Odgovorite za: Zahteve kupcev o izdelkih/storitvah se s časom

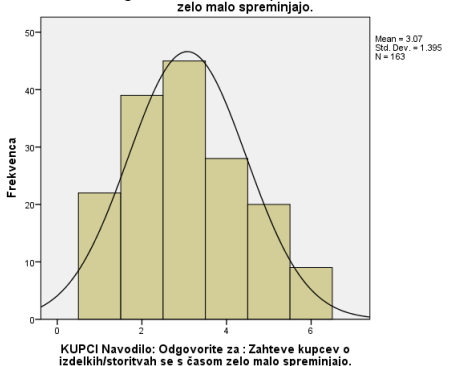

KONKURENTI Navodilo: Odgovorit: V našo panogo ves ćas vstopajo novi

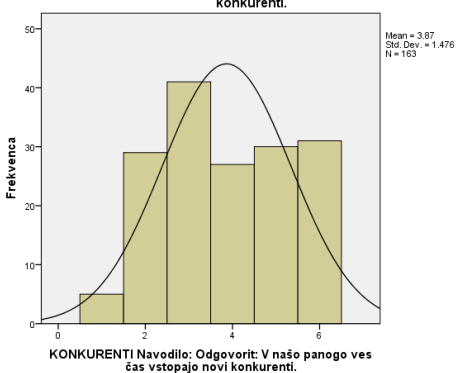

as vstopajo novi konkurenti.

KONKURENTI Navodilo: Odgovorit: Konkurenti v naši panogi pogosto
spreminjajo svojo strategijo.

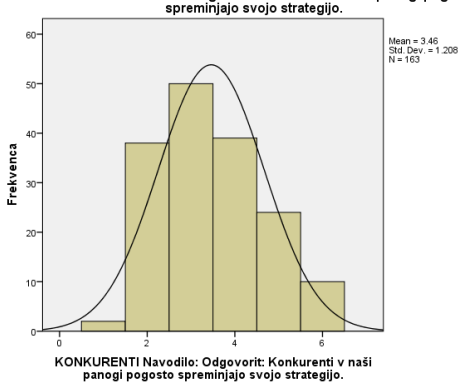




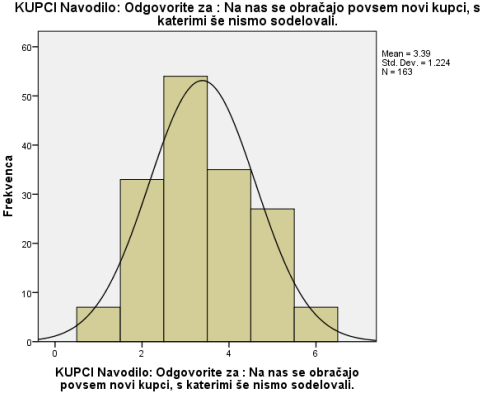

KUPCI Navodilo: Odgovorite za : Struktura naših kupcev se s časom zelo malo

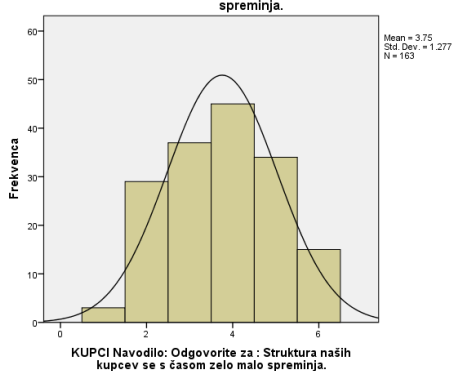

KONKURENTI Navodilo: Odgovorit: Tržni deleži med konkurenti v naši panogi se

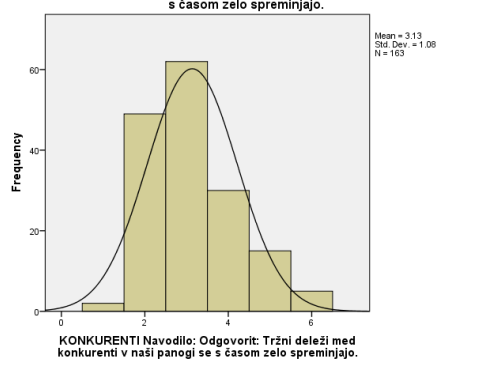

KONKURENTI Navodilo: Odgovorit: Nas̄ glavni tekmec v panogi se hitreje

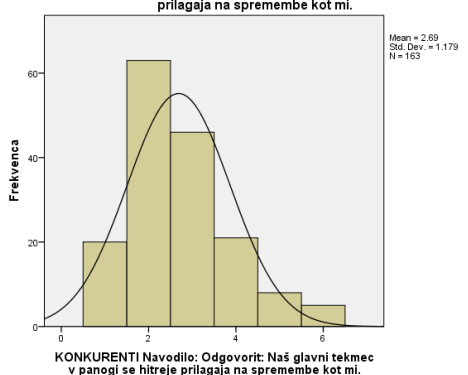

Spremembe v okolju: kupci (1. stolpec) in konkurenti (2. stolpec)

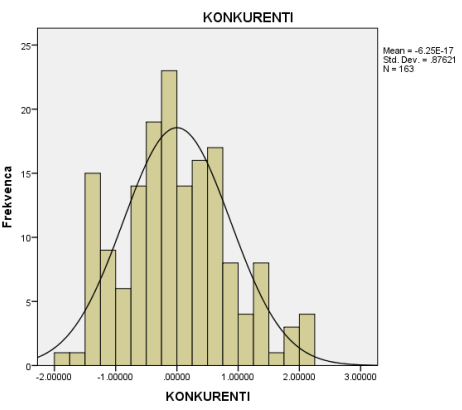

Spremembe v okolju: konkurenti 
Priloga 2: Opisna statistika za dejavnik »Spremembe v okolju «

TEHNOLOGIJA Navodilo: Odgovori: Tehnolos̄ke spremembe, ki se dogajajo v

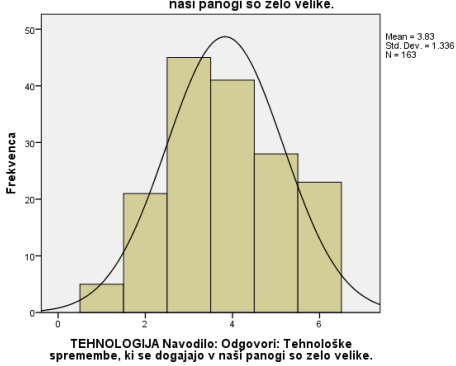

TEHNOLOGIJA Navodilo: Odgovori: Tehnološke spremembe se v nasii panogi

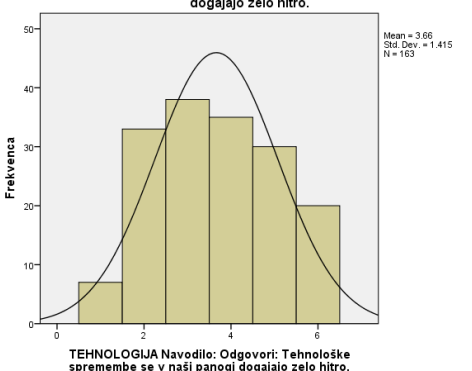

TEHNOLOGIJA Navodilo: Odgovori: Tehnološke spremembe nam omogočajo

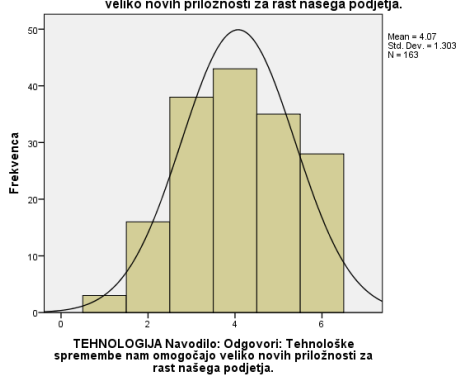

TEHNOLOGIJA Navodilo: Odgovori: Tehnološki razvoj za nadaljnja 2.3 leta je v

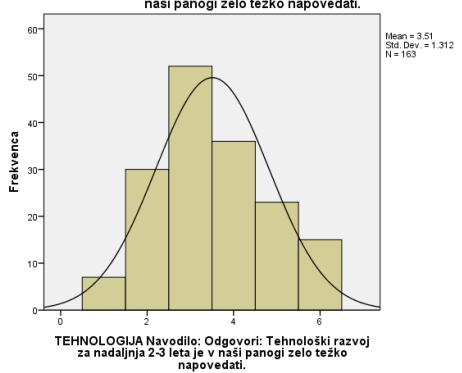

DOBAVITELJI Navodilo: Odgovori: Naši glavni dobavitelji veljajo za vodilne na
svojem podrocju poslovanja.

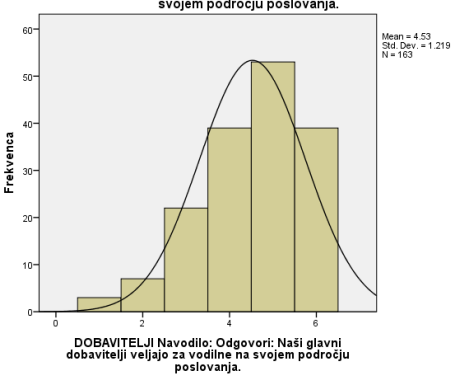

DOBAVITELJI Navodilo: Odgovori: $Z$ našimi glavnimi dobavitelji vzpostavljamo

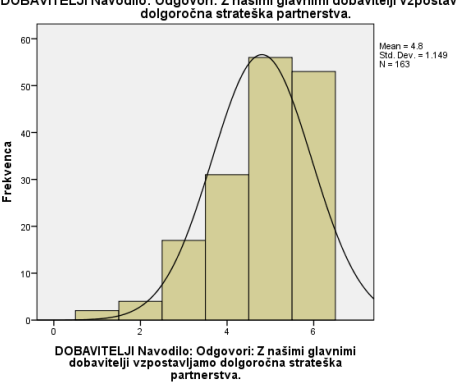

DOBAVITELJI Navodilo: Odgovori: Nas̄i glavni dobavitelji se hitro prilagajajo

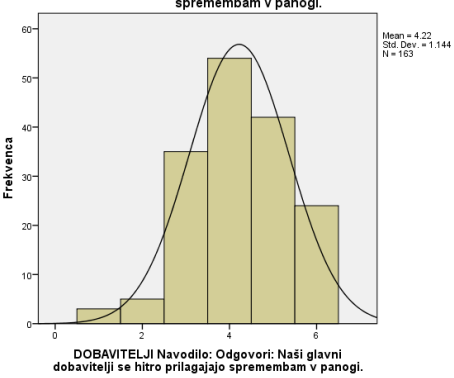

DOBAVITELJI Navodilo: Odgovori: Konkurenćnost naših izdelkov/storitev je

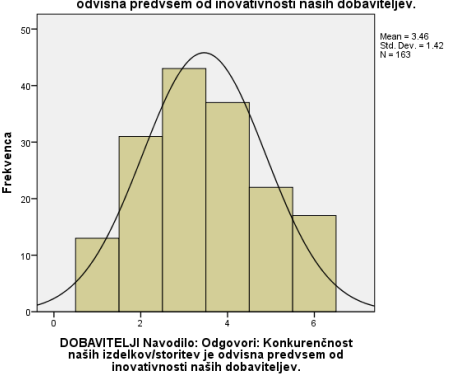

Spremembe v okolju: tehnologija (1. stolpec) in dobavitelji (2. stolpec) 



\section{Priloga 3: Opisna statistika za dejavnik »Strategija podjetja do kupcev«}

STRATEGIJA DIFERENCIRANJA Navo: Naši izdelkilstoritve so bistveno drugačni

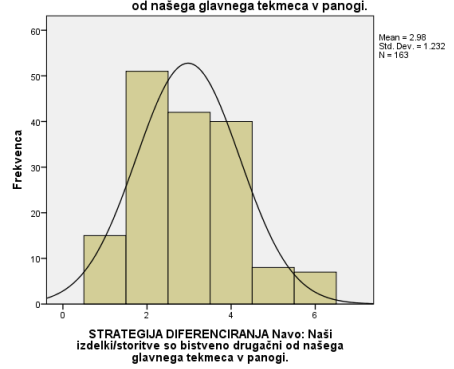

STRATEGIJA DIFERENCIRANJA Navo: Pri trženju smo bolj inovativni kot nas̄ glavni tekmec $\mathrm{v}$ panogi.
gla

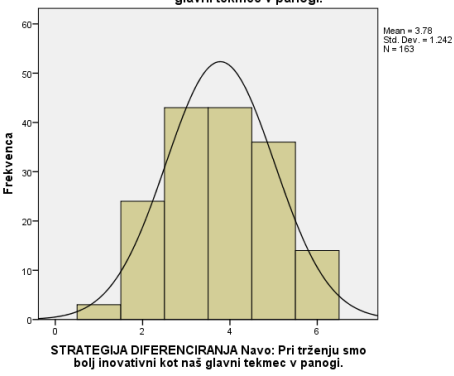

STRATEGIJA DIFERENCIRANJA Navo: Naši izdelki/storitve so bistveno drugačni

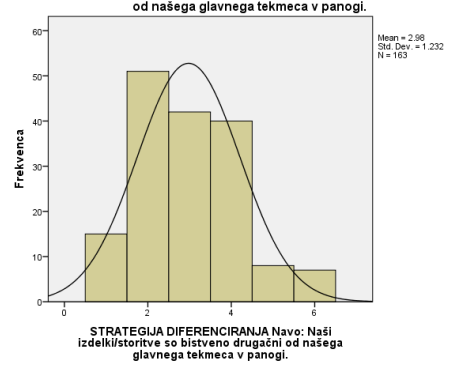

STRATEGIJA NIZKIH STROS̄KoV IN: Na trgu konkuriramo z nizkimi cenami naših

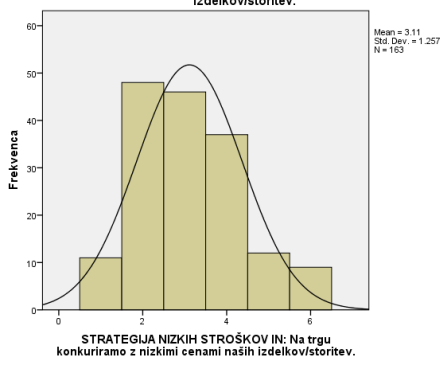




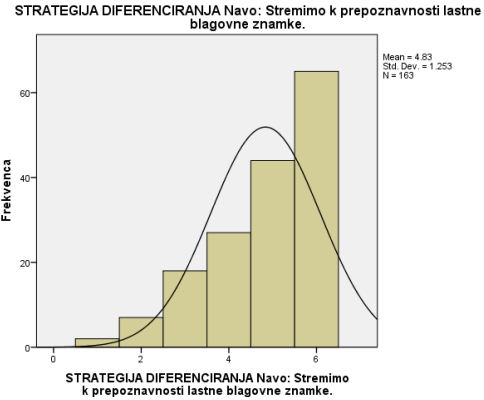

STRATEGIJA DIFERENCIRANJA Navo: Vec̄ vlagamo v marketins̄ko

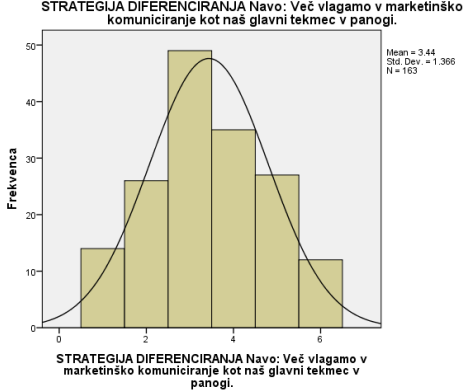

STRATEGIJA NIZKIH STROŠKOV IN: V procesih podjetja nenehno poudarjamo

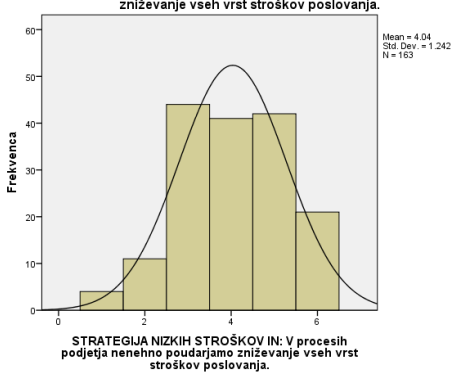

strośkov poslovanja.

STRATEGIJA NIZKIH STROŠKOV IN: Pri iskanju stroškovno najugodnejših virov

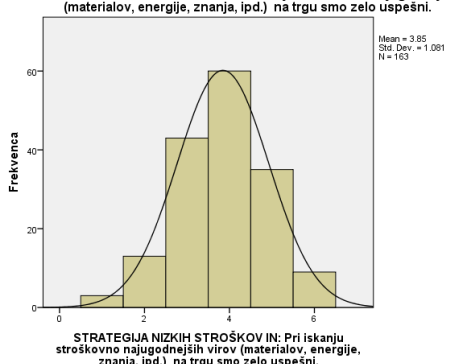

Strategija podjetja do kupcev: diferenciacija ( I. stolpec) in nizki stroški (2. stolpec) 
Priloga 3: Opisna statistika za dejavnik »Strategija podjetja do kupcev«
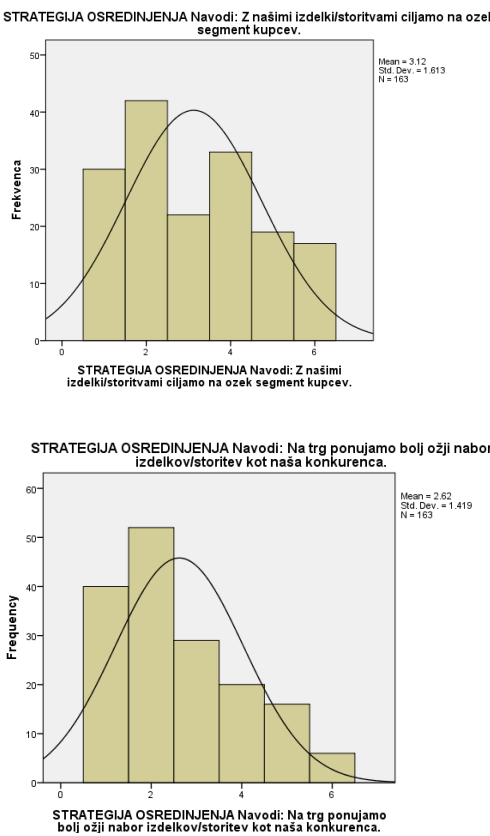

STRATEGIJA OSREDINJENJA Navodi: Na trg ponujamo izdelke/storitve $v$ ozkem

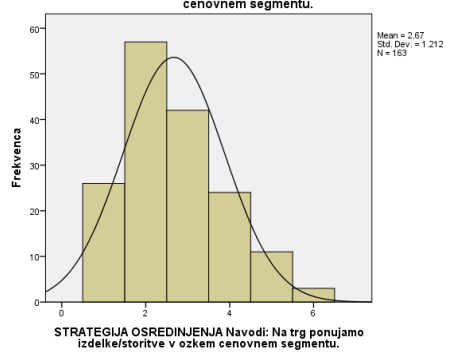

STRATEGIJA OSREDINJENJA Navodi: Na trg ponujamo specialne/nišne

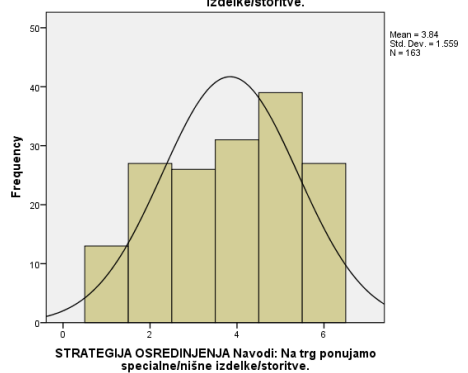

STRATEGIJA PREHITEVANJA Navodi: Nove potrebe trga zaznamo hitreje kot
naš glavni tekmec.

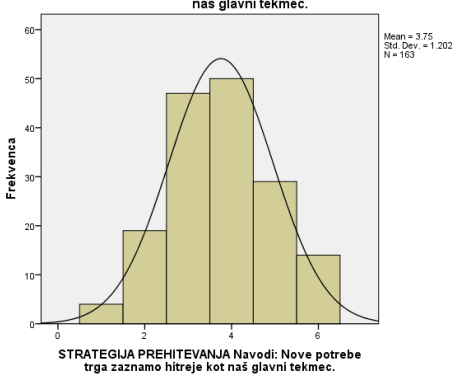

STRATEGIJA PREHITEVANJA Navodi: Nove izdelke/storitve na trg uvajamo

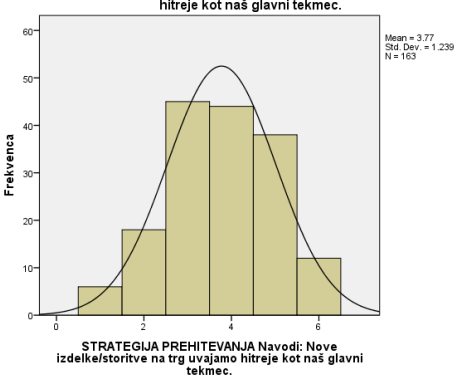

STRATEGIJA PREHITEVANJA Navodi: Pri uvajanju sprememb v naše poslovanje
smo hitrejśi naš glavni tekmec.

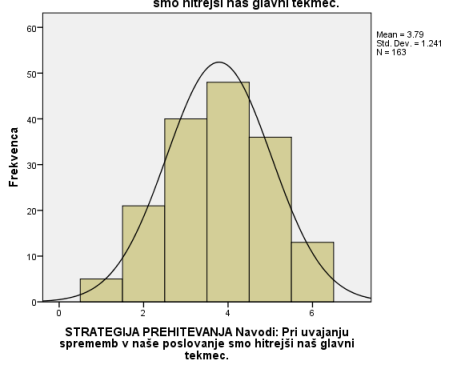

STRATEGIJA PREHITEVANJA Navodi: Spremembe v panogi sprożamo hitreje

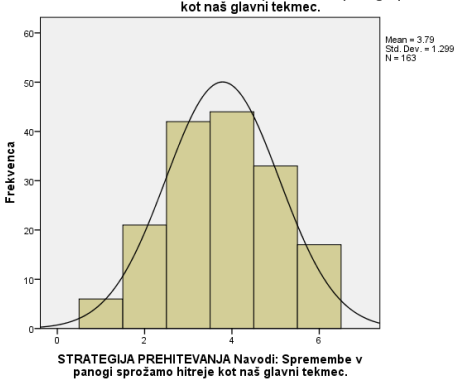

Strategija podjetja do kupcev: osredinjenja (I. stolpec) in prehitevanja (2. stolpec) 
SNOVANJE Navodilo: Odgovori na: Pri snovaniu sprememb temeljnega procesa

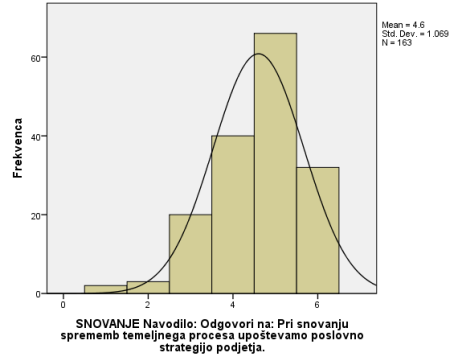

SNOVANJE Navodilo: Odgovori na: Pri snovanju sprememb temeljnega procesa

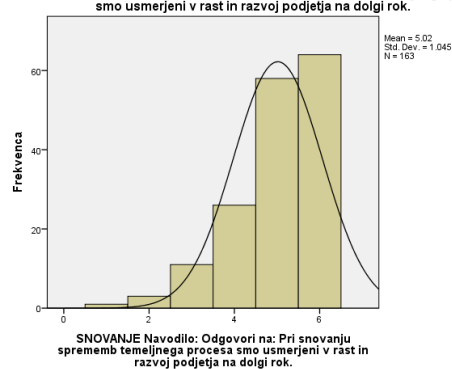

SNOVANJE Navodilo: Odgovori na: Pri snovanju sprememb temeljnega procesa

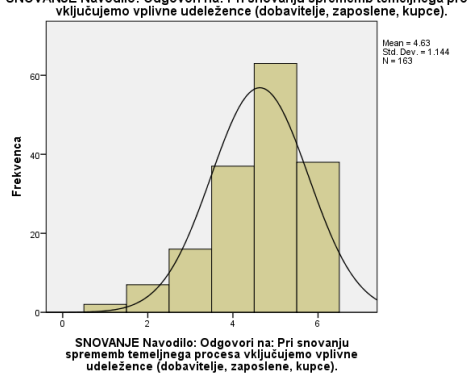

SNOVANJE Navodilo: Odgovori na: Pri snovanju sprememb temeljnega procesa

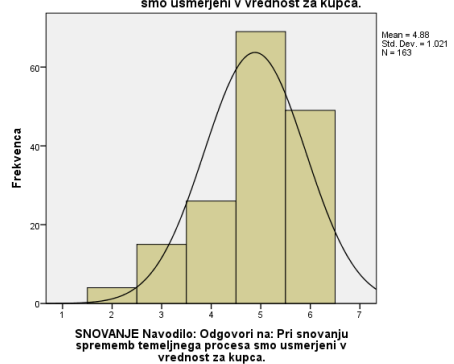

NAČRTOVANJE Navodilo: Odgovor: Pri nacritovanju sprememb temeljnega procesa je poudarek na uēinkovitosti (ëimmanjs̄i stroški dela in materiala

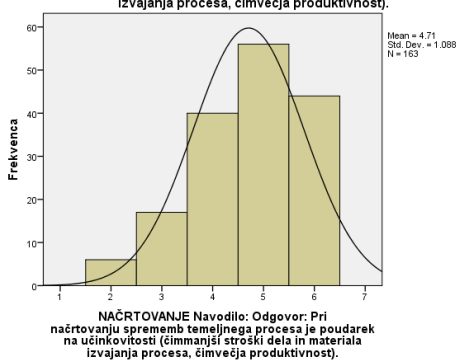

NAČRTOVANJE Navodilo: Odgovor: Pri naçrtovanju sprememb temeljnega

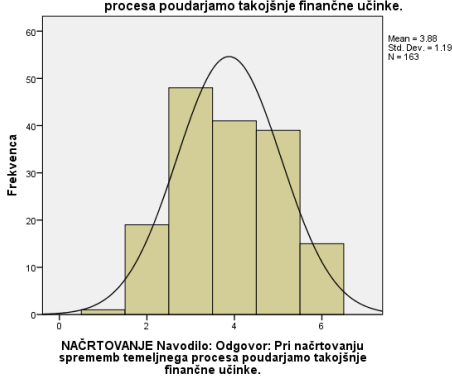

NAČRTOVANJE Navodilo: Odgovor: Načrtovanje sprememb temelinega procesa poteka od vrha navzdol (odlocitive vodstrativozij).
operativnih nivojih).

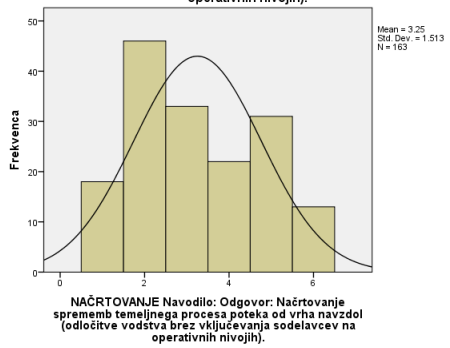

NAČRTOVANJE Navodilo: Odgovor: Načrtovanje sprememb temeljnega procesa
poteka izključno ob formalnih srečanjih (sestankih z vnaprej določenimi okviri).

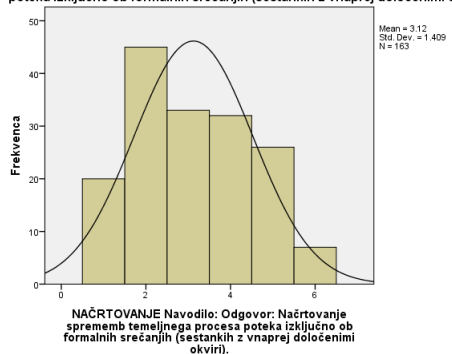




\section{Priloga 4: Opisna statistika za uspešnost podjetja}

\begin{tabular}{|c|c|c|c|c|c|}
\hline & \multicolumn{5}{|c|}{$\operatorname{ROA}(\%)$} \\
\hline & 2012 & 2013 & 2014 & 2015 & 2016 \\
\hline Povprečna vrednost & 4,82 & 4,78 & 6,63 & 6,82 & 6,63 \\
\hline Standardni odklon & 9,350 & 10,869 & $\mathrm{IO}, 38 \mathrm{I}$ & 9,089 & 7,786 \\
\hline Koeficient asimetričnosti & 3,085 & $-4,258$ & 4,206 & $\mathrm{I}, 98 \mathrm{I}$ & $\mathrm{I}, 8 \mathrm{I} 7$ \\
\hline Koeficient sploščenosti & 21,909 & 45,710 & 30,359 & 10,189 & 7,879 \\
\hline Minimum & $-23,10$ & $-95,56$ & $-12,51$ & $-28,64$ & $-15,27$ \\
\hline Maksimum & 75,98 & 41,69 & 93,07 & 59,10 & $5 \mathrm{I}, 86$ \\
\hline
\end{tabular}

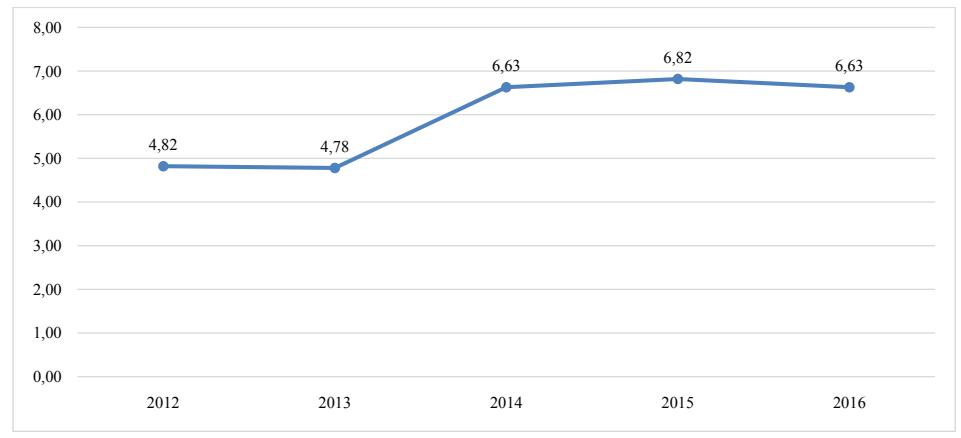

$(\mathrm{N}=163)$

Finančni kazalnik uspešnosti podjetij ROA ( 5 -letno povprečje) (GVIN 20I8b) 
Strategije in uspešnost podjetja

\begin{tabular}{|c|c|c|c|c|c|}
\hline & \multicolumn{5}{|c|}{$\operatorname{ROE}(\%)$} \\
\hline & 2012 & 2013 & 2014 & 2015 & 2016 \\
\hline Povprečna vrednost & $-8,53$ & 4,30 & 14,44 & 14,38 & 4,42 \\
\hline Standardni odklon & 245,963 & I4 1,021 & 31,136 & 24,380 & 120,410 \\
\hline Koeficient asimetričnosti & $-12,000$ & $-11,391$ & $-1,371$ & 0,914 & $-12,02 \mathrm{I}$ \\
\hline Koeficient sploščenosti & $\mathrm{I} 48,95 \mathrm{I}$ & 139,125 & 16,986 & 9,188 & 147,956 \\
\hline Minimum & $-3046,41$ & $-1716,47$ & $-190,53$ & $-95,50$ & $-1468,10$ \\
\hline Maksimum & 246,08 & 174,18 & 153,36 & 142,67 & $98, \circ 0$ \\
\hline
\end{tabular}

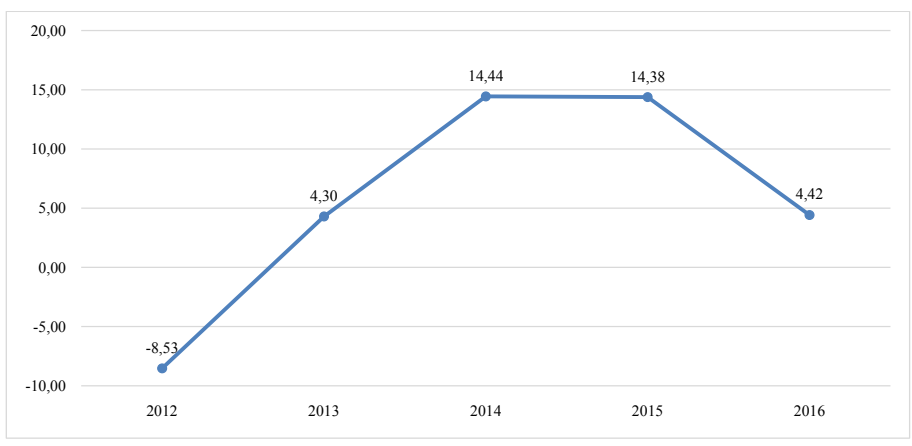

$(\mathrm{N}=163)$

Finančni kazalnik uspešnosti podjetij ROE ( 5 -letno povprečje) (GVIN 20 18b) 
Priloga 4: Opisna statistika za uspešnost podjetja

\begin{tabular}{|c|c|c|c|c|c|}
\hline & \multicolumn{5}{|c|}{ EVA (EUR) } \\
\hline & 2012 & 2013 & 2014 & 2015 & 2016 \\
\hline Povprečna vrednost & 40414,85 & 40874,57 & 41993,25 & 42443,83 & 43784,57 \\
\hline Standardni odklon & 22403,701 & 22750,668 & 24442,588 & 22349,648 & 24174,065 \\
\hline Koeficient asimetričnosti & $\mathrm{I}, 07 \mathrm{I}$ & 1,695 & 2,286 & 2,042 & 1,283 \\
\hline Koeficient sploščenosti & $\mathrm{I}, 98 \mathrm{I}$ & 5,032 & 7,601 & 6,217 & 4,940 \\
\hline Minimum & $-28563,00$ & $-12025,00$ & $-2357,00$ & 7,71 & $-47670,00$ \\
\hline Maksimum & 115124,00 & 155143,00 & 168712,00 & 155624,00 & 151601,00 \\
\hline
\end{tabular}

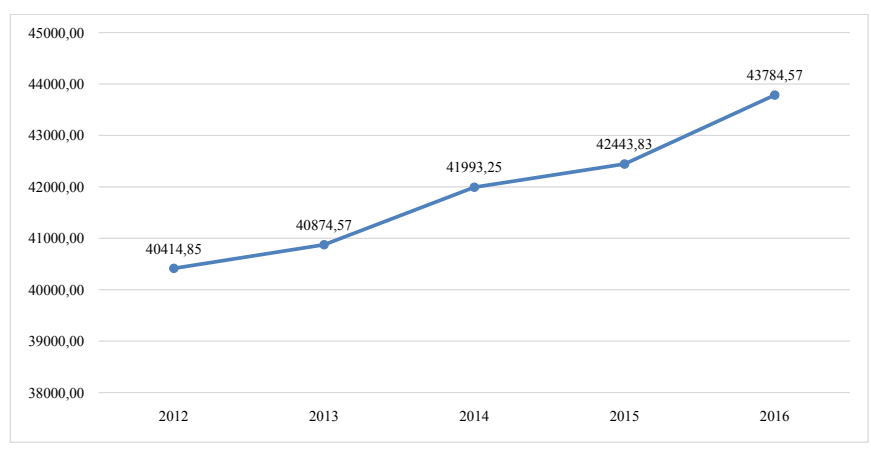

Operativni kazalnik uspešnosti podjetij EVA (5-letno povprečje) (GVIN 20 I 8b) 



\section{Priloga 5: Rezultati modeliranja s strukturnimi modeli}

Minimum was achieved

Chi-square $=133.362$

Degrees of freedom $=50$

Probability level $=.000$

\section{CMIN}

\begin{tabular}{lccccc} 
Model & NPAR & CMIN & DF & P & CMIN/DF \\
Default model & 40 & 133,362 & 50 & 0,000 & 2,667 \\
Saturated model & 90 & 0,000 & 0 & & \\
Independence model & I2 & 554,216 & 78 & 0,000 & 7,105 \\
\hline
\end{tabular}

Baseline Comparisons

\begin{tabular}{|c|c|c|c|c|c|}
\hline Model & $\begin{array}{c}\text { NFI } \\
\text { Deltai }\end{array}$ & $\begin{array}{l}\text { RFI } \\
\text { rhoI }\end{array}$ & $\begin{array}{c}\text { IFI } \\
\text { Delta2 }\end{array}$ & $\begin{array}{l}\text { TLI } \\
\text { rho2 }\end{array}$ & CFI \\
\hline Default model & 0,759 & 0,625 & 0,835 & 0,727 & 0,825 \\
\hline Saturated model & 1,000 & & 1,000 & & 1,000 \\
\hline Independence model & 0,000 & 0,000 & 0,000 & 0,000 & 0,000 \\
\hline
\end{tabular}


Strategije in uspešnost podjetja

Parsimony-Adjusted Measures

\begin{tabular}{lccc} 
Model & PRATIO & PNFI & PCFI \\
Default model & 0,641 & 0,487 & 0,529 \\
Saturated model & 0,000 & 0,000 & 0,000 \\
Independence model & 1,000 & 0,000 & 0,000 \\
\hline
\end{tabular}

NCP

\begin{tabular}{lccc} 
Model & NCP & LO 90 & HI 90 \\
Default model & 83,362 & 52,882 & 121,509 \\
Saturated model & 0,000 & 0,000 & 0,000 \\
Independence model & 476,216 & 405,247 & 554,668 \\
\hline
\end{tabular}

II 4

\section{FMIN}

\begin{tabular}{lcccc} 
Model & FMIN & Fo & LO 90 & HI 90 \\
Default model & 0,823 & 0,515 & 0,326 & 0,750 \\
Saturated model & 0,000 & 0,000 & 0,000 & 0,000 \\
Independence model & 3,421 & 2,940 & 2,502 & 3,424 \\
\hline
\end{tabular}

\section{RMSEA}

\begin{tabular}{|c|c|c|c|c|}
\hline Model & RMSEA & $\mathrm{LO}_{90}$ & $\mathrm{HI}_{90}$ & PCLOSE \\
\hline Default model & O,IOI & $0,08 \mathrm{I}$ & 0,122 & 0,000 \\
\hline Independence model & 0,194 & 0,179 & 0,210 & 0,000 \\
\hline
\end{tabular}


AIC

\begin{tabular}{|c|c|c|c|c|}
\hline Model & AIC & $\mathrm{BCC}$ & BIC & CAIC \\
\hline Default model & 213,362 & 220,342 & & \\
\hline Saturated model & 180,000 & 195,705 & & \\
\hline Independence model & 578,216 & 580,310 & & \\
\hline
\end{tabular}

\section{ECVI}

\begin{tabular}{lcccc} 
Model & ECVI & LO 90 & HI 90 & MECVI \\
Default model & I,317 & I,I29 & I,553 & 1,360 \\
Saturated model & I,III & I,III & I,III & I,208 \\
Independence model & 3,569 & 3,131 & 4,054 & 3,582 \\
\hline
\end{tabular}

HOELTER

$\begin{array}{lcc}\text { Model } & \begin{array}{c}\text { HOELTER } \\ 0,05\end{array} & \text { HOELTER } \\ 0,0 \mathrm{I}\end{array}$

Minimization: 0,022

Miscellaneous: 0,022

Bootstrap: $\quad 0,000$

Total: $\quad 0,338$ 
Strategije in uspešnost podjetja

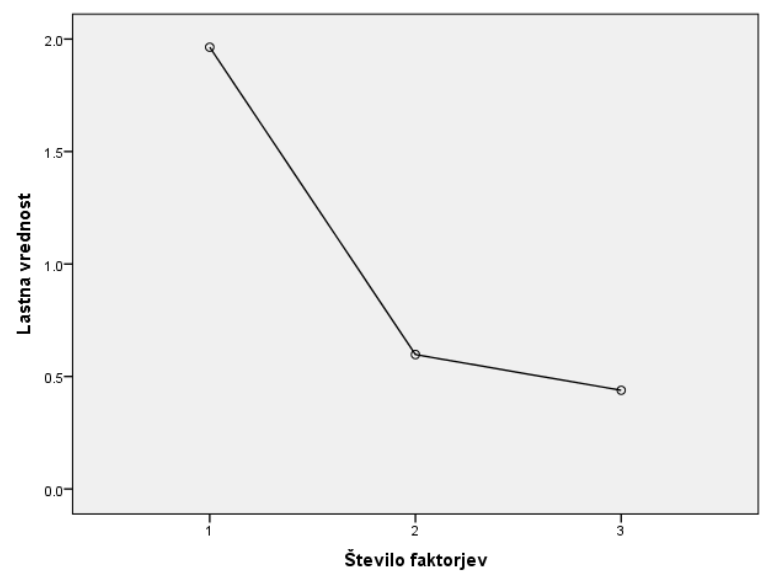

Kolenski diagram: Konkurenti

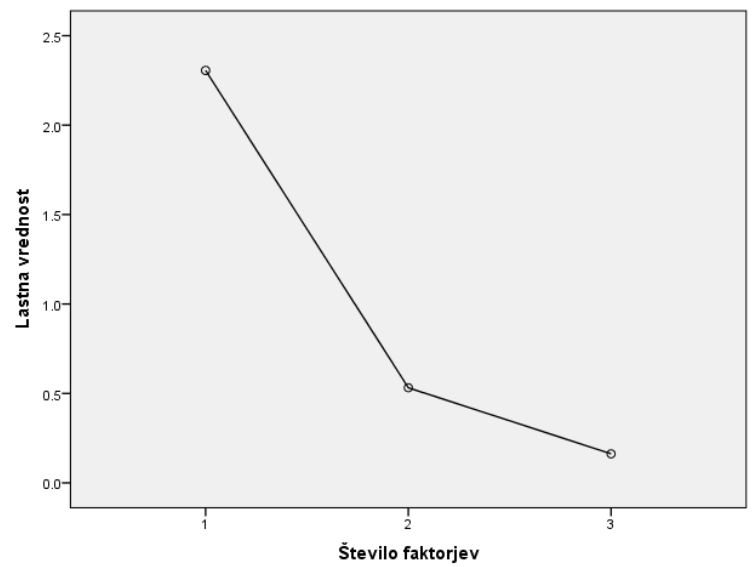

Kolenski diagram: Tehnologija 
Priloga 5: Rezultati modeliranja s strukturnimi modeli

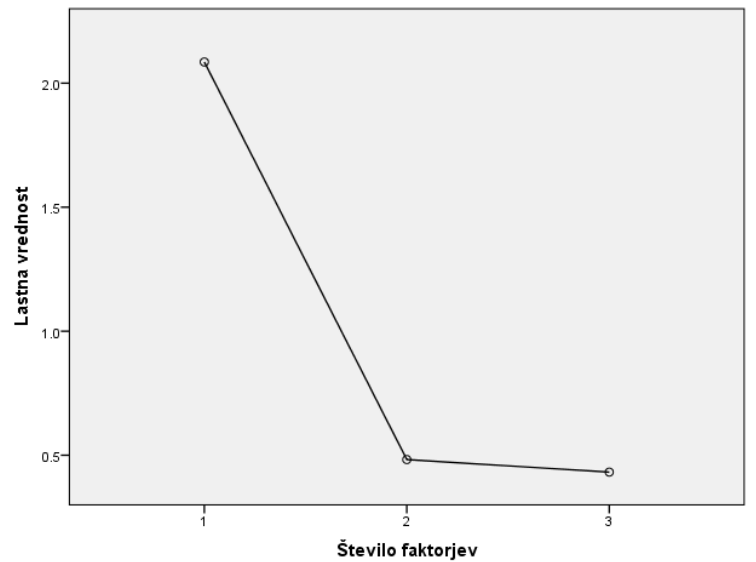

Kolenski diagram: Dobavitelji

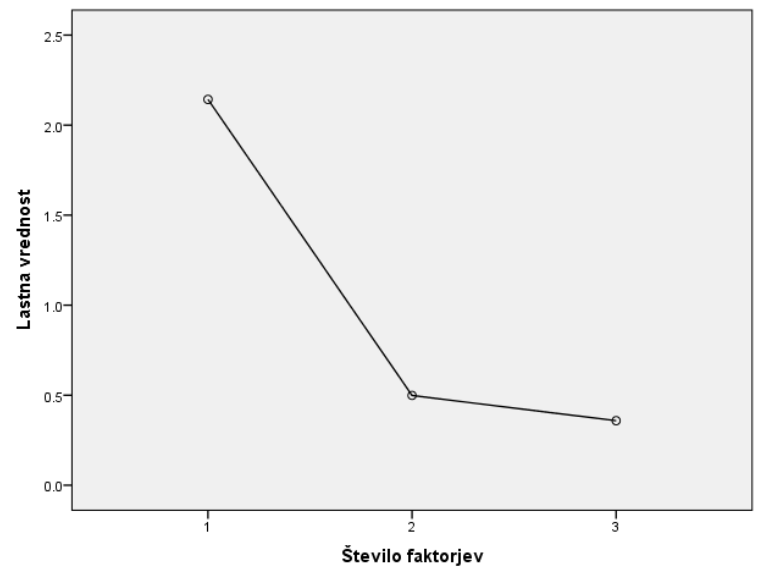

Kolenski diagram: Strategija diferenciacije 
Strategije in uspešnost podjetja

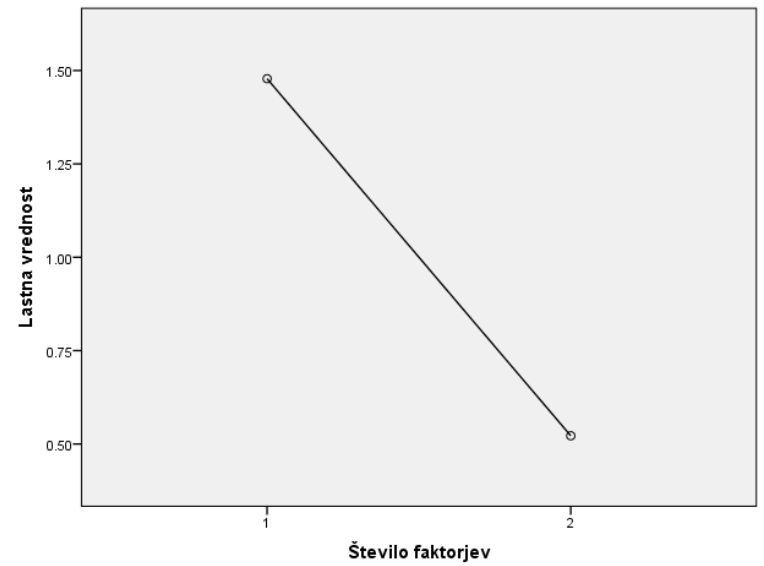

Kolenski diagram: Strategija nizki stroški in privlačne cene

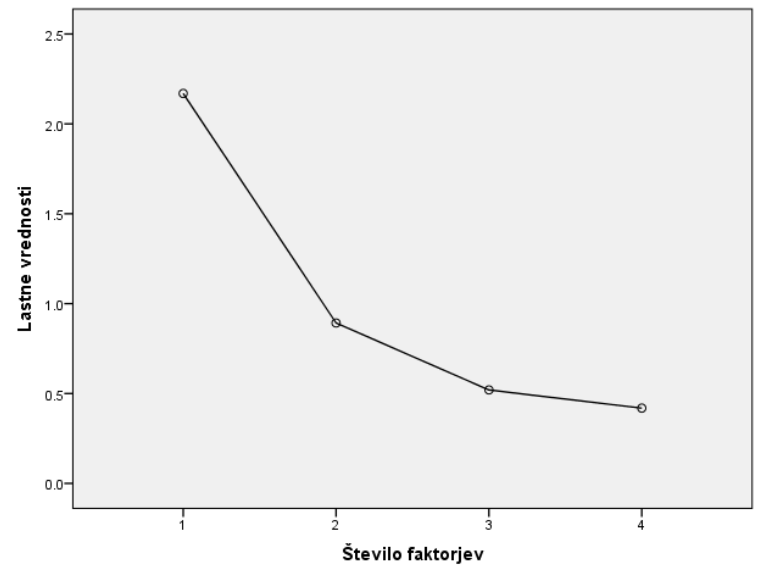

Kolenski diagram: Strategija osredinjenja 
Priloga 5: Rezultati modeliranja s strukturnimi modeli

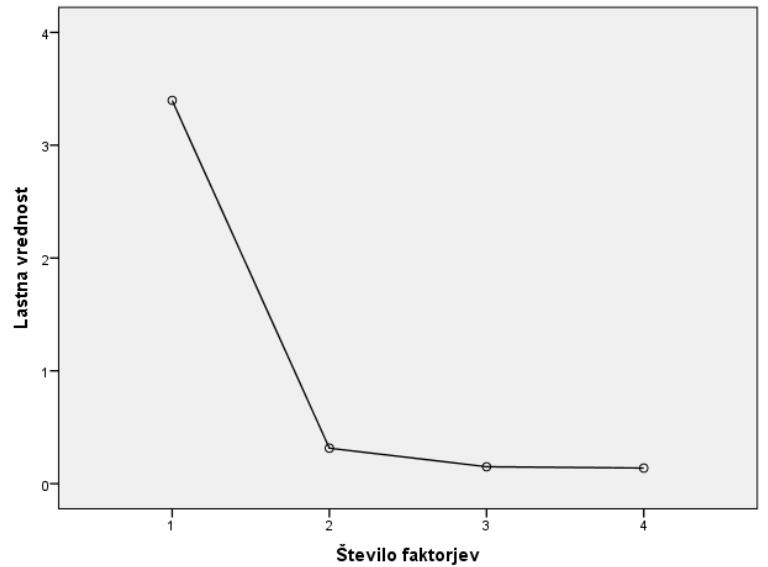

Kolenski diagram: Strategija prehitevanja 



\section{Priloga 6: Vrednosti Cronbachovih koeficientov alfa $(\alpha)$}

Interna konsistentnost za dejavnik

Kupci

Konkurenti

Tehnologija

Dobavitelji

Strategija diferenciacije

Strategija nizki stroški in privlačne cene

Strategija osredinjenja

Strategija prehitevanja
Število spremenljivk

Cronbachove vrednosti alfa $(\alpha)$

0,148

0,727

0,848

0,780

0,800

0,643

0,710

$0,94 \mathrm{I}$ 



\section{Povzetek}

Znanstveno področje $\mathrm{v}$ tej monografiji je področje strateškega managementa. Ožje področje preučevanja je raziskovanje vpliva zunanjega okolja podjetja na izbor strategije podjetja do kupcev ter vpliv na uspešnost podjetja. Na podlagi teoretičnih izhodišč iz literature smo oblikovali model povezav med izbranimi dejavniki sprememb v okolju, strategijami podjetja do kupcev in uspešnostjo podjetja. Preučevanje vplivov okolja, strategij podjetja do kupcev in njihovega vpliva na uspešnost poslovanja podjetij je kompleksno, saj na uspešnost podjetja vpliva vrsta dejavnikov, ki jih vseh hkrati v eno raziskavo ne moremo zajeti, zato povezave med izbranimi dejavniki v tej raziskavi obravnavamo kot model. V empiričnem delu smo preverili veljavnost zastavljenega modela in podali komentarje.

Raziskovalni problem v raziskavi je, kako izbrani zunanji dejavniki okolja podjetja podjetja vplivajo na strategijo podjetja do kupcev ter kako strategije nadalje vplivajo na uspešnost podjetja. $\mathrm{Na}$ osnovi spoznanj iz literature in predhodnih raziskav smo razvili hipotezo in $\mathrm{v}$ empiričnem delu preverili njeno veljavnost. Zastavljena hipoteza se glasi: »Spremembe v okolju vplivajo na izbor strategije podjetja do kupcev, kar rezultira v uspešnosti podjetja. Podjetja, ki uporabljajo strategijo diferenciacije, so uspešnejša kot tista, ki uporabljajo eno od ostalih strategij (strategijo nizkih stroškov in privlačnih cen, strategijo osredinjenja, strategijo prehitevanja).«

Za vsakega izmed dejavnikov, tj. »Spremembe v okolju « podjetja, ki vključuje področja $\gg$ Kupci $\ll, ~ \gg$ Konkurenti $\ll, ~ \gg$ Tehnologija $\ll$ in $\gg$ Dobavitelji $\ll$, in $\gg$ Strategija podjetja do kupcev«, ki vključuje področja $\gg$ Strategija diferenciacije «, »Strategija nizkih stroškov in privlačnih cen«, 
»Strategija osredinjenja « ter »Strategija prehitevanja «, smo uporabili trditve, ki so nam bile podlaga za oblikovanje anketnega vprašalnika za potrebe empiričnega dela raziskave. Merjenje uspešnosti podjetja smo glede na preučeno literaturo in vire zasnovali na celovit način, $s$ pomočjo sekundarnih podatkov o finačni uspešnosti (kazalnik donosnosti sredstev - ROA; kazalnik donosnosti kapitala - ROE), operativni uspešnosti (kazalnik ekonomske dodane vrednosti - EVA) ter kazalnik BON (bonitetna ocena poslovanja podjetja) za daljše časovno obdobje.

Ciljna populacija v raziskavi so bila majhna in srednje velika podjetja (MSP), ki so bila v času raziskave na dan I I. I. $2017 \mathrm{v}$ javni bazi podatkov o poslovnih subjektih AJPES s sedežem na območju Republike Slovenije. V raziskavo smo vključili samostojne podjetnike (s. p.), družbe z omejeno odgovornostjo (d. o. o.), družbe z neomejeno odgovornostjo (d. n. o.) in delniške družbe (d. d.). Podjetij v likvidaciji, stečaju in prisilni poravnavi nismo vključili.

Za zbiranje podatkov smo uporabili spletni anketni vprašalnik. Razvili smo ga s pomočjo pregleda literature v teoretičnem delu raziskave. Vprašalnik je sestavljen iz več sklopov. Prvi sklop obravnava dejavnike okolja in strategije, $\mathrm{v}$ drugem sklopu smo zajeli podatke o podjetju in anketirancu, zadnji sklop v vprašalniku se nanaša na ime podjetja. Potrebovali smo ga zaradi naknadnega pridobivanja aktualnih sekundarnih podatkov o ROA, ROE, EVA in BON. Sekundarne podatke smo pridobili sami iz poslovne baze GVIN za zadnjih pet let poslovanja za tista podjetja, ki so v celoti izpolnila anketni vprašalnik.

Vprašalnik je sestavljen iz vprašanj zaprtega tipa. $Z$ vidika vrste vprašanj smo vključili vprašanja o dejstvih. Anketiranci so podajali ocene strinjanja s podanimi trditvami. Uporabili smo šeststopenjsko Likertovo lestvico, da smo se izognili odgovorom na srednji vrednosti lestvice. Ordinalne spremenljivke (lestvica od I-6) smo uporabili za merjenje sprememb v okolju ter strategij podjetja do kupcev. Številske spremenljivke smo uporabili pri merjenju finančne uspešnosti podjetja, kar smo merili z ROA, ROE in EVA. Nominalne spremenljivke smo uporabili za merjenje celovite uspešnosti podjetja, kar smo merili z BON.

Vprašalnik smo oblikovali v spletni obliki s pomočjo spletne aplikacije IKA, ki je odprtokodna aplikacija za spletno anketiranje. Njegovo zanesljivost smo preverili s pomočjo Cronbachovega koeficienta alfa $(\alpha)$, veljavnost pa smo zagotovili z razvojem primernih pokazateljev za merjenje posameznih vplivov in povezav s spoznanji $\mathrm{v}$ teoretičnem delu raziskave.

Oddanih je bilo skupaj 3 I 8 anket (delno in popolno izpolnjenih). V bazi zbranih anket je ostal vzorec 163 anket podjetij s popolnimi odgovo- 
ri, vključno z imenom podjetja. Od tega je bilo 73 majhnih $(44,8 \%)$ in 90 $(55,2 \%)$ srednjih podjetij. Glede na vzorčni okvir 3.007 podjetij to predstavlja 5,42-odstotno stopnjo odzivnosti. Zbrane podatke smo s pomočjo statističnega programa SPSS (verzija 24.00) analizirali z osrednjo metodo - modeliranjem strukturnih enačb (SEM).

Rezultati preverjanja zastavljenega modela kažejo, da ta ne podaja idealnih vrednosti, kar lahko utemeljimo s tem, da (I) je naš model relativno kompleksen, saj smo zajeli relativno veliko število povezav in vplivov; (2) ocenjujemo, da bi večji vzorec lahko pripomogel $\mathrm{k}$ temu, da bi model dosegel optimalnejše vrednosti in bi tako tudi pridobil na posploševanju rezultatov; (3) merski instrument se je na področju merjenja zunanjih vplivov okolja podjetja na uspešnost pri nas izkazal za šibkega. Ocenjujemo, da bi veljavnost modela lahko izboljšali s tem, ko bi optimizirali število povezav v modelu (vključili bi manjše število vplivov) in povečali vzorec.

Na podlagi rezultatov preverjanja zastavljene hipoteze tako lahko potrdimo, da so podjetja, ki uporabljajo strategijo diferenciacije, uspešnejša kot tista, ki uporabljajo eno od ostalih ostale strategij (strategijo nizkih stroškov in privlačnih cen, strategijo osredinjenja, strategijo prehitevanja).

Rezultati kažejo, da ima strategija diferenciacije pozitiven učinek na ROA in EVA ter na BON. Podjetja bodo uspešnejša, če bodo v poslovanje vključevala vidik kupca. Statistično najznačilnejši vpliv na izbor strategije podjetja do kupcev - strategijo diferenciacije - smo ugotovili v primerih, ko podjetje sodeluje z novimi kupci, s katerimi do zdaj še ni.

Prav tako smo ugotovili, da na strategijo diferenciacije vplivajo dobavitelji kjer smo kot najvplivnejšo zaznali trditev, ki se glasi »Naši glavni dobavitelji se hitro prilagajajo spremembam v panogi«. Podjetja bodo uspešnejša, če bodo sodelovala $\mathrm{z}$ dobavitelji, ki veljajo na svojem področju za vodilne (vodje v panogi), če bodo z dobavitelji vzpostavljala dolgoročna strateška partnerstva za vzajemne koristi, če bodo dobavitelji imeli sposobnost hitrega prilagajanja na spremembe $\mathrm{v}$ panogi in če bodo podjetja konkurenčnost izdelkov/storitev dosegala s pomočjo inovativnosti svojih dobaviteljev.

Dosegli smo vse cilje raziskave:

(I) Preučili smo literaturo in vire na področju vplivov okolja na podjetja ter strategij podjetja in njihovega vpliva na uspešnost poslovanja. Naredili smo sistematičen pregled bibliografskih enot domače in tuje strokovne literature za zadnjih trideset let. Spoznanja smo vključili v teoretični del raziskave. Še zlasti smo bili pozorni na to, da smo citirali najnovejše vire in literaturo. 
(2) Zasnovali in preverili smo izvirni model povezav med izbranimi dejavniki sprememb v okolju, strategijami podjetja do kupcev in uspešnostjo podjetja. Model nam omogoča nadaljnje raziskave, poglobljene študije v Sloveniji ali primerljivih ekonomijah ter s tem odpira možnosti za doseganje novih ciljev, kar predstavljamo kot možnosti za nadaljnje raziskovanje.

(3) Izvedli smo obširno empirično raziskavo na populaciji 3.007 MSP v Republiki Sloveniji.

(4) Na podlagi rezultatov raziskave smo razvili implikacije za delo v praksi.

Ocenjujemo, da bi lahko večji vzorec pomembno vplival na rezultate te raziskave. Kot priložnost za nadaljnje raziskovanje vidimo primerjalne periodične analize na enaki populaciji in primerjalne raziskave s podobnimi ekonomijami, kot je Slovenija. 


\section{Summary}

The scientific field in this monograph is the field of strategic management. A narrower area of study explores the influence of the external environment of a company on the strategy towards customers and that impact on company performance. Based on theoretical background from the literature, we formulated a model of links between selected factors of changes in the environment, company strategies towards customers, and company performance. The study of environmental impacts, company strategies towards customers and their impact on business performance is complex because company performance is influenced by a number of factors that cannot be all captured in one study at a time, so we treated the links between these selected factors in this research as a model. In the empirical section, we checked the validity of the developed model.

The problem in this research is how selected external environmental factors related of a company affect its strategy towards customers and how these strategies further affect a company's performance. Based on the findings from the literature and previous research, we have developed a hypothesis and in the empirical part of the research checked its validity. The developed hypothesis is: Changes in the external environment of a company affect the company's strategy towards customers, which influences the performance of a company. Companies that are using a differentiation strategy have higher performance than those that are using one of the other strategies (low cost, focus, or an overtaking strategy).

For each of the factors: "Changes in the environment" of a company, which include the areas: "Customers", "Competitors", "Technology" and "Suppliers" and the factor, "Company strategy towards customers," whi- 
ch includes the following areas: "Differentiation Strategy," "Low Cost Strategy", "Focus Strategy" and "Overtaking Strategy," we used claims that formed the basis for designing the survey questionnaire for the empirical part of the research. Based on the literature and sources studied, the measurement of company performance was comprehensively designed based on secondary financial performance data (ROA, ROE), operating performance data (EVA) and business credit rating data $(\mathrm{BON})$ for an extended period of time.

The target population in our survey was small and medium-sized enterprises (SMEs), which were in the public database of business entities with headquarters in the Republic of Slovenia (AJPES) at the time of our survey on January II.I.20I7 We included sole proprietors in the research (s.p.), limited liability companies (d.o.o.), unlimited liability companies (d.n.o.) and joint-stock companies (d.d.). We did not include companies in liquidation, bankruptcy, or compulsory settlement.

We used an online questionnaire to collect the data. We developed it by reviewing the literature in the theoretical part of the research. The questionnaire had several sections. The first section addressed environmental factors and strategies; the second section captured information about the company and the respondent, while the last section in the questionnaire was to do with the name of the company. We needed it to retrieve up-to-date secondary ROA, ROE, EVA, and BON data. We obtained the secondary data ourselves from the GVIN business database for the past five years of operations for those companies that correctly filled out the survey questionnaire.

The questionnaire consisted of closed-ended questions. In terms of the nature of the questions, we included questions of fact. Respondents provided ratings of agreement with the claims made. We used a six-point Likert scale to avoid responses at the middle of the scale. An Ordinal scale (from I-6) was used to measure changes in the environment and the strategy of the company towards customers. We used numerical variables to measure the financial performance of a company, as measured by ROA, ROE, and EVA. We used nominal variables to measure the overall performance of a company, as measured by BON.

We designed the questionnaire in an online format using the web application ( $\mathrm{r} K A)$, which is an open-source web survey application. We verified the reliability of the questionnaire using the Cronbach alpha $(\alpha)$ coefficient. We ensured the validity of the questionnaire with the development of appropriate indicators for measuring individual influences and links with the findings in the theoretical part of the research. 
A total of 318 questionnaire forms were submitted (partly and fully completed). A sample of $\mathrm{I} 63$ surveyed companies with complete answers remained in the database, including the name of the company. Of those, 73 were small enterprises (44.8\%), and 90 ( $55.2 \%)$ were medium-sized enterprises. With regard to the sample framework of 3,007 companies, this represents a response rate of $5.42 \%$.

We analysed the collected data using the SPSS statistical program (version 24.00) using the central - Structural Equation Modelling method (SEM).

The verification results of the proposed model show that the model does not provide ideal values, which can be explained by the fact that (I) our model is relatively complex since we captured a relatively large number of links and influences; (2) we estimate that a larger sample could help achieve more optimal values and thus gain in the generalization of results; (3) the measuring instrument has proven to be weak in the field of measuring the external influences of a company's environment on its performance. We estimate that the validity of the model could be improved by optimizing the number of links in the model (including less influence factors) and increasing the sample size.

Based on the results of the hypothesis test, we can confirm that companies using a differentiation strategy have higher performance than those using one of the other strategies (low strategy, focus strategy, or an overtaking strategy).

The results show that a differentiation strategy has a positive effect on ROA and EVA and BON. Companies will have higher performance if they incorporate a customer perspective into their business. Statistically, the most significant influence on the choice of a company's strategy towards its customers - the differentiation strategy - was found in cases when the company cooperates with new customers with whom it has not cooperated thus far.

We have also found that suppliers influence the differentiation strategy, where we recognised the most influential claim to be "Our major suppliers are rapidly adapting to changes in the industry." Companies will have higher performance if they work with suppliers, who are leaders in their field (industry leaders), if they establish long-term strategic partnerships with them for mutual benefits, provided suppliers have the ability to quickly adapt to changes in the industry and if companies achieve product/service competitiveness through the innovation of their suppliers.

We have achieved all the goals of the research. 
(I) We have examined the literature and sources in the area of environmental impacts on companies as well as company strategies and their impact on company performance. We have conducted a systematic review of bibliographic units of domestic and foreign expert literature for the last thirty years. Our findings have been included in the theoretical part of the research. In particular, we were careful to cite the latest sources and literature.

(2) We designed and verified the original model of links with regard to the impact of changes in the external environment of a company on the company's strategy towards customers and the impact on company performance. The model enables us to carry out further research, in-depth studies in Slovenia or comparable economies, and as such, opening up the possibilities for achieving new goals, which we present as opportunities for further research.

(3) We conducted a comprehensive empirical study on a population of 3,007 SMEs in the Republic of Slovenia.

(4) Based on the results of the research, we have developed the implications for work in practice.

We estimate that a larger sample could have made a significant impact on the results of this study. As an opportunity for further research, we see periodic comparative analyses with the same population and comparative studies with similar economies like Slovenia's. 


\section{Literatura}

AJPES. B. 1. »O Ajpes: vizitka.« https://www.ajpes.si/O_AJPES/Vizitka

Allen, Richard S., in Marilyn M. Helms. 2006. »Linking Strategies and Organizational Performance to Porter’s Generic Strategies. $\ll$ Business Process Management Journal I 2 (4): 433-454.

Altman, Georg. 2003. Unternehmensfuerhung und Innovationserfolg - Eine empirische Untersuchung im Machinenbau. Wiesbaden: Deutscher Universitaets Verlag.

Alzahrani, Joman. 2019. »The Impact of E-Commerce Adoption on Business Strategy in Saudi Arabian Small and Medium Enterprises (SMEs).« Review of Economics and Political Science 4 (I): 73-88.

Angulo, Andres, Heather Nachtmann in Matthew A. Waller. 2004. »Supply Chain Information Sharing in a Vendor Managed Inventory Partnership.«Journal of Business Logistics 25 (I): IOI-I 20.

Appelbaum, Steven H., Medea Degbe Cesar, Owen O. MacDonald in Nguyen-Quang Thai-Son. 2015. »Organizational Outcomes of Leadership Style and Resistance to Change (Part Two).« Industrial and Commercial Training 47 (3): 135-I44.

Arbussa, Anna, Andrea Bikfalvi in Pilar Marques. 2017. »Strategic Agility-Driven Business Model Renewal: The Case of an SME.« Management Decision 55 (2): 27 I-293.

Arend, Richard J. 2006. »SME-Supplier Alliance Activity in Manufacturing: Contingent Benefits and Perceptions.« Strategic Management Journal 27 (8): 74I-763. 
Arend, Richard J., in Joel D. Wisner. 2005. »Small Business and Supply Chain Management: Is There a Fit? « Journal of Business Venturing 20 (3): $403-436$.

Arias, Michael, Saavedra Rodrigo, Maira R., Marques, Jorge Munoz-Gama in Marcos Sepúlveda. 2018. »Human Resource Allocation in Business Process Management and Process Mining: A Systematic Mapping Study.« Management Decision 56 (2): 376-405.

Aschhoff, Birgir, in Tobias Schmidt. 2008. »Empirical Evidence on the Success of R\&D Cooperation - Happy Together? « Review of Industrial Organization 33 (I): 4I-62.

Banker, Rajiv B., Raj Mashruwala in Arindam Tripathy. 2014. »Does Differentiation Strategy Lead to More Sustainable Financial Performance Than a Cost Leadership Strategy?« Management Decision 52 (5): $872-896$.

Bartz, Wiebke, in Adalberg Winkler. 20ı6. »Flexible or Fragile? The Growth Performance of Small and Young Businesses during the Global Financial Crisis - Evidence from Germany.« Journal of Business Venturing 3 I (2): 196-215.

Bavec, Cene, in Massimo Manzin. 2012. Strukturni vidiki organiziranosti. Koper: Fakulteta za management.

Bellamy, Lawrence Charles, Nii Amoo, Kieran Mervyn in Jacqueline Hiddlestone Mumford. 2019. »The Use of Strategy Tools and Frameworks by SMEs in the Strategy Formation Process.«International Journal of Organizational Analysis 27 (2): 337-367.

Benner, Mary J., in Michael L. Tushman. 2003. »Exploitation, Exploration, and Process Management: The Productivity Dilemma Revisited.«Academy of Management Review 28 (2): 238-256.

Bentler, Peter M., in Douglas G. Bonett. 1980. »Significance Tests and Goodness of Fit in the Analysis of Covariance Structures.« Psychological Bulletin 88 (3): 588-606.

Berends, Hans, Armand Smits, Isabelle Reymen in Ksenia Podoynitsyna. 2016. >Learning while (Re)Configuring: Business Model Innovation Processes in Established Firms.« Strategic Organization I 4 (3): I 8 I-2 I9.

Biloslavo, Roberto. 2006. Strateški management in management spreminjanja. Koper: Fakulteta za management.

Biloslavo, Roberto. 2008. Management v 2I. stoletju. Koper: Fakulteta za management.

BISNODE. B. 1. Metodologija. Ljubljana: Bisnode d. o. o. https://bonitete.bisnode.si/bonitetece/files/metodologija_si_si.pdf 
Bisogno, Stefania, Armando Calabrese, Massimo Gastaldi in Nathan Levialdi Ghiron. 20r6. \Combining Modelling and Simulation Approaches: How to Measure Performance of Business Processes.« Business Process Management Journal 22 (I): 56-74.

Bojica, Ana Maria, Maria del Mar Fuentes-Fuentes in Virginia Fernández Pérez. 2017. >Corporate Entrepreneurship and Codification of the Knowledge Acquired from Strategic Partners in SMEs.« Journal of Small Business Management 55 (I): 205-230.

Bojnec, Štefan, Žiga Čepar, Tanja Kosi in Bojan Nastav. 2007. Ekonomika podjetja. Koper: Fakulteta za management.

Bolčič, Tatjana. 1999. »Ravnanje za večanje vrednosti.« Iteo relacije Ljubljana I:IO-II.

Bretherton, Phil, in Ian Chaston. 2005. »Resource Dependency and SME Strategy: An Empirical Study.«Journal of Small Business and Enterprise Development 12 (2): 274-289.

Brouthers, Keith D., Lance E. Brouthers in Steve Werner. 2003. »Transaction Cost-Enhanced Entry Mode Choices and Firm Performance.« Strategic Management Journal 24 (I2): I239-I 248.

Buck, Trevor, Igor Filatotchev, Natalia Demina in Mike Wright. 2003. »Insider Ownership, Human Resource Strategies and Performance in a Transition Economy.« Journal of International Business Studies 34 (6): 530-549.

Burlton, Roger T. 2010. Delivering Business Strategy through Process Management: Handbook on Business Process Management 2. Heidelberg: Springer.

Calantone, Roger J., Rosana Garcia in Cornelia Droege. 2003. »The Effects of Environmental Turbulence on New Product Development Strategy Planning.«Journal of Product Innovation Management 20 (2): 90-103.

Capar, Nejat, in Masaki Kotabe. 2003. »The Relationship between International Diversification and Performance in Service Firms. «Journal of International Business Studies 34 (4): 345-355.

Capra, Fritjof. 2002. The Hidden Connections: Integrating the Biological, Cognitive, and Social Dimensions of Life into a Science of Sustainability. New York: Doubleday.

Carey, John Peter. 2015. »External Accountants' Business Advice and SME Performance.« Pacific Accounting Review 27 (2): I66-I 88.

Champy, James. 1995. Reengineering Management: The Mandate for New Leadership. London: Harper Colins.

Child, Dennis. 2006. The Essentials of Factor Analysis. London: A\&C Black. 
Crosby, Philip B. I990. Kakovost je zastonj: umetnost zagotavljanja kakovosti. Ljubljana: Gospodarski vestnik.

Danneels, Erwin, in Rajesh Sethi. 2003. »Antcendents of New Product Program Creativity: The Moderating Role of Environmental Turbulence.« Academy of Management Proceedings I. https://doi.org/10.5465/ ambpp.2003.1379326I

Davis, Paul J. 2020. »Getting Employees Involved in Strategy Planning.« Journal of Business Strategy 4I (I): 58-64.

Dawes, John. 1999. »The Relationship between Subjective and Objective Company Performance Measures in Market Orientation Research: Further Empirical Evidence.« Marketing Bulletin I0:65-76.

Delgado, Andrea, Barbara Weber, Francisco Ruiz, Ignacio Garcia-Rodriguez de Guzman in Mario Piattini. 20r4. »An Integrated Approach Based on Execution Measures for the Continuous Improvement of Business Processes Realized by Services.«Information and Software Technology $56(2): 134-162$.

De Wall, Andre. 2008. »The Secret of High Performance Organizations.« Management Online Review 2:100-108.

Dollinger, Marc J., in Peggy A. Golden. 1992. »Interorganizational and Collective Strategies in Small Firms: Environmental Effects and Performance.« Journal of Management I 8 (4): 695-7 I5.

$\gg$ Donos na kapital - ROE.«B. 1. Finančni slovar. http://www.financnislovar.com/definicije/donos-na-kapital-ROE.html

Doukas, John A., in Larry H. P. Lang. 2003. »Foreign Direct Investment, Diversification and Firm Performance.« Journal of International Business Studies 34 (2): 153-I72.

Dumas, Marlon, Macello La Rosa, Jan Mendling in Hajo A. Reijers. 2013. Fundamentals of Business Process Management. Berlin: Springer Verlag.

Easterby-Smith, Mark, Richard Thorpe in Andy Lowe. 2007. Raziskovanjev managementu. Koper: Fakulteta za management.

EFQM. 1999. The EFQM Excellence Model I999: Public and Voluntary Sector. Bruselj: EFQM.

Ensslin, Leonardo, Sandra Rolim Ensslin, Ademar Dutra, Nei Antônio Nunes in Cassiano Reis. 2017. »BPM Governance: A Literature Analysis of Performance Evaluation.«Business Process Management Journal 23 (I): $7 \mathrm{I}-86$.

Espino-Rodriguez, F. Tomas, in Manuel Rodriguez-Diaz. 2014. »Determining the Core Activities in the Order Fulfillment Process: An Empirical Application.« Business Process Management Journal 20 (I): 2-24. 
Foss, Juul N., in Tina Saebi. 2017. »Fifteen Years of Research on Business Model Innovation: How Far Have We Come, and Where Should We Go? «ournal of Management 43 (I): 200-227.

Friday, Earnest, in Shawnta S. Friday. 2003. »Managing Diversity Using a Strategic Planned Change Approach.«Journal of Management Development 22 (10): 863-880.

Garvin, David A. 1998. »The Processes of Organization and Management.« Sloan Management Review 39 (4): 33-50.

Gatignon, Hubert, in Jean-Marc Xuereb. 1997. »Strategic Orientation of the Firm and New Product Performance.«Journal of Marketing Research 34 (19): 77-90.

Ge, Gloria L., in Daniel Z. Ding. 2005. »Market Orientation, Competitive Strategy and Firm Performance: An Empirical Study of Cinese Firms.« Journal of Global Marketing I 8 (3/4): I I5-I 42.

Glavan-Milanovič, Ljubica. 20II. »Understanding Process Performance Measurement Systems.« Business Systems Research 2 (2): 1-56.

Goldsmith, Walter, in David Clutterbuck. 1984. The Winning Streak: Britain's Top Companies Reveal Their Formulas for Success. London: Weidenfield and Nicolson.

Gouardères, Frédéric. 2015. »Mala in srednja podjetja.« https://www.europarl.europa.eu/ftu/pdf/sl/FTU_2.4.2.pdf

Gruban, Brane. B. l. »Kaj je ekonomska dodana vrednost.« http:www.delavska-participacija.com/priloge/idooog23.doc

Guo, Hai, in Zhi Cao. 201 4. »Strategic Flexibility and SME Performance in an emerging Economy: A Contingency Perspective.«Journal of Organizational Change 27 (2): 273-298.

GVIN. 20I8a. $\quad \gg \mathrm{O} \quad$ podjetju.« http://www2.gvin.com/index. php/o-podjetju/vizitka-podjetja/

GVIN. 2018b. $\quad \gg$ Analizator.« http://www.gvin.com/ GvinInformator/PagesAnalizator/ Analizator. aspx ?Mode $=$ GvinSI $\&$ App $=$ GvinInformatorSI $\&$ Lang $=$ sl-SI

Hambrick, Donald C. 1983. »High Profit Strategies in mature Capital Goods Industries: A Contingency Approach.« Academy of Management Journal 26 (4): 687-707.

Harmon, Paul. 2003. Business Process Change: A Manager's Guide to Improving, Redesigning, and Automating Processes. Amsterdam: Kaufmann. 
Harmon, Paul. 2007. Business Process Change: A guide for Business and BPM Managers and Six Sigma Professionals. Burlington, VT: Morgan Kaufman.

Hauschildt, Juergen. I991. »Zur Messung des Innovaionserfolgs.« Zeitschrift fuer Betriebswirtschaft 61:45 I-476.

Heikkila, Marikka, Harry Bouwman in Jukka Heikkila. 20ı8. »From Strategic Goals to Business Model Innovation Paths: An Exploratory Study.« Journal of Small Business and Enterprise Development 25 (I): I07-I 28.

Heikkila, Marikka, Harry Bouwman, Jukka Heikkila, Sam Solaimani in Wil Janssen. 2016. »Business Model Metrics: An Open Repository.« Information Systems and E-Business Management I 4 (2): 337-366.

Hernaus, Tomislav, Vesna Bosilj Vuksic in Mojca Indihar Štemberger. 2016. >How to Go from Strategy to Results? Institutionalising BPM Governance within Organisations. B Business Process Management Journal 22 (I): $173-195$.

Hernaus, Tomislav, Mirjana Pejić Bach in Vesna Bosilj Vukšić. 2012. »Influence of Strategic Approach to BPM on Financial and Non-Financial Performance.« Baltic Journal of Management 7 (4): 376-396.

Hudson, Mel, Andi Smart in Mike Bourne. 2001. »Theory and Practice in SME Performance Measurement Systems.« International Journal of Operations \& Production Management 2 I (8): I096-I I I5.

Hult, Tomas G. M., David J. Ketchen, David A. Griffith, Brian R. Chabowski, Mary K. Hamman, Bernadine Johnson Dykes, Wesley A. Pollitte in Tamer S. Cavasugil. 2008. »An Assessment of the Measurement of Performance in International Business Research.«Journal of International Business Studies 39 (6): 1064-1080.

Isomura, Kazuhito, in Huang Pei-Yuh. 2015. »Shimamura’s Strategy to Avoid Competition: Eveloping a Low Cost Operating System and Evolutionary Manuals.« Strategic Direction 31 (5): 7-39.

Janeš, Aleksander, in Armand Faganel. 2013. »Instruments and Methods for the Integration of Company's Strategic Goals and Key Performance Indicators. Kybernetes 42 (6): 928-942.

Jaworski, Bernard J., in Ajay K. Kohli. 1993. »Market Orientation: Antcendents and Consequences.«Journal of Marketing 57 (3): 53-70.

Jeston, John, in Johan Nelis. 201 4. Business Process Management - Practical Guide to Successful Implementation. London: Routhledge.

Jiang, Bin, Gregory V. Frazier in Edmund L.Prater. 2006. »Outsourcing Effects on Firms Operational Performance: An Empirical Study.« In- 
ternational Journal of Operations and Production Management 26 (I2): I $280-1300$.

Kabale, Edward, in Geoffrey Mayoka Kituyi. 2015. »A Theoretical Framework for Requirements Engineering and Process Improvement in Small and Medium Software Companies.«Business Process Management Journal 2 I (I): 80-99.

Kaplan, Robert S., in David P. Norton. 1996. The Balanced Score Card: Translating Strategy into Action. Boston: Harvard Business School.

Kaplan, Robert S., in David P. Norton. 2000. Uravnoteženi sistem kazalnikov. Ljubljana: Gospodarski vestnik.

Kavčič, Klemen. 2009. Zunanje izvajanje dejavnosti: analiza slovenskih podjetij. Koper: Fakulteta za management.

Kennerley, Mike, in Andy Neely. 2003. »Measuring Performance in a Changing Business Environment.«International Journal of Operations \& Production management 23 (2): 213-229.

Keong, Kwee Choong. 2013. »Understanding the Features of Performance Measurement System: A Literature Review.« Measuring Business Excellence $\mathrm{I} 7$ (4): IO2-I2I.

Keong, Kwee Choong. 2014. »The Fundamentals of Performance Measurements. « International Journal of Productivity and Performance Management 63 (7): 879-922.

Kim, Chan W., in Rene Mauborgne. 2005. Blue Ocean Strategy. Boston, MA: Harvard Business School.

Kim, Eonsoo, Dae Il Nam in Larry L. Stimpert. 2004. »Testing the Applicability of Porter's Generic Strategies in the Digital Age: A Study of Korean Cyber Malls.«Journal of Business Stategies 2 I (I): 19-45.

Kirca, Ahmet H., Satish Jayachandran, in Wiliam O. Bearden. 2005. »Market Orientaton: A Meta-Analytic Review and Assessment of Its Antecedents and Impact on Performance.«Journal of Marketing 69 (2): 24-4I.

Kondaskar, Yogesh. 2014, 2. oktober. »How to Cope with Resistance to BPM Projects.« BPM Leader. http://www.bpmleader.com/2014/10/02/ how-to-deal-with-resistance-to-bpm-projects/

Koo, Chul Mo, Chang E. Koh in Kichan Nam. 2004. »An Examination of Porters Competitive Strategies in Electronic Virtual Markets: A Comparison of Two On-Line Business Models.« International Journal of Electronic Commerce 9 (I): 163-80.

Košmelj, Katarina. 200ı. »Osnove logistične regresije (2. del).« Acta agriculturae Slovenica 77 (2): 239-245. 
Kotabe, Masaaki, Srinivasan Srini in Pret S. Aulakh. 2002. \Multinationality and Firm Performance: The Moderating Role of R\&D and Marketing Capabilities.« Journal of International Business Studies 33 (I): 79-97.

Kralj, Janko. 2003. Management: temelji managementa, odločanje in ostale naloge managerjev. Koper: Fakulteta za management.

Kumar, Ravinder, in Rajesh Kumar Singh. 2017. »Coordination and Responsiveness Issues in SME Supply Chains: A Review.«Benchmarking: An International Journal 24 (3): 635-650.

Lau, Henry, Dilupa Nakandala, Premeratne Samaranayake in Paul K. Shum. 2016. »BPM for Supporting Customer Relationship and Profit Decision.« Business Process Management Journal 22 (I): 23 I-255.

Laudien, Sven M., in Birgit Daxböck. 2017. »Business Model Innovation Processes of Average Market Players: A Qualitative-Empirical Analysis.«R RUD Management 47 (3): 420-430.

Liao, Suqin, Lihua Fu in Zhiying Liu. 2020. »Investigating Open Innovation Strategies and Firm Performance: The Moderating Role of Technological Capability and Market Information Management Capability.« Journal of Business \& Industrial Marketing 35 (I): 23-39.

Li, Tiger, in Roger J. Calantone. 1998. »The Impact of Market Knowledge Competence on New Product Advantage: Conceptualization and Empirical Examination.«Journal of Marketing 62 (4): 13-29.

Ljungberg, Anders. 2002. »Process Measurement.« International Journal of Physical Distribution \& Logistics Management 32 (4): 254-287.

Margherita, Alessandro. 2014. »Business Process Management System and Activities.« Business Process Management Journal 20 (5): 642-662.

Markič, Mirko. 2003. »Inoviranje procesov kot pogoj za odličnost poslovanja.« Doktorska disertacija, Univerza v Mariboru.

Mulej, Matjaž, Espejo Raul, Jackson C. Michael, Kajzer Štefan, Mingers John, Mlakar Peter, Mulej Nastja, Potočan Vojko, Rebernik Miroslav, Rosicky Antonin, Schiemenz Bernd, Umpleby A. Stuart, Uršič Duško in Renaud Vallee. 2000. Dialektična in druge mehkosistemske analize. Maribor: Ekonomsko-poslovna fakulteta.

Nandakumar, Mankavil Kovil, Abby Ghobadian in Nicholas O'Regan. 2009. \Generic Strategies and Performance - Evidence from Manufacturing Firms.«International Journal of Productivity 60 (3): 222-25 I.

Niehaves, Bjoern, Jens Poeppelbuss, Ralf Plattfaut in Joerg Becker. 2014. »BPM Capability Development - A Matter of Contingencies.« Business Process Management Journal 20 (I): 90-106. 
Parnell, John A. 2006. »Generic Strategies after Two Decades: A Reconceptualization of Competitive Strategy.« Management Decision 44 (8): I I39-II54.

Peronja, Ivan. 2015. »Performance Effects of the Business Process Change in Large Enterprises: Case of Croatia.« Management 20 (I): I-22.

Porter, Michael E. 1980. Competitive Strategy - Techniques for Analyzing Industries and Competitors. New York: The Free Press.

Potočan, Vojko, in Zlatko Nedelko. 2015. Poslovni procesi v organizacijah. Maribor: samozaložba.

Prahalad, Krishnarao C., in Garry Hamel. 1990. »The Core Competence of the Corporation.« Harvard Business Review 68 (3): 79-71.

Pučko, Daniel. 2003. Strateško upravljanje. Ljubljana: Ekonomska fakulteta.

Reuer, Jefrey J., in Tony W. Tong. 2007. »How Do Real Options Matter? Empirical Research on Strategic Investments and Firm Performance.« Advances in Strategic Management 24:145-173.

Rezaei, Jafar, Roland Ortt in Paul Trott. 2015. »How SMEs Can Benefit from Supply Chain Partnerships.« International Journal of Production Research 53 (5): 1527-I543.

Rezaei, Jafar, Roland Ortt in Paul Trott. 20 18. »Supply Chain Drivers, Partnerships and Performance of High-Tech SMEs: An Empirical Study Using SEM.« International Journal of Productivity and Performance Management 67 (4): 629-653.

Rowell, James. 2018. \Do Organisations Have a Mission for Mapping Processes? « Business Process Management Journal 24 (I): $2-22$.

Schwab, Klaus. 2016. Četrta industrijska revolucija. Ženeva: World Economic Forum.

Shan-Huei, Wang, Chung-Jen Chen, Ruey-Shan Guo, Andy Ruey-Shan Guo in Ya-Hui Lin. 2020. »Strategy, Capabilities, and Business Group Performance: The Endogenous Role of Industry Diversification.« $\mathrm{Ma}$ nagement Decision 58 (I): 76-97.

Signoretti, Andrea. 2020. »Overcoming the Barriers to the Implementation of More Efficient Productive Strategies in Small Enterprises.« Employee Relations 42 (I): I 49-165.

Sinur, Jim, James Odell in Peter Fingar. 2013. Business Process Management: The Next Wave. Tampa, FL: Meghan-Kiffer.

Slovar slovenskega knjižnega jezika. B. 1. http://bos.zrc-sazu.si/cgi/aoz. exe?name $=$ sskj_testa\&expression $=$ proces $\&$ hs $=\mathrm{I}$ 
Slovenska tiskovna agencija. 2016, 24. november. »Koleša: Stanje malih in srednjih podjetij ni optimalno, a trendi so pozitivni.« https://krog.sta. si/2328297/kolesa-stanje-malih-in-srednjih-podjetij-ni-optimalno-a-trendi-so-pozitivni

Smith, Howard, in Peter Fingar. 2003. Business Process Management: The Third Wawe. Tampa, FL: Meghan-Kiffer Press.

Statistični urad Repubike Slovenije. 2010. Standardna klasifikacija dejavnosti 2008. Klasifikacije št. I I. Ljubljana: SURS. http://www.stat.si/doc/ pub/skd.pdf

Statistični urad Republike Slovenija. 2017, 28. november. »V 2016 poslovalo I96.072 podjetij. « http://www.stat.si/StatWeb/News/Index/7063

Stonehouse, George H., in Jonathan D. Pemberton. 2005. Learning to Become a Knowledge-Centric Organisation. Hershey, PA: Information Science.

Stonehouse, George H., in Brian Snowdon. 2007. »Competitive Advantage Revisited: Michael Porter on Strategy and Competitiveness.«Journal of Management Inquiry I 6 (3): 256-273.

Stonehouse, George H., Pemberton Jonathan D. in Claire E. Barber. 200 I. »The Role of Knowledge Facilitators and Inhibitors: Lessons from Airline Reservations Systems.« Long Range Planning 34 (2): I I5-I38.

Strecker, Nanja. 2009. Innovation Strategy and Firm Performance. Wiesbaden: GWV Fachverlage GmbH.

Tangen, Stefan. 2005. »Improving the Performance of a Performance Measure.« Measuring Business Excellence 9 (2): 4-I I.

Taticchi, Paolo, Flavio Tonelli in Luca Cagnazzo. 2010. »Performance Measuremement and Management: A Literature Review and a Research Agenda.«Measuring Business Excellence I 4 (I): 4-1 8.

Tavakol, Mohsen, in Reg Dennick. 20I . »Making Sense of Cronbach's Alpha.«International Journal of Medical Education 2:53-55.

Tavčar, Mitja I. 2009. Management in organizacija: sinteza konceptov organizacije kot instrumenta in kot skupnosti interesov. Koper: Fakulteta za management.

Thakkar, Jitesh, Arun Kanda in S. G. Deshmukh. 201 2. »Supply Chain Issues in Indian Manufacturing SMEs: Insights from Six Case Studies.« Journal of Manufacturing Technology Management 23 (5): 634-664.

Thennakoon, Dharshani, Wasana Bandara, Erika French in Paul Mathiesen. 2018. »What Do We Know about Business Process Management Training? Current Status of Related Research and a Way Forward.« Business Process Management Journal 24 (2): 478-500. 
Trkman, Peter, Marko Budler in Aleš Groznik. 2015. »A Business Model Approach to Supply Chain Management.« Supply Chain Management An International Journal 20 (6): 587-602.

Trkman, Peter, Willem Mertens, Stijn Viaene in Paul Gemmel. 2015. »From Business Process Management to Customer Process Management. $\mathrm{Bu}$ siness Process Management Journal 2 I (2): 250-266.

Tucker, Leynard R., in Charles Lewis. 1973. »A Reliability Coefficient for Maximum Likelihood Factor Analysis.«Psychometrika 38 (I): I-IO.

Tucker, Ledyard R., in Robert C. MacCallum. 1997. Exploratory Factor Analysis. Neobjavljeni rokopis. Columbus, OH: Ohio State University Press.

Tupa, Jiri. 2010. Process Performance Measurement as Part of Business Process Management. http://www.intechopen.com/books/process-management/process-performance-measurementas- part-of-business-process-management-in-manufacturing-area

Unterlechner, Marko, Zlatka Meško Štok in Mirko Markič. 2009. Inoviranje, kakovost in Lean Six Sigma v proizvodnem procesu. Koper: Fakulteta za management.

Vasquez, Rodolfo, Maria Leticia Santos in Luis Ignacio Alvares. 200I. >Market Orientation, Innovation and Competitive Strategies in Industrial Firms.«Journal of Strategic Marketing 9 (I): 69-90.

Vom Brocke, Jan, Theresa Schmiedel, Jan Recker, Peter Trkman, Wilem Mertens in Stijn Viaene. 20 I 4. »Ten Principles of Good Business Process Management.« Business Process Management Journal 20 (4): 530-548.

Vujoševič, Niko. I992. Sistemi kakovosti po ISO gooo: smernice za zgradbo sistemovkakovosti. Ljubljana: Gospodarski vestnik.

Wagner, Richard, in Robert A. Paton. 20I4. »Strategic Toolkits Practice and Performance: A German SME Perspective.« The Journal of Information and Knowledge Management Systems 44 (4): 470-495.

Wiengarten, Frank, Huashan Li, Prakash J. Singh in Brian Fynes. 2019. $\gg$ Re-Evaluating Supply Chain Integration and Firm Performance: Linking Operations Strategy to Supply Chain Strategy. $\ll$ Supply Chain Management 24 (4): 540-559.

Wurthmann, Kurt. 2020. »The Essential Mix: Six Tools for Strategy-Making in the Next Decade.« Journal of Business Strategy 4I (I): 38-49.

Yong, An Gie, in Sean Pearce. 2013. »A Beginners Guide to Factor Analysis: Focusing on Exploratory Factor Analysis.« Tutorials in Quantitative Methods for Psychology 9 (2): 79-94. 
Strategije in uspešnost podjetja

Zahra, Shaker A., in Jefrey Covin. 1993. »Business Strategy, Technology Policy and Firm Performance.« Strategic Management Journal I 4 (6): $45 \mathrm{I}-478$.

»Zakon o gospodarskih družbah (ZGD-1).« 2006. Uradni list $R S$, št.42/2006. https://www.uradni-list.si/glasilo-uradni-list-rs/ vsebina?urlurid $=20061799$

Zhou, Kevin Zheng, Bennet C. K. Yim in David K. C. Tse. 2005. »The Effects of Strategic Orientation in Technology - And Market-Based Breakthrough Innovations.«Journal of Marketing 69 (4): 42-60. 


\section{Recenziji}

Znanstvena monografija Strategije in uspešnost podjetja avtorja dr. Dušana Gošnika jeizvirno znanstveno delo s področja managementa, ki ponuja vrsto metodoloških in vsebinskihnovosti tako s slovenskega kot mednarodnega vidika. Monografija predstavlja empiričnoraziskavo, s katero avtor potrjuje hipotezo, da so podjetja, ki uporabljajo strategijo diferenciacije, uspešnejša kot tista, ki uporabljajo eno od ostalih strategij, kot so strategija nizkih stroškov in privlačnih cen, strategija osredinjenja in strategija prehitevanja.

Prvi del monografije opisuje teoretične osnove, na katerih temelji raziskava. To so predvsemdefinicija uspešnosti podjetja, izbor zunanjih dejavnikov, ki vplivajo na uspešnost podjetja, terrazlične strategije, povezane s kupci. Avtor predstavlja tudi lasten teoretičen model povezav med omenjenimi dejavniki ter na njem zasnovano raziskovalno hipotezo. V drugem delumonografije pa predstavlja potek in rezultate empirične raziskave, ki jo je opravil na vzorcu3.007 majhnih in srednje velikih podjetij v Sloveniji, ki so bila v času raziskave $\mathrm{v}$ javni bazipodatkov o poslovnih subjektih (AJPES). Raziskava je bila opravljena preko spletnega vprašalnika.

Zbrani podatki so bili statistično analizirani z uporabo paketa SPSS (korelacijska analiza,multipla regresijska analiza, modeliranje strukturnih enačb - SEM ter eksplorativna faktorskaanaliza). Avtor se je naslonil obsežen izbor različnih statističnih testov in ocen, ki so muomogočili podrobno in vsebinsko poglobljeno interpretacijo rezultatov. V zaključ- 
ku avtorpoda sintezo svojih ugotovitev ter napotke za uporabo raziskovalnih rezultatov $v$ praksi.Struktura monografije je ustrezna in odraža znanstveno naravo dela. To velja tudi za izbor tujein domače literature ter znanstveno in strokovno izrazje.

\section{Cene Bavec}

\section{II}

Znanstvena monografija Strategije in uspeřnost podjetja avtorja dr. Dušana Gošnika se osredotoča na aktualno tematiko strateškega managementa s poudarkom na vplivih okolja na strategije podjetja ter njihovem vplivu na uspešnost podjetij. Povezave med okoljem, strategijami in uspešnostjo podjetja obravnava kot konceptualni model.

Avtor celostno predstavi pomen sprememb v okolju za zasnovo strategije podjetja. Zunanje okolje analizira celovito na področju kupcev, dobaviteljev, konkurentov in tehnologije. Pri tem za vsak dejavnik obširno predstavi ugotovitve predhodnih raziskav na tem področju. V nadaljevanju predstavi pomen in vrste strategij podjetja do kupcev in jih poveže $\mathrm{z}$ uspešnostjo podjetja. Zastavil je izvirni konceptualni model povezav med spremembami v okolju, strategijami podjetja ter uspešnostjo podjetja.

Na populaciji 3.007 slovenskih majhnih in srednje velikih podjetij je zasnoval in izvedel empirično raziskavo o vplivih managementa temeljnih procesov na uspešnost podjetij. Skozi empirični del monografije ugotavlja odnose med spremembami v okolju, strategijami podjetja do kupcev ter uspešnostjo podjetij.

Iz upoštevanih virov je razvidno, da je avtor celovito analiziral obravnavano področje. $\mathrm{V}$ monografijo je vključenih veliko aktualnih virov iz mednarodnih podatkovnih baz ter mednarodnih raziskav s področja strategij in uspešnosti podjetij, s katerimi avtor ugotovitve lastne raziskave tudi podkrepi.

Poglavja monografije so ustrezno razvrščena, pregledna in znanstveno utemeljena. Prav tako sta struktura monografije in metodologija raziskovanja, s katero je avtor prišel do novih spoznanj, zastavljena na ustrezen način. Avtor v eksaktnem in slogovno dobro izdelanem zaključnem poglavju poda sintezo ugotovitev glede na zastavljen model raziskave in razvije implikacije za delo v praksi.

Zato monografija, ki temelji na konceptualnem modelu ter empiričnem raziskovanju, prinaša svežino na področju raziskovanja vpliva zuna- 
njih dejavnikov okolja in strategij podjetja do kupcev na uspešnost podjetij tako v slovenskem kot v mednarodnem merilu.

Aljaž Stare 


$$
8
$$

